\title{
IV The Parable of the Pearl and its Interpretations
}

\section{Maimonides's Parable of the Pearl and Abulafia's Or ha- Śekhel}

Taking into serious consideration Abulafia's Neo-Aristotelian framework-which harboured both a radical anthropology and a radical theory about sacred texts (which, distinct from double-faith theory, ${ }^{1}$ is similar to double-truth theory)-and his use of multi-layered esotericism, ${ }^{2}$ I will now analyse his understanding of a special modified version of the well-known parable of the three rings. This parable, which deals with the nature of religion, is not found in traditional Jewish sources.

In this book, I have argued that Abulafia utilises something similar to a universal approach in his interpretation of sacred texts. In this chapter, I seek to take this theory from the more general level of observation and discussion to an analysis of a concrete subject that can be better understood by attributing a much greater role to Abulafia's Maimonidean background. Although political esotericism, in my opinion, underlies the content and context of Abulafia's analysis of the parable of the pearl, I will show that a more redemptive and personal form of esotericism is also present. However, let me first address a concept that is fundamental in the medieval version of the parable of the pearl.

As found in the introduction to this book, a careful reader and teacher of The Guide of the Perplexed, as Abulafia presents himself to be, could hardly be ignorant of Maimonides's parable of the lost pearl. Dedicated to a new emphasis on the paramount role of cognition, Maimonides refers to the use of parables by Solomon, the wisest of all men, as understood in the Midrash on the Song of Songs. He writes:

Rather what this text has in view here is, without any doubt, the understanding of obscure matters. About this, it has been said: Our Rabbis say ${ }^{3}$ a man who loses a sela or a pearl in his house can find the pearl by lightning a taper worth an issar. In the same way, this parable in itself is worth nothing, but by means of it, you can understand the words of the Torah. ${ }^{4}$ This too is literally what they say. Now consider the explicit affirmation of [the sages] [...] that the internal meaning of the words of the Torah is a pearl, whereas the external meaning of all parables is worth nothing, and their comparison is of the concealment of a subject by its parable's external

1 See Harry A. Wolfson, “The Double Faith Theory in Saadia, Averroes and St. Thomas," in Studies in the History of Philosophy and Religion, eds. Isadore Twersky and George H. Williams (Cambridge, MA: Harvard University Press, 1973): 1:583-618, and Alain de Libera, Penser au Moyen Age (Paris: Seuil, 1991), 122-39.

2 In addition to Maimonidean political esotericism, Abulafia was well-acquainted with Abraham ibn Ezra's astrological esotericism. Although Abulafia was interested in astro-magic, there are relatively few vestiges of ibn Ezra's esotericism in his writings. The fear of Christian persecution is mentioned once as a reason for hiding his views. See Idel, Studies in Ecstatic Kabbalah, 54-55.

3 I am not aware of the existence of a Rabbinic parable like this.

4 Midrash of Song of Songs 1:1.

2 OpenAccess. (c) 2020, Moshe Idel, published by De Gruyter. (c) BY-NC-ND This work is licensed under the

Creative Commons Attribution-NonCommercial-NoDerivatives 4.0 License.

https://doi.org/10.1515/9783110599978-004 
meaning to a man who let a pearl drop in his house, which was dark and full of furniture. Now this pearl is there, but he does not see it and does not know where it is. It is as though it were no longer in his possession, as it is impossible for him to derive any benefit from it until [...] he lights a lamp-an act which corresponds to an understanding of the meaning of the parable. ${ }^{5}$

From the point of view of our discussion here, the sharp distinction between the parable itself (which is considered worthless) and its interior meaning (which is the only thing that counts from an intellectual point of view) is of paramount importance. Parables in general are not the subject matter under discussion, but rather only the parables found in the sacred scriptures. This passage, therefore, goes further than simply providing an implicit critique of the plain sense of the Bible. The plain sense is compared to a darkness within which there is a precious and luminous pearl. Interpretation consists in illumining the darkness (i.e., the opaque parable) in order to find the lost pearl. As such, the Bible itself is not criticised, but only its plain sense.

Although it is quite plausible that Abulafia was acquainted with this passage from Maimonides's famous text, I have not found any direct references to it in his writings. Nevertheless, it seems that in the introduction to his book Or ha-Śekhel, whose title means "the light of the intellect," we find a very similar image; in this case, an image of the light of the sun that illumines a dark house so that it is possible to see what can be found within. Abulafia, following Aristotle, ${ }^{6}$ compares this image to the impact of the illumination of the intellect, explicitly referencing the tenth separate intellect (the Agent Intellect) in this context. ${ }^{7}$ In his description of his own illumination in Barcelona, he speaks about light penetrating through windows. ${ }^{8}$ No doubt these images stem from the vast reservoir of imagery found in the Platonic

5 Pines, Guide of the Perplexed, 1:11. This passage is discussed in Levi ben Abraham, Liwyat Hen, Ma'aśeh Berešit, 38-39. It was also interpreted in the fourteenth-century Yemenite commentary by Zerahyyah ha-Rofe' discussed by Yitzhak Tzvi Langermann, "Sharh Al-Dalala: A Commentary to Maimonides's Guide from Fourteenth-Century Yemen," in Traditions of Maimonideanism, ed. Carlos Fraenkel (Leiden: Brill, 2009): 160-61. See Joseph Stern, Problems and Parables of Law: Maimonides and Nahmanides on Reasons for the Commandments (Ța'amei Ha-Mitzvot) (Albany, NY: SUNY Press, 1998), 7; Stern, The Matter and Form of Maimonides's Guide, 26-28, 53, 61; see also the different position of Lawrence Kaplan, "The Purpose of the Guide of the Perplexed, Maimonides's Theory of Parables, and Sceptical versus Dogmatic Readings of the Guide," in Scepticism and Anti-Scepticism in Medieval Jewish Philosophy and Thought, ed. Racheli Haliva (Berlin: De Gruyter, 2018): 67-85, and Diamond, Maimonides and the Hermeneutics of Concealment, 13-20.

6 De Anima 3.5.430a16.

7 Or ha-Śekhel, 2-3. For the resort to the phrase Or ha-Śekhel in the poem that concludes the introduction, see page 4, where there is an error in the print (מאור שכל instead of שכוד).

8 See the texts presented in Idel, "Sefer Yetzirah and Its Commentaries," 478, and Oșar 'Eden Ganuz, 3:10, 367 . 
and Aristotelian traditions-they reverberate in innumerable texts in the Middle Ages, including many Jewish ones. ${ }^{9}$

This is just one example of the large-scale resort to Maimonidean images, parables, and terms that permeates Abulafia's writings. Unquestionably, the Maimonidean literature is the main source of the technical terminology that is dominant in all of his writings. An example of this utilisation of Maimonidean literature can be found in the manner in which Abulafia describes the definition of prophecy, which was a major topic in his religious worldview. ${ }^{10}$ Though at the same time drawing from a very opposite intellectual trajectory, as Abulafia was part of the Maimonidean camp, it is evident that his thought is also grounded in Sefer Yeșirah, a book never mentioned by Maimonides himself. Abulafia's conceptual apparatus is dominantly Neo-Aristotelian, while the other sources (Neo-Platonic, Pythagorean, Hermetic, or theosophical), though sometimes evident in his writings, are nevertheless marginal. In some cases, their meaning is substantially qualified by the Neo-Aristotelian matrix. However, while Maimonides's parable assumes a hidden message that is quite definite in Abulafia, it is less a matter of discovering the secret meaning of the text and more, though not exclusively, a matter of an interpreter inserting meaning into a text, which a modern thinker will see as eisegesis. With these observations in mind, I will now give a detailed analysis of a parable found in one of Abulafia's major writings.

\section{Abraham Abulafia's Version of the Pearl Parable}

There is scarcely a single passage in Abulafia's numerous writings that has received scholarly attention equal to that of his account of the parable of the son and the pearl. Since the second half of the nineteenth century, this parable has been dealt

\footnotetext{
9 See Alexander Altmann, "Ibn Bajja on Man's Ultimate Felicity," in Harry Austryn Wolfson: Jubilee Volume on the Occasion of his Seventy-Fifth Birthday, eds. Arthur Hyman, Saul Liberman, Shalom Spiegel, and Leo Strauss (Jerusalem: American Academy for Jewish Research, 1965): 1:60-64; Franz Rosenthal, Knowledge Triumphant: The Concept of Knowledge in Medieval Islam (Leiden: Brill, 1970), 155-92; and Van den Bergh, Averroes’ Tahāfut al-Tahāfut, §29. On light in Abulafia, see my The Mystical Experience, 77-83; “From 'Or Ganuz' to 'Or Torah': A Chapter in the Phenomenology of Jewish Mysticism” [Hebrew], Migwan De'ot be-Yiśra'el 11 (2002): 37-46; and my introduction to Le Porte della Giustizia, 165-200. For Abulafia's reference to this image, see Hayyei ha-Nefeš, 154-55, 158. On mysticism more generally, see Matthew T. Kapstein, ed., The Presence of Light: Divine Radiance and Religious Experience (Chicago: University of Chicago Press, 2004); Mircea Eliade, The Two and the One, trans. J.M. Cohen (New York: Harper \& Row, 1969), 19-77; Edwyn Bevan, Symbolism and Belief (Boston: Beacon Press, 1957), 125-50; and Max Pulver, "The Experience of Light in the Gospel of St. John, in the 'Corpus Hermeticum,' in Gnosticism, and in the Eastern Church," in Spiritual Disciplines: Papers from the Eranos Yearbooks, ed. Joseph Campbell (Princeton: Princeton University Press, 1960), 239-66.

10 See Idel, "Definitions of Prophecy: Maimonides and Abulafia."
} 
with by a variety of scholars, each for his or her own reason; however, no sustained analysis of its context and the author's intention is available. ${ }^{11}$ This parallel to the more famous parable of the three sons and the three rings appears in Or ha-Śekhel (ca. 1282-83), ${ }^{12}$ one of the earliest books Abulafia wrote during his stay in Messina in his most productive decade (ca. 1281-91).

In this chapter and the two following ones, I will concentrate on Abulafia's version of the three rings parable and its scholarly interpretations, leaving aside other versions in the Jewish tradition that focus on the more common variants of it. In order to provide an adequate analysis of Abulafia's version, I have produced a critical edition and translation of the entire chapter that contains the parable in Appendix A. In the present chapter, I will provide a detailed comparison to other discussions found in Or ha-Śekhel, as well as Abulafia's other treatises. I seek to avoid discussions grounded in small fragments taken out of context, a phenomenon that invites eventual misunderstandings. This approach, which attempts to make sense of a larger passage by Abulafia and not only short excerpts, has already been applied in my analysis of a passage that includes Abulafia's list of twelve commentaries on Sefer Yeșirah. ${ }^{13}$ It allows for a much more detailed confrontation with his thought and sources, as seen above in the case of his testimony of his teaching of the Guide.

Most of the scholars who have analysed Abulafia's version of the parable have been less concerned with the specific conceptual framework in which it is embedded

11 The core of the story can be found in Muslim sources. See Louis Massignon, "La legende de Tribus Impostoribus et ses origines Islamiques," in his Opera Minora, 1:82-85, and Barbara Roggema, Marcel Poorthuis, and Pim Valkenberg, eds., The Three Rings: Textual Studies in the Historical Trialogue of Judaism, Christianity, and Islam (Leuven: Peeters, 2005), 279-81. For a bibliography, see Iris Shagrir, “The Parable of the Three Rings: A Revision of Its History," Journal of Medieval History 23, no. 2 (1997): 163-77, especially 171-72 and 175-77, and now her The Parable of the Three Rings and the Idea of Religious Toleration in Premodern European Culture [Hebrew] (Jerusalem: Magnes Press, 2017), passim, especially 37-42. For Abulafia’s special version, see Moritz Steinschneider, Hebraeische Bibliographie, vol. 4 (Berlin: Asher, 1861): 78, note 7; Moritz Steinschneider, Hebraeische Bibliographie, vol. 12 (Berlin: Asher, 1872): 21; Abraham Berger, "The Messianic Self-Consciousness of Abraham Abulafia-A Tentative Evaluation," in Essays on Jewish Life and Thought Presented in Honor of Salo Wittmayer Baron, eds. Joseph Leon Blau and Salo Wittmayer Baron (New York: Columbia University Press, 1959): 5960, note 19; Idel, Studies in Ecstatic Kabbalah, 48-50; Idel, Language, Torah, and Hermeneutics, 75; Idel, Ben, 370-71, note 213; Hames, Like Angels on Jacob’s Ladder, 66-69; Wolfson, Venturing Beyond, 60-61, 64-67; Elliot R. Wolfson, “Abraham ben Samuel Abulafia and the Prophetic Kabbalah,” in Jewish Mysticism and Kabbalah: New Insights and Scholarship, ed. Frederik E. Greenspan (New York: New York University Press, 2011), 72; Wolfson, “Textual Flesh, Incarnation, and the Imaginal Body,” 204-5; Sagerman, The Serpent Kills, 58, note 98; Kaufmann Kohler, Jewish Theology Systematically and Historically Considered (New York: Macmillan, 1918), 434; Avishai Margalit, “The Ring: On Religious Pluralism,” in Toleration: An Elusive Virtue, ed. David Heyd (Princeton: Princeton University Press, 1996): 148. See also Appendix B note 98 below.

12 On the book and its influence, see Idel, “Abraham Abulafia's Works and Doctrine," 35-36, and Idel, Studies in Ecstatic Kabbalah, 63-71. On this period of febrile literary and propagandistic activities, see Appendix D.

13 Idel, "Sefer Yetzirah and Its Commentaries," 480-94. 
in the chapter where it appears and more concerned with the similarities and differences between his version and Boccaccio's “original” story in the Decameron. In any case, the framework has not been analysed in detail, and therefore nor has the message that Abulafia wanted to convey. This resort to a parable that is not found in Jewish sources is relatively rare in Abulafia's many writings. Unlike the Hebrew and Greek Bibles, the Talmudic literature, and even Maimonides's Guide of the Perplexed, ${ }^{14}$ Abulafia was less concerned with this type of literary device, the resort to the pre-existing parable of the pearl being an exception. Moreover, he explicitly points out in the context of the parable that he is addressing an esoteric dimension of matters, a vital issue which has not been put into relief in the scholarly interpretations of this parable with which I am acquainted.

Therefore, let me translate the salient context of the parable as well as the parable itself and then discuss them in some detail. In this way, I will make sense of this special version of the parable, as Abulafia intended. In my opinion, it is only when the full context is seen that a better understanding is possible. Given Abulafia's esoteric approach, quotations of short segments can lead to an entirely different picture of his meaning. As such, an analysis of the larger text and not merely of a few segments taken from different books is a much-needed type of engagement with Abulafia's thought. In this way, the specificities of his discourse and its esoteric valences, only rarely addressed in the thematic approach, can be made clear. Paying greater attention to longer segments of discussion compels an engagement with wider contexts that are otherwise ignored in scholarship. While the thematic approach is determined by the assumption that a particular thinker's method had a significant coherent structure, the textual one sees understanding the text as the scholar's most important task.

The parable is part of a rather short chapter that is, according to its title, intended to demonstrate the superiority of the Hebrew language. ${ }^{15}$ Given the fact that following Aristotle's De Interpretatione 16a, the basic function of transmitting the mental message in any language works through the use of different sounds, Abulafia claims that we may discern which is the best language by checking the specific nature of the nation that uses a certain language. He writes:

[a][1] It is known that a nation that possesses Torah and commandments, laws, and regulations that are more righteous than another [nation] is more respected by that which emanates on all. ${ }^{16}$ And as much as the nation has moved away from the universal religion [ha-dat ha-kelalit $]^{17}$ that

14 On Maimonides's theory of parable and its background, see Stern, The Matter and Form of Maimonides's Guide, 18-63.

15 The Hebrew text of the entire chapter is printed, with reference to several manuscripts, in Appendix A.

16 Perhaps God or the cosmic Agent Intellect.

17 According to one of the manuscripts I consulted (see Appendix A, note 1205), the Hebrew is $h a$ da'at ha-kelalit, which means "the universal knowledge." However, this phrase is not repeated in other discussions in Abulafia's extant writings. Given the specific context of the occurrence of the 
was hinted at, it is more remote from that which is the first cause of the influence of the religion, which is the divine overflow ${ }^{18}$ that moves the universal speech [ha-dibbur ha-kelali]. ${ }^{19}$ [2] It is known among the nations that our nation is the nation that first received the Torah from the mouth of the Dynamis, and there is no nation that denies this. And what is acknowledged by everyone and has become known in public does not need further proof. If so, that which originates from the source of all is superior to its counterparts, and its language is superior to all other languages. And the witness is that it is in the language of this special nation that $\mathrm{He}$ spoke all that He spoke, ${ }^{20}$ and in its writing [namely, the alphabet] that He commanded all that he would write to be written. Furthermore, what He said was written by Him on the two tablets of stone, either if this is according to the plain sense alone or if it should be understood in both the exoteric and the esoteric senses. And either both senses are true, or one of them is; indeed, it was written in the Holy Language and the tradition persists to this day. [3] If one will say: "It was true, but behold, the nation is not worthy of this exalted degree and He changed it for another nation, and He changed its laws and commandments, and He came and diminished them and changed their writing," indeed, by necessity, he who says this, he himself confesses its degree, and the degree of its language and the degree of its writing. After he concedes the principal matter, the quandary occurs since the above-mentioned three degrees are today absent from it [or us]. And if we do not question him on the sensible deficiency, since we would be denying the obvious, we could not ascertain the intellectual since the sensible precedes the intellectual by nature, despite the fact that the intellectual precedes the sensible in degree [...]. But

phrase, the variant "universal religion," which is found in more manuscripts, is more cogent. The phrase dat kolelet, which is a close parallel to Abulafia's phrase, is found in a much later fourteenth-century sermon. See Ari Ackerman, "Zerahia Halevi Saladin and Joseph Albo on Natural, Conventional and Divine Law," Jewish Studies Quarterly 20 (2013): 333. It is translated on 336 as "comprehensive law." For natural law in Judaism, see Avi Sagi, Existentialism, Pluralism, and Identity, eds. Hava Tirosh-Rothschild and Aaron Hughes (Leiden: Brill, 2015), 59-102. On the meanings of dat in the context of a more general type of religion, see Menachem Kellner, "Maimonides' 'True Religion': For Jews or All Humanity," Meorot 7, no. 1 (2008): 2-28. For a recent survey of the meaning of and developments related to the term dat, see Abraham Melamed, Dat: From Law to Religion: A History of a Formative Term [Hebrew] (Tel Aviv: Hakibbutz Hameuchad, 2014), 55-59.

18 Some lines before this, Abulafia speaks about the universal overflow or influx ( $h a$-šefa' $h a-k e l a l i$ ) that moves the universal speech (ha-dibbur ha-kelali). See Or ha-Śekhel, 32, 33. Compare also to what Abulafia wrote in "We-Zot li-Yehudah," 27: "The Torah, as well as all speeches, are as a hyle for thought [maḩašavah]." Here, thought is human thought. It should be pointed out that Abulafia considered the oblivion of language to be a regress into a state of animality, and he also includes Jews in this category. See the two texts analysed in my Kabbalah in Italy, 84-85. For the relationship between the Agent Intellect and the seventy languages, see Mafteah ha-Hokhmot, 60. Compare, however, to the quite different interpretation of Wolfson, "Deceitful Truth and Truthful Deceit," $114^{\star}-15^{\star}$, who translates the Hebrew term dibbur as "language" instead of "speech," and grounds his analysis on this mistranslation of language as a historical and thus a particular phenomenon, ignoring Abulafia's phrase "universal speech" found in this very passage. See also his other translation "universal word" below in chapter 14 note 51 .

19 Paragraph [a1] has not been translated in the various accounts of the parable and is only rarely mentioned in passing; there has never been a proper analysis of its contribution to understanding the parable.

20 The assumption that God spoke is quite problematic in Abulafia's worldview; Abulafia assumes that God is an intellect, as Maimonides did. See his Guide 2:48, and Stern, "Maimonides on Language and the Science of Language." 
we shall acknowledge the truth that nowadays the three degrees are absent from us, though not by way of the exchange of one for another.

[b] Rather, the matter resembles a $\operatorname{man}^{21}$ who had a beautiful pearl which he wanted to bequeath to his son. While he was instructing his son in matters of wealth so that the son would recognise the virtue of the pearl and would value it in the same way as it was valued in the eyes of the father, the son came and angered the father. What did the father do? He did not want to give the pearl to another person, lest the son lose his inheritance if he wanted to repent and to please his father, but he cast the pearl into a pit and said: "If my son does not repent, I do not want him to inherit it, but if he repents, I do not want that he should lose it. And as long as he does not repent, it will be stored in the pit, and when he repents, I shall immediately take it out of the pit and give it to him." As long as he did not repent, the father's servants ${ }^{22}$ came each and every day and aggrieved him, and each of them would boast that his master had given him the pearl. But the son did not pay attention to them, because he had no intelligence [hasar da'at]. After a while, they so aggrieved him that he repented, and the father forgave him and brought the pearl out of the pit and gave it to him. The servants had to exert themselves for griefs they had caused him and offered many words of appeasement.

[c] This has happened to us in the case of those who say that God has taken them in exchange for us, for all the time that we do not make peace with God, because we have sinned, we have no mouth to answer them. However, when we repent, and He returns our captivity, those who shame us now will be ashamed when they see that God has returned our captivity; they will see that their thought and imagination [were wrong] and that we have been afflicted for our sins, but that we have all been absolved. As of today, we have not attained that exalted degree to which we expect to rise at any time. For this reason, the dispute continues about who is the beloved of God and who has the treasure and the truth, us or our enemies. This will persist until the decider [ha-makhri $a]^{23}$ comes and takes the pearl out of the pit and gives it to His chosen, to us or to them. Then the absolute truth will become perfectly clear and the precious treasure will become radiant and return to its rightful owners, those worthy to inherit it, those who are called the sons of God. [Then] jealousy and strife [and] disputation and hatred will cease, and imaginative thoughts will be obliterated from their hearts. Then, each and every man will consider each and every member of the species as if he is his fellow and his fellow is himself, just as a man can see every one of his limbs as if it is another's/another person's and each part of them is everything for him, "and many will go about and knowledge will increase." 24 No one

21 I do not know why Wolfson, both in Venturing Beyond, 60, and in "Textual Flesh, Incarnation, and the Imaginal Body," 204, claims that Abulafia's parable speaks about a king or about the son being a prince. Nothing in the printed Hebrew text or its manuscripts with which I am acquainted points in this direction. See the Hebrew original in Appendix A.

22 The Hebrew is 'eved, which can also be translated as "slave."

23 Or arbiter; this is most likely a reference to the prophet Elijah, who, coming before the Messiah as a harbinger, was often understood in Jewish sources as deciding issues that cannot be resolved by the ordinary kind of human decision-making. See Idel, Studies in Ecstatic Kabbalah, 57, note 22. Since Elijah as a human person and a harbinger of the Messiah does not play a role in Abulafia's eschatology, I assume that the decider here is the cosmic Agent Intellect that was associated with this intellect in Sitrei Torah. See Idel, Ben, 279-82 and 289. Indeed, Abulafia relates makhri'a to Metatron in Or haŚekhel, 82. On the other hand, the word makhri'a stands for the intellect that is found within man in a passage in Or ha-Śekhel, 41. Interestingly enough, the Hebrew form of Elijah, Eliyahu, contains the consonants ' $H W Y$ plus the letter lamed.

24 Daniel 12:4. 
will instruct his fellow man and say "Know God!" for all shall know the name, ${ }^{25}$ from the greatest to the smallest, "for the earth will be filled with the knowledge of God, as the water that covers the sea." ${ }^{26}$ Since the matter is so, all have agreed from that time that the chosen language is the Holy Language. Therefore, I will make known that which was made known to the prophets concerning the secret of the pronounced name, which is not known to any of the members of the human species. ${ }^{27}$

\section{Three Different Narratives in Abulafia's Writings}

In my opinion, the above passage is a good case for testing the need to interpret Abulafia in the context of his being a follower of Maimonides. The passage from Oșar 'Eden Ganuz discussed in chapter 10 above, in my opinion, provides the clue for understanding the parable translated from Or ha-Śekhel, as well as its context: Maimonidean thought, especially his allegorisations, coupled with similar Neo-Aristotelian views, should be understood as quintessential for understanding Abulafia's hints related to the parable.

I would like to distinguish between the three different types of narrative that are found in the above passage: the parabolic one, found in paragraph [b], which consists of a resort to the genre of parable; the historical one, found in both [a] and [c], which I shall call the second narrative and which is a horizontal interpretation of the parable that deals with national redemption; and finally, a third one that is only hinted at when Abulafia refers to it in [a2]. Such a distinction between these three levels is certainly Maimonidean. ${ }^{28}$

This third narrative, essentially a different conceptual register from the second, national one, deals with the esoteric meaning of some concepts Abulafia uses that are also implied in other instances. This narrative is a psychological allegory that is transhistorical and vertical; it deals with personal redemption, which is attainable

25 Or God. The assumption is that the knowledge of God depends not on human instruction, but on direct contact with divinity, an assumption that fits Abulafia's claims of revelation from above. Compare to Zohar 3, fol. 130b: "In the days of King Messiah they will not have to teach one to one." 26 Isaiah 11:9. I have no idea why Hames (Like Angels on Jacob's Ladder, 135-36, note 28) deemed the "similarities" between this part of Abulafia's passage and a text of Joachim of Fiore to "stand out." I see neither similarities nor parallels between the two texts; indeed, there are no parallels even between the biblical verses that these texts used as proof-texts.

27 Ms. Vatican, 233, fols. 37b-39b, printed from different manuscripts by Gross, 33-36; Matityahu Safrin (Jerusalem: 1999), 41-44; and Ohr ha-Sechel: The Light of the Intellect, eds. and trans. Avi Solomon, Adam Shohom, and Sharron Shatil (s.l.: Providence University, 2008), 47-50, 202-4. The Hebrew original of this passage is printed in Appendix A below. I have also printed and translated the discussion that follows the translated passage here, designated as paragraph [d]. Some details of paragraph [d] will be discussed in various footnotes in chapter 24 and Appendix A below.

28 See Stern, The Matter and Form of Maimonides’s Guide, 61-63, and see also 66-73. 
by a union with a "higher" intellectual entity. ${ }^{29}$ From some points of view, it is parallel to the manner in which Christian authors understood the anagogical interpretation. Needless to say, this third level is the most important one for Abulafia, who, following the lead of two books written by Maimonides and Al-Fārābī that he knew and quoted, as well as that of Averroes, subscribed to a political type of esotericism. The allegorical type of discourse as practised by Maimonides-and, following him, Abulafia-is by nature atemporal, as I showed above in chapter 9 in my discussions on the Paradisiacal and Sinaitic experiences. In my opinion, this insistence on the spiritual register contains one of Abulafia's most important contributions to Jewish mysticism, esoteric as it sometimes is.

However, given the concentration on the parable's historical dimensions and background displayed by some scholars who were more concerned with the parallels of the parable and its reverberations, as well as the assumption that the ultimate significance of the passage is the historical fate of the Jewish people or mankind as a whole (i.e., the second narrative), little has been done to put into relief the existence and significance of the third level of narrative (i.e., the esoteric one). This latter register has been neglected in most scholarly analyses of the parable and of Abulafia's type of mysticism in general. In the following discussion, I will broaden some observations I have already made about it in the past. It should also be pointed out that there is no reason to assume that it is possible to coordinate the details of the parable to every detail of the two narratives, a well-known problem in interpretations of parables in general, still more so when a parable is adopted from earlier sources.

The assumption that there are three different narratives is not explicitly formulated either in the parable itself or in its immediate context. Rather, this assumption is the result of my analysis of the material found in Or ha-Śekhel and elsewhere in Abulafia's writings, though its pertinence may be contested. However, this assumption is corroborated by a rather instructive statement found in the context of the interpretation of a lengthy vision Abulafia reports experiencing in his prophetic composition Sefer ha-Ot. After formulating the details of his vision of the wars between four warriors and the arrival of a fifth figure, he asks for an interpretation of these visions from the supernal figure who was revealed in his vision; namely, the angel Yaho'el. ${ }^{30} \mathrm{He}$ then says that the four warriors refer to four kings who will come at

29 On the two registers, see Idel, Messianic Mystics, 84, 90-91, 283; Idel, "The Time of the End"; and Idel, Kabbalah in Italy, 74, 82. For Abulafia's view of atemporal intellectual experiences, see already Moshe Idel, “'Higher Than Time': Observations of Some Concepts of Time in Kabbalah and Hasidism," in Time and Eternity in Jewish Mysticism, ed. Brian Ogren (Leiden: Brill, 2015): 179-210, a part of which has been reproduced in Appendix E below.

30 On this angel and Abulafia's possible source for this rather rare name, see Idel, Ben, 18, 120, 206, and 209-11; Messianic Mystics, 85-94; and Moshe Idel, The Angelic World: Apotheosis and Theophany [Hebrew] (Tel-Aviv: Yedioth Ahronoth, 2008), 135-48. Abulafia's discussion of Yaho'el in his Sitrei Torah, perhaps for the first time in his writings, was one of his first pieces to find its way into print in Italy. See Liqquței Šikhehah u-Fe'ah (Ferrara: s.n., 1556), fols. 232b-24a. See also Appendix D note 212 below. 
the end of time; the fifth is to be identified as the Messiah. ${ }^{31}$ Abulafia continues: "This is an interpretation that is evident to everyone, but the hidden interpretation will be understood [only] by someone who understands from his own knowledge."32

The term translated as "interpretation" is pitron, which also means "a solution to an enigma." It occurs in many instances in Jewish sources, including Abulafia, ${ }^{33}$ in exegetical contexts to refer to the possibility of decoding the meaning of a dream. This fact brings the vision closer to the common usage of decoding, meaning that the prophetic vision found in a text composed by Abulafia himself can be understood according to two different interpretations: the first deals with the arrival of the Messiah after the eschatological wars, while the second is conceived as being hidden or spiritual and most likely deals with an individual's inner redemption. ${ }^{34}$

The concept of something being "hidden" is to be understood according to its two senses: unlike the first type of interpretation, it is hidden from the public; that is, it is a political type of esotericism. In addition, it also means a secret sense of a narrative-namely, some form of allegory-which does not necessarily have to be problematic from the political point of view. ${ }^{35}$ In other words, the eschatological secret undergoes an allegorical interpretation that removes the apocalyptic elements in the first type of interpretation (the second narrative).

The second register or narrative (namely, the national one) can be understood as myths that are necessary for the education of the masses; in our case, the creation of a shared hope of a better future for the national unit that is political but, at the same time, devoid of any inner spiritual or atemporal meaning. In some cases, it can also

31 Sefer ha-Ot, ed. Jellinek, 84.

32 Sefer ha-Ot, 85:

והנה הגבור חמישי הוא משיחי אשר ימלוך אחר מלחמת ימי ארבע מלכויות. זה פתרון הנגלה לכל, רק פתרון הנעלם יבינהו

המבין מדעתו.

33 See Mafteah ha-Hokhmot, 41 and 55, and especially Mafteah ha-Šemot, 29-30, where the pitron deals with more of an intellectual aspect that differs from the national interpretation found there. See also Moshe Idel, Nocturnal Kabbalists [Hebrew] (Jerusalem: Carmel, 2006), 15-36. Compare to Commentary on Iš Adam, 49, printed in Mașref ha-Śekhel: "And Raziel started to say that he concentrated [his mind] and told [future] events, and they are known in accordance with the plain sense and the esoteric one."

$$
\text { והחל עוד רזיאל להגיד שהתבודד והגיד הקורות והן ידועות בנגלה ובנסתר. }
$$

For the possibility of a hierarchy of readings of the narratives in the canonical texts of Maimonides, see Diamond, Maimonides and the Hermeneutics of Concealment, 19-20.

34 Compare to Mafteah ha-Hokhmot, 54, where the primacy of the kingdom of Israel (מלכות ישראל) מלכלית over the four kingdoms corresponds to the "powers of the soul," both referred to by two letters, א"ד. I assume that both Yiśra'el and Malkhut are terms that stand for the Agent Intellect, as well as for "general" or "universal." See Idel, "Definitions of Prophecy: Maimonides and Abulafia," 6, 913.

35 See also the Commentary on Sefer ha-'Edut, 76, where he refers to הנסתר האמתי; that is, the true hidden sense of his vision. See also Rabbi Isaac of Acre's view of the true hidden sense, as discussed in Boaz Huss, "Nisan, the Wife of the Infinite: The Mystical Hermeneutics of Rabbi Isaac of Acre," Kabbalah 5 (2000): 155-81. 
be understood as a canonised belief that can be interpreted as having an inner meaning that is infused with the internal experiences of members of the elite. In other words, the utopian narrative of the second register concerning the fate of the nations can be understood as secretly referring to something higher; namely, to a perfect spiritual state that an individual may attain in the present. To put it in another way, the two narratives that were used in order to interpret the first narrative of the parable can also be seen as the external-the second narrative-versus the internal sequence of events; namely, the third narrative or register. In my opinion, another important example of the three types of narratives can be found in a brief discussion of a prodigal son or student who does not want to learn the truth, as in the pearl parable, which is interpreted both as the people of Israel and as an individual standing before God..$^{36}$ In fact, these two interpretations coexist in the same text, though they convey different eschatological meanings, a phenomenon I propose to describe as synchrony. ${ }^{37}$

In more general terms, it should be mentioned that Abulafia makes recourse to the concept of polysemy. So, for example, he wrote commentaries on some lost and quite enigmatic books, in which he committed his own revelations to writing, and in one of these, we find instances of terms used in the prophetic books which had more than one meaning. One such example, which will be translated in chapter 20 below, is when the term "Messiah" is interpreted as having three different meanings, two of them explicitly related to Neo-Aristotelian philosophy. ${ }^{38}$

It should be mentioned that there are good reasons to assume that the hidden or secret interpretations may refer to Abulafia's own role as a Messiah or to the special significance of specific episodes in his life-for example, the meanings of the names of the cities where he lived. ${ }^{39}$ It is in these secret interpretations, not the national narrative that he considers to be known to everyone, that Abulafia believes the most important messages can be found. In my opinion, this is also the case in the parable of the pearl. Especially important is the fact that Abulafia explicitly asserts that the two interpretive narratives may contradict each other. In other words, based on my assumption that there is an esoteric narrative that constitutes the highest form of knowledge that Abulafia would like to communicate, we should differentiate between the more particularist (exoteric) expressions in his books and the more univer-

36 Hayyei ha-'Olam ha-Ba', 196-97.

37 See Idel, “Abraham Abulafia: A Kabbalist 'Son of God."” For the coexistence of different narratives in the same text and the application of exegetical methods characteristic of the interpretation of sacred scriptures to one's own writing, see my "On Symbolic Self-Interpretations in Thirteenth-Century Jewish Writings," Hebrew University Studies in Literature and the Arts 16 (1988): 90-96; on Dante, see Robert Hollander, "Dante Theologus-Poeta," Dante Studies 94 (1976): 91-136. This has nothing to do with Jung's well-known concept of synchronicity.

38 See chapter 20 below as well as Rabbi Moses ibn Tibbon, The Writings of Rabbi Moses ibn Tibbon: Sefer Pe'ah, 99.

39 See Idel, “On Symbolic Self-Interpretations in Thirteenth-Century Jewish Writings.” 
salist (esoteric) ones, which is an issue that has been obfuscated in the recent scholarship on this Kabbalist.

\section{A Commentary on the Parable's Contexts}

The starting point of paragraph [a1] makes the connection between the universal speech and the universal religion, which means that the best language (general speech) is related to the best religion (the universal one). In order to determine the best language, which is the main topic of the chapter, one has to review the structure of the nation associated with it. These two topics are therefore related to each other. A third topic, the script, is not mentioned in this specific context, though it is mentioned together with the other two later in the discussion.

The central theme of the long passage is a concept which, I believe, cannot be found in Jewish writings before Abulafia or even elsewhere in his writings: the universal religion (ha-dat ha-kelalit). This religion is described as part of the past, a conclusion based on the use of the past tense of the verb "to move away," and constitutes a form of ideal criterion against which every other religion is judged. Though the phrase does not occur anywhere else in Abulafia's writings, we may be able to guess its meaning from the surrounding context in paragraph [a], as well as the content of paragraph [c]. In paragraph [a], this concept is parallel to the universal speech since both the universal religion and the universal speech emanate from the divine influx. ${ }^{40}$ The term "universal speech" parallels natural speech (the twenty-two letters), as we learn from his discussion. ${ }^{41}$ We may assume that the divine influx is

40 What exactly Abulafia meant by Dat is not so clear. For example, see his enumeration of the ascending categories in Ms. Firenze, Laurenziana, Plut. II, 48 fol. 94b:

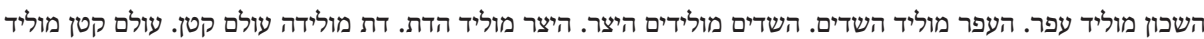

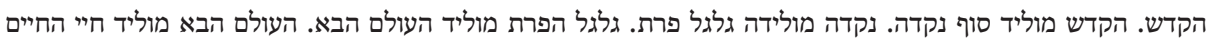

החיים תמיד.

The view that demons generate religion should be understood as the involvement of imagination in the formulation of religion. I assume that the world to come is some form of intellectual entity, human or cosmic, and that this world generates a higher form of life, perhaps the divine life. It is plausible that from the semantic point of view, he is following the lead of Maimonides's Mishneh Torah. See Hilekhot Yesodei ha-Torah 71:1, 9:2, and Hilekhot Melakhim 10:9. According to Warren Zev Harvey, Maimonides refers several times to dat ha-emet as some form of universal religion in his Mishneh Torah. See Hilekhot Melakhim 4:10, 12:10. See also Kellner, They Too Are Called Human, 55-56; and Hava Tirosh-Samuelson and Aaron W. Hughes, eds., Menachem Kellner: Jewish Universalism (Leiden: Brill, 2015). For more on the term dat in the Jewish Middle Ages, see Melamed, Dat: From Law to Religion.

41 I do not know why Wolfson ("Textual Flesh, Incarnation, and the Imaginal Body," 204) translates it as "universal word." See also Sefer ha-Melammed, 24:

אך הצורה הכוללת כל כתב היא צורת הדבור הטבעית הדבקה בפה שהיא חקוקה בלב בעת היצירה. והעד שאילמלא לא היתה זאת צורת האדם לא היה האדם מדבר, ולא היה עיקר מציאות הדתו הפורת שדבור. 
an intellectual influx that is transformed in both speech and religion; it also includes imagination as part of the phenomenon of revelation.

In a very important passage in Hayyei ha-Nefeš, Abulafia discusses the past existence of one unified nation (ha-ummah ha-enošit) which had one religion (dat ahat) and one language (śafah ahat) which disintegrated with the attempt to build the Tower of Babel. ${ }^{42}$ Interestingly enough, in this context, he does not mention the common type of writing. How the universal religion emerged is not clear. Therefore, I propose to identify the phrase dat kelalit in Or ha-Śekhel with the ancient single religion mentioned in Hayyei ha-Nefeš. This identification seems to be plausible because of a distinction in the latter book that refers to the earlier discussion of one single religion. There, Abulafia speaks about the universal Torah and the particular Torah, Torah kelalit and Torah peratit. ${ }^{43}$ Thus, it seems that the Torah that was revealed to the Jews-namely, the written Torah-is a particular Torah that came later than the unwritten and universal Torah.

It should be noted that according to two of Abulafia's texts, the Torah was known orally before Moses committed it to writing, which is quite a radical approach, especially for someone in the Maimonidean camp. ${ }^{44}$ According to one of these passages,

\begin{abstract}
"The universal form that comprises the entire script is the form of natural speech that sticks to the mouth, which is engraved in the heart at the beginning of creation [of man]. And the testimony is that this would not be the form of man, man would not speak and the essence of his existence would not be speech." Sefer ha-Melammed, written, at least in part, in 1276, is perhaps the first Kabbalistic book written in the Byzantine Empire. Compare to chapter 13 note 29 above. On natural language in Abulafia, see the text preserved in a seventeenth-century manuscript translated in Idel, Language, Torah, and Hermeneutics, 14, as well as 16-27. See also Allison Coudert, "Some Theories of a Natural Language from the Renaissance to the Seventeenth Century," in Magia Naturalis und die Entstehung der modernen Naturwissenschaften, ed. Albert Heine (Wiesbaden: Steiner, 1978): 56-118.

42 Hayyei ha-Nefeš, 80. The background of some of the terms is evidently the verses in Genesis 11:1-9. On the similarity between other passages of Abulafia's discussion of the confusion of languages and their dispersion as well as Dante's view, see Dante Alighieri, De l'éloquence en vulgaire, trans. Irène Rosier-Catach (Paris: Fayard, 2011), 44-45, 115. See also chapter 4 note 49 above.
\end{abstract}

43 Hayyei ha-Nefeš, 151.

44 Oṣar 'Eden Ganuz, 1:9, 178-79:

ואמנם בדעתנו שיש שם אומות זו מזו משונות והם אינם בעלי דתות, ראוי לומר שהאומות קדמו לחלוק הדתות ולשנוייהם.

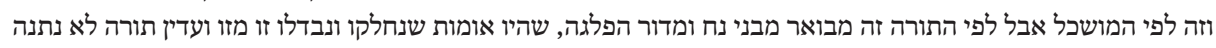
מפורסמת עד בא משה ומן התורה נתחדשו שאר הדתות. מבני נחורור.

See also Mafteah ha-Hokhmot, 91-92:

זאת התורה השלמה [...] ומצותיה באו בה להבדיל זו האומה בחקים ומשפטים ידועים לה ונעלמים מכל האומות שהן

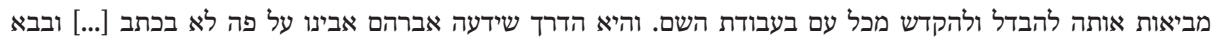

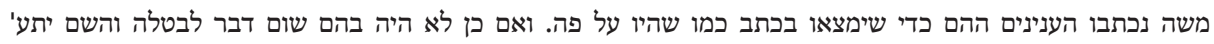
רצה שתתפרסם מעלת זאת האומה הקדושה לעיני כל העמים כמים שמים. "This perfect Torah [...] and its commandments came in order to distinguish this nation by means of laws and regulations known to her, but unknown to all the other nations, which separates her from any people by means of the worship of God. And this way was known to Abraham our forefather, orally, not in a written form [...], and when Moses came, those issues were written down, so that they will be found in a written form as they were in an oral manner. And there was, therefore, nothing 
it was only after the Torah had been written down that various religions were derived from it, though the laws (huqqim) had been there all the time. ${ }^{45}$ Thus, as Abulafia asserts, given that the written form was identical to its oral transmission, Moses became more of a scribe than a divinely inspired law-giver. ${ }^{46}$ This merely technical role attributed to Moses needs more clarification than can be given in this context. Indeed, Abulafia also describes Moses as "the leader," 47 which would shift the emphasis from Moses's role as a perfect and unique legislator, as the law already existed, to that of a great leader. ${ }^{48}$ In my opinion, this emphasis allows for an easier explanation of the possibility that Abulafia conceived himself to be higher than Moses because his revelation was the ultimate one.

In any case, we may ask who, in Abulafia's view, was the first (oral) recipient of the Torah if it was not Moses? May we understand that the pre-existing Torahwhich, in its oral form was an intellectual entity, universal religion, or universal Torah that could not in principle be committed to writing ${ }^{49}$-was turned, through its written transmission, into a combination of intellect and imagination? And if so, is this the reason why the other religions that appeared afterwards were a further deterioration of the original religion-the oral and intellectual one that he refers to as the universal religion, what he calls the ancient universal faith ${ }^{50}$ Such a historiosophical narrative would indeed put Abulafia at the very extreme of the radical Maimonideans and explain why he so often had to resort to an esoteric discourse.

The turning away from that universal religion is similar to what happened to the universal speech after the Tower of Babel. However, according to an important dis-

superfluous and the Holy One, blessed be He, wanted to publicise the rank of this holy nation, in the eyes of all the nations."

45 Oșar 'Eden Ganuz, 1:9, 178-79. See Hames, Like Angels on Jacob's Ladder, 57-58. Perhaps Abulafia was capitalising on, though strongly reinterpreting, the Rabbinic view that the forefathers kept all the commandments and studied the Torah. See Arthur Green, Devotion and Commandment: The Faith of Abraham in the Hasidic Imagination (Cincinnati: Hebrew Union College Press, 1989). I would not like to engage with the Rabbinic theme of the pre-existent Torah found on high before the creation of the world from which Moses copied as if he were a scribe because it does not fit the context of Abulafia's discussion. See Idel, Absorbing Perfections, 449-60, and the accompanying footnotes.

46 Mafteah ha-Hokhmot, 92. For Moses as a scribe, see Maimonides's introduction to Mishneh Torah, and in Kabbalah, see Idel, Absorbing Perfections, 458, and a series of additional sources. However, the assumption in those sources, unlike Abulafia, is that Moses copied as if from a supernal book, perhaps an example of Muslim influence. The oral pre-existence of the Torah as assumed by this Kabbalist is, therefore, quite a different attitude.

47 See Idel, "Definitions of Prophecy: Maimonides and Abulafia," 13-15.

48 See Menachem Lorberbaum, Politics and the Limits of Law: Secularizing the Political in Medieval Jewish Thought (Palo Alto: Stanford University Press, 2001), 72-75. On the other hand, see the view of Maimonides's Moses as a legislator advocated in Goodman, The Secrets of The Guide to the Perplexed, 352-53, note 11, as well as in the scholars mentioned in his note.

49 On this issue, see Idel, Language, Torah, and Hermeneutics, 48-49.

50 Sitrei Torah, 92. 
cussion in Or ha-Śekhel, the mythical episode that occurred at Babel has no meaning whatsoever for the illuminated person, but only for the multitude. ${ }^{51}$ This means, implicitly, that there was no specific historical moment for the dispersion of the nations or changes of languages; rather, these were natural processes that are similar to what we have seen above concerning the departure from Egypt or the reception of the Torah at Sinai. In this way, the dispersion of languages could even take place today, since the shift from the natural language with which one is endowed to a conventional language is a natural, innate phenomenon. While the spoken languages are artificial and conventional entities the infant must learn, and thus particularist, the ideal sounds are innate and thus universal.

I consider the emphasis on universality to be related to intellectuality and the natural interpretation of religious documents. Some pages before the translated passage, Abulafia describes the transformation of the natural sounds into conventional speech or languages:

It is necessary from this ${ }^{52}$ that everything has a governor that does not move but governs everything from outside, which means that it is separated from them by its essence and it emanates providence upon them, and this is the human intellect that governs all the languages. But it is not moving, neither in essence nor accidentally, but the human intellect operates in the human species in actu from its side and in potentia from their side. And it is this ${ }^{53}$ that changed the languages after they had [once] been one entity, understood by all speakers, which today is also one entity, but it is not understood by every speaker, and this is because of the dispersion of the nations. $^{54}$

This view of the human intellect as being both separated from matter on the one hand and that which unifies the entire human species on the other represents, in my opinion, the impact of Averroes's later theory of a potential intellect that is common to all of humanity. ${ }^{55}$ As in Maimonides (Guide 1:74), his followers, and Averroes (at least in a later phase of his thought), for Abulafia, the human intellect is not just a personal quality, but a common entity shared by all humans. He envisions this human intellect as a mover of speech which is referenced in the quote by the term "one entity," causing the emergence of the seventy languages, just as the unmoved mover (God or the first separate intellect) moves the cosmic spheres, which govern

51 Ed. Gross, 39-40.

52 Namely, the manner in which the elements of language are moved so that speech emerges.

53 The human intellect.

54 Or ha-Śekhel, 31:

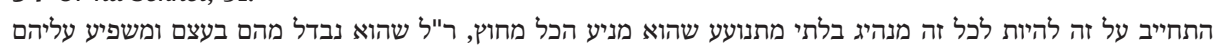

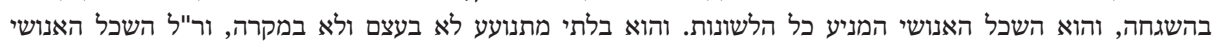

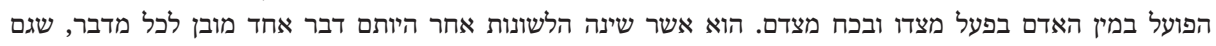

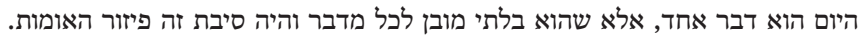

55 Maurice Blaustein, "Averroes on the Imagination and the Intellect” (PhD diss., Harvard University, 1984), 200-210. 
what happens in the terrestrial world. ${ }^{56}$ Those are, according to Abulafia, three distinct phases.

As we shall see in Appendix A, Abulafia conceives the emergence of languages as being related to letter permutations, which he describes as the movements of two concentric wheels that allow the extraction of all possible combinations of two letters from the twenty-two Hebrew consonants. Thus, language is perceived as emerging in a natural manner, semantically speaking. Its turns are diversified because of two main causes: the emergence of the allophones (which differ slightly from the twenty-two natural consonants) and ideal sounds (which linguists would call phonemic, given varying climatological factors), ${ }^{57}$ and secondly, because of the different combinations of letters that produce the conventional languages ${ }^{58}$ and which generate diversity, misunderstanding, and dispersion among nations. In a way, the transition between the natural language-understood by Abulafia as a sonorous simple speech-or Ursprache that is nevertheless still present and the conventional languages that transmit information that is contaminated by imagination is prefigurative of Noam Chomsky's linguistic theory of the innate potential of learning language and the possibility of speaking many languages.

The opening remarks about $a$ Torah and legal regulations can be understood either as being identical to the universal religion or as being different from it; each reading constitutes quite a different understanding of the text. The former can be described as a more universalistic vision of "the Torah" and the latter as a more particularist "a Torah." I believe that the second interpretation is the more plausible one, if we allow the rather bizarre formulation of "a Torah." Let me point out that the need to take the absence of the definitive form into consideration is not an exaggerated interpretation, but follows Abulafia's clear statement in which he assumes that there are single letters that hint at an esoteric sense on the one hand ${ }^{59}$ and the distinction between the universal and the particular Torah, mentioned above, on the other. The accuracy of the law constitutes the closeness or distance from the divine

56 On the different positions among Muslim philosophers on this issue, see Harry A. Wolfson, "Averroes's Lost Treatise on the Prime Mover," in Studies in the History of Philosophy and Religion, 1:402-29; Harvey, "The Mishneh Torah as a Key to the Secrets of the Guide," 17-19; Joseph Puig, "Maimonides and Averroes on the First Mover," in Maimonides and Philosophy, 213-23; and Even-Hen, "Maimonides's Theory of Positive Attributes," 19-45.

57 See Idel, Language, Torah, and Hermeneutics, 3-4.

58 Idel, 8-11. I will reproduce here the astute note by Warren Zev Harvey: “In his Hebrew: The Eternal Language (1957), 'Hebrew-the Mother of Languages,' 18-19, William Chomsky recalls romantically the old view, held by Jews and Christians until the eighteenth century, that 'all the languages of mankind [...] derived from Hebrew,' etc. Cf. Noam Chomsky, 'Morphophonemics of Modern Hebrew' (1951). I think that the most likely explanation for the mystical and unempirical nature of Chomsky's theory of 'universal language' is that it is a modern version of the ancient view about Hebrew." William is Noam Chomsky's father.

59 Idel, Language, Torah, and Hermeneutics, 114-17. 
source that promulgated the universal religion/Torah, and I shall try to reinforce this reading later in this study.

The three degrees or values mentioned in paragraph [a] are Torah, the Hebrew language, and the Hebrew script (that is, the visual shapes of the Hebrew letters). Needless to say, these virtues are related to each other, as was explicitly mentioned earlier in this chapter, as they deal with a form of linguistic articulation. They are often described in opposition to the languages and religions of the Gentiles and as the opposition between intellect and imagination. ${ }^{60}$ It seems, however, that only the script or phonetics is explicitly described in the last sentence as being continuously in the nation's possession, while all three may actually be lost, as we may infer from the closing sentence of paragraph [a2]. I see no way to resolve this contradiction except through the assumption that there is an esoteric teaching that assumes that even the original Hebrew language has been forgotten, as Abulafia expressly mentions elsewhere in the same book. ${ }^{61}$

In any case, in a rather clear statement, Abulafia lists Hebrew writing along with and as one of the seventy other writings without distinguishing between them in this case. $^{62}$ In general, the basic assumption of the consonance between the superior society formed by a certain religion and the language that is spoken by it is logically difficult from the historical point of view: if someone tried to use this nexus in order to prove the superiority of Hebrew, they would run up against the difficult conditions of the exile, as Abulafia openly recognises. Moreover, the manner in which it is formulated in the context of the parable in paragraph [2], "that it is known" and agreed that the Jews antecede the other nations, is through the verb hitparsem, which is related to the noun mefursamot (the things that are known and widely accepted) and which is a low form of cognition in both Maimonidean nomenclature and, in some cases, in Abulafia's writings, where it is explicitly related to imagination. ${ }^{63}$

The Kabbalist also resorts to an existing dictum whose history in medieval Jewish thought is a desideratum. His approach regards intelligibilia as being higher than sensibilia, and the latter as being higher than things accepted only by dint of wide

60 See Idel, 19; the quote from "Ševa' Netivot ha-Torah," 14, discussed above; and Wolfson, Abraham Abulafia, 58-59. On the three virtues, see Oșar 'Eden Ganuz, 1:3, 183, 188.

61 See Idel, Language, Torah, and Hermeneutics, 13 and 23-24; see also Hames, Like Angels on Jacob's Ladder, 135, note 25. In Or ha-Śekhel, on the other hand, Abulafia states that the universal language is known even today, but is incomprehensible to its present speakers. See Idel, Language, Torah, and Hermeneutics, 20. In my opinion, Abulafia issued contradictory views as part of his political esotericism, which is a major methodological problem for understanding his hidden secrets that has not drawn sufficient attention in scholarship on this topic. See his Or ha-Śekhel, 70-71, 107, and Oșar 'Eden Ganuz, 1:3, 121, 122-23.

62 Sefer ha-Melammed, 24:

שארז"ל שבעים כתבים יש להקב"ה בעולמו [...] וכתב עברית היא אחת מהכתיבות. On Maimonides on the Hebrew language as a regular language, see Kellner, Maimonides's Confrontation with Mysticism, 155-78, and Stern, "Maimonides on Language and the Science of Language." 63 See Ḥayyei ha-Nefeš, 9 , 
agreement. In general, it may be assumed that the three gifts represent a lower modification of the intellectual mode that constitutes a particular historical religion, while the intellectual level is understood as the hidden layer.

Let me emphasise that the necessity of assuming an esoteric register is not my own subjective imposition: it is explicitly stated by Abulafia himself in paragraph [a2]. In a manner reminiscent of the parable's son who will not receive instruction, we read in his commentary on the secrets of Maimonides's Guide of the Perplexed about the Jews "turning away from an earlier tradition they possessed, which is mentioned in the following quote: "And all this [the account of the chariot] you will know from the letters. ${ }^{64}$ No other nation has a tradition like this, and even our own nation is far from it, having quickly moved away from the path. This is the reason why our exile has been prolonged." ${ }^{65}$ Here, the state of exile is explicitly related to the obliteration of or a deviation from a tradition related to letters-namely, the written onereiterating the nexus between society and language mentioned earlier.

This turning away from a type of lore that is conceived as essential and yet unknown in the present is reminiscent of the straying away in the passage from Or ha- $\hat{S}$ ekhel translated above; ${ }^{66}$ in both cases, the exact same Hebrew verb is used: nitrahaqah ("moved away"). This may be interpreted not only on the second or national level, but also on the personal or third level, which means that by returning to the correct understanding of the function of language, a person may still escape from exile even today, though it will be on an individual basis. In his Sitrei Torah, Abulafia expresses the same idea that in the present (i.e., during the centuries of exile), the Jewish nation is oblivious to a specific type of wisdom which is key to the possibility of prophecy and which he considered to be the seventh and highest level of interpretation conducive to prophecy. ${ }^{67}$

The context of the parable has a very significant-and hitherto unnoticed-parallel that occurs in a lengthy discussion found in Abulafia's later book, Oșar 'Eden Ganuz, where the parable is not mentioned at all. ${ }^{68}$ The basic difference between

64 Compare to Sitrei Torah, 146:

והאותיות האלה הטבעיות והאלוהיות המצוירות בכל העולם.

65 Sitrei Torah, Ms. Paris, BN 774, fol. 162a, 158:

וזה כולו מתוך האותיות תבינהו, כי אין לאומה קבלה כזו, ואפילו אומתינו רחקה ממנה וסרו מהר מן הדרך על כן ארך גלותינו.

See also Idel, Language, Torah, and Hermeneutics, 25, 101-9, 184, note 205, and Wolfson, Abraham Abulafia, 61. This claim about the continuation of the exile because of the oblivion of an esoteric tradition contradicts his view, adduced in chapter 8 note 30 above, as well as its source, Maimonides's Guide.

66 See above, chapter 2 note 55.

67 Ed. Gross, 34-35. Let me emphasise that according to Abulafia, the lower methods of interpretation, and their corresponding human groups, are not superseded when someone advances to a higher one, since the multitude, Midrashists, and philosophers do not disappear when someone attains the highest, prophetic level.

68 Oșar 'Eden Ganuz, 1:10, 185-93. 
the two contexts can be seen in the more particularist formulations found in the later book in comparison to the more universalistic one found in Or ha-Sekhel. It should be mentioned that in the latter book, Abulafia does not refer to any biblical name in the historical narrative, though hints towards Moses and Elijah can be discerned. Nor does he explicitly refer to Christianity or Islam in this version. ${ }^{69} \mathrm{He}$ also chose not to mention any specific historical event, although the sin of the Golden Calf is perhaps at least hinted at, as has been correctly pointed out by Harvey Hames. ${ }^{70}$ This reluctance may be part of an attempt to de-emphasise the popular version of the eschatological narrative, which gravitates around personalities and external events; in short, the Kabbalist attempted to reduce the specificities of the second narrative.

\section{The Secret of Languages: "The Best of the Languages"}

The passage translated above is part of a chapter that intends to deal with "the best of the languages," which in the Hebrew original is ha-lašon ha-muvhar. In this context, Abulafia essentially addresses human language, since God, according to Maimonides as well as Abulafia, being an intellect, cannot speak. ${ }^{71}$ Let me translate the opening paragraph, which was not translated above (its Hebrew original can be found in Appendix A):

Behold, we have already announced general issues regarding languages, and we have explained that the divine influx moves all [the languages] and that it is the reason for their existence, from potentiality to actuality. ${ }^{72}$ And given that this is the case, it is necessary to announce whether they are all equal for Him or whether they are unequal, provided the fact that they are all His acts and because it is known that they are equal from His side, they are also equal for Him from the perspective of their existence, because their matter is the universal speech, and it is He that gives particular forms to it, and they are comprehensions that are intelligised from the speech, and given that the comprehension is equal, everything is equal, but the difference between the languages will be similar to the difference between the nations, and similar to the difference between nations is the difference between their scripts.

The equality between all languages from the perspective of the divine influx, and perhaps also that of God, is predicated on their all being divine acts and their all sharing the same prime matter (the universal speech material), which in Abulafia's thought consists of the twenty-two consonants of the Hebrew language. This

69 Compare, however, to Wolfson, "Textual Flesh, Incarnation, and the Imaginal Body," 204. It should be mentioned that in the parallel discussion in Oșar 'Eden Ganuz, 1:9, 183, the names of the three founders of the three monotheistic religions are explicitly mentioned.

70 Hames, Like the Angels on Jacob's Ladder, 69.

71 See Guide of the Perplexed, 1:65, Pines 1:158-60, and Stern, "Maimonides on Language and the Science of Language," 174-78.

72 Compare also to what Abulafia wrote some pages later in the same book, Or ha-Śekhel, 38-39, and to Oșar 'Eden Ganuz, 1:10, 192. 
means that the divine influx operates, in the manner we find in the Avicennian and Maimonidean concepts of the Agent Intellect, as the donator formarum (the giver of forms) to the ideal sounds of language that function as the hyle, the speech, as described in Sefer Yeșirah.

From these two points of view, there is no reason to make a substantial distinction between the various languages since their referents (what they convey or their "comprehension") are conceived as identical despite the disparity of the words used by the different languages. At the same time, the ideal vocal articulation is constituted by the same principle of combinations of the same natural sounds. This principle is also expressed in Abulafia's Untitled Treatise:

\begin{abstract}
I have already announced to you the secret of the languages, which is the seventy languages that are contained under the one Holy Language; namely, that it is one and unique and better than all the others. And how is this secret? I shall tell you if you have a heart to understand the essence of the matters that are necessary in our opinion, from the point of view of Kabbalah. Know [that] they instruct [how to employ] the combinations of letters, namely to turn them backwards $^{73}[. .$.$] and the secret is that all the seventy languages will emerge because of the combi-$ nation of letters, generation and decay, and its secret is very great. ${ }^{74}$
\end{abstract}

What is the great secret of a topic that is something which can be understood simply as dealing with the superiority of the Holy Language? What is the "secret of languages" or, according to a phrase that is found many times in Abulafia's writings as well as in Or ha-Śekhel, "the secret of language"? Let me first decode the gematrias: "one Holy Language" in Hebrew is Lešon Qodeš ehad = 798 = ha-Lešonot ("the languages"). More widespread is the other calculation, the seventy languages: šive im lešonot amounts to the combinations of letters șerufei otiyyot $=1214 .{ }^{75}$ In Hebrew, the term Galgal refers to both "sphere" and "wheel." The combinations of letters are made by means of rotating concentric wheels, and this motion is compared to the process

73 I have translated אחור as a mistake for אחור . wחר would mean "to turn one of the wheels used in order to generate the combinations of letters in the inverse direction."

74 Ms. Firenze, Laurenziana, Plut. II, 48, fol. 99b:

וכבר הודעתיך סוד הלשונות והוא שבעים לשון שהם נכללים תחת לשון הקדש אחד כלומר שהוא אחד מיוחד ונכבד מכלם

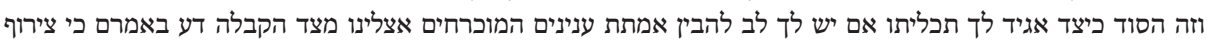

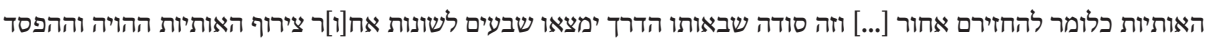

סודו גדול מאד.

Compare to the passage from Sitrei Torah, 36-37, and Idel, "On the Secrets of the Torah," 384-85, where there is a "huge secret" that is related to the seventy languages and the combinations of letters. The huge secret is, in my opinion, the naturalist approach to all languages as having been emanated by combinations of letters from the twenty-two sounds of Hebrew; he thought that the actual Hebrew language was not essentially different from other languages. See also Hayyei ha-Nefeš, 147, as well as Morlok, Rabbi Joseph Gikatilla's Hermeneutics, 63-76.

75 See Idel, Language, Torah, and Hermeneutics, 8-11. See also Eco, The Search for the Perfect Language, 32-33. 
of cosmic generation and passing away; namely, the most natural processes that are also connected to the movement of the sphere. ${ }^{76}$

In my opinion, the great secret is that the lingua sacra-which, according to the plain sense accepted in traditional Judaism, is the historical manifestation of the Hebrew language-means, according to the secret meaning, no more than the twentytwo perfect sounds. These perfect sounds are the natural sounds of the Hebrew alphabet that can be pronounced by everyone and combined in different ways, thus generating all seventy languages. ${ }^{77}$ These letters/sounds alone are considered to be natural, so when they are pronounced perfectly, they are part of the natural human vocal apparatus. As such, they are independent of the individual's religious beliefs and ritual performances.

If I am correct, the secret of the languages can best be understood by assuming that the superiority of the historical Hebrew language is not involved here, but rather the similarity of all languages, which emerge in the exact same manner from the metaphorical Holy Language which is constituted by the twenty-two natural sounds.

Unlike the Muslim Neo-Aristotelians and the Maimonideans, Abulafia was especially concerned with the nature of language, and repeatedly resorts to phrases such as "all the languages" and "the essence of language" in relation to a secret that he does not clearly explicate. However, this secret is crucial for understanding his views in general, as we shall see below. The twenty-two sounds of Sefer Yeșirah are both ideal and natural; therefore, in principle they are not separated from other languages. Instead, the twenty-two sounds are the "mother" of all other languages; the relationship between the twenty-two sounds and other languages is a relationship between the generation of entities from the prime matter into individuation by the different types of combinations of sounds rather than a simple type of superiority or chosenness. ${ }^{78}$ This is indeed a very great secret to be kept hidden if one is operating within a religious tradition that was essentially particularist, treating the Holy Language as the historical phenomenon of Hebrew. ${ }^{79}$ Elsewhere, Abulafia sees the beginning of all languages as the Holy Language, as their mother. ${ }^{80}$

76 See Geț ha-Šemot, 20. See also Appendix A.

77 Compare to "Ševa' Netivot ha-Torah," 4, 8, and Oṣar 'Eden Ganuz, 1:9, 181-82. This is a view that is found in Abulafia's first book, Geț ha-Šemot, 38.

78 See Idel, Language, Torah, and Hermeneutics, 14. On Hebrew as the "head" (ראש) of all languages, see Oșar 'Eden Ganuz, 1:1, 26. Let me point out that in my opinion, Abulafia's description of Hebrew as the lady of the two other languages, Latin and Greek, refers to the ideal "Hebrew."

79 See Geț ha-Šemot, 38:

תזכירו בע' לשונות אין אותיותיו כי אם לשון הקודש והכל עניין אחד, אלא שזה הלשון שמוכן בו לזה היודע ואינו מוכן לזה ליז שאינו יודעו שם, לכך לזה העניין המופלג כי יש יש בו סוד גדול מאל עאד.

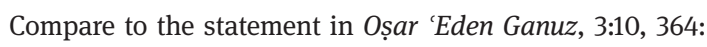

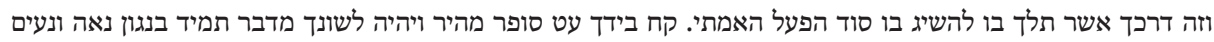

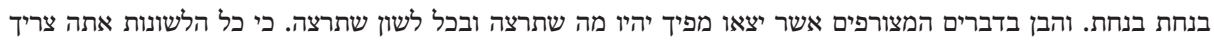
להשיבם אל חמרם הראשון.

See also the passage quoted above from Oșar 'Eden Ganuz, 51. 
Abulafia's effort to distance himself from the particularist approach is obvious in his early book Sefer Mafteah ha-Ra'ayon, where he writes at the end of the report of the infant experiment that

concerning our belief that the child was a Hebrew speaker, being in actuality a nonspeaker, this would be a very good story, for we would thereby raise the stature of our language in the ears of those who adhere to this story, although it would be an entirely false fabrication. In addition, he diminishes the stature of the proofs he uses. And as for me, it is not wise to use false claims to raise the stature of anything [...]. However, since our language is indeed of a higher quality, but for different reasons, [...] therefore, it is called the "Holy Language." ${ }^{81}$

In my opinion, the other reason, in addition to the testimony of the nations as to the priority of Hebrew, is the natural character of the Hebrew sounds, as mentioned above. According to this understanding of the nature of language, it is difficult to deny Abulafia's universal approach. Let me point out that although we do not know where Mafteah ha-Ra'ayon was written, it is quite plausible that it was not produced in Italy, but either somewhere in Spain around 1273 or a few years later in the Byzantine Empire. However, the topic of the above passage (the infant experiment) seems to point to Abulafia's earlier presence in Italy, where this issue became an important topic in Jewish sources some years later.

According to Abulafia, the single difference between the languages is not inherent in the different structures of the languages themselves, but in the nature of the nations that are speaking them and in the possible deterioration of the natural aspect of language. In any case, he indicates in his Or ha-Śekhel that if "language is conventional, speech is natural,"82 and does not exclude Hebrew from this general

80 Mafteah ha-Hokhmot, 60.

81 See Sefer Mafteaḥ ha-Ra'ayon, 24:

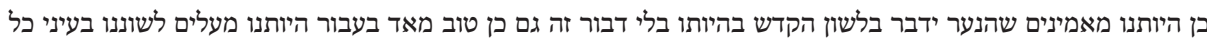

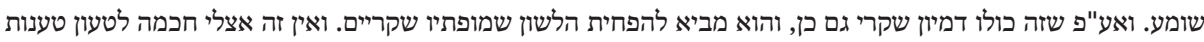

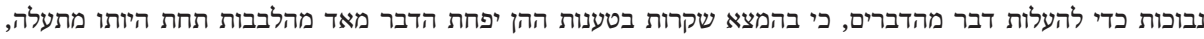
ותתהפך הכוונה בו. אך היות ולשוננו מעולה מכל לשון זה אמת מצד אחד ומופתיו הם מופתיים נראים, ועל כן נקרא היות מתלה

לשון הקדש.

See also Idel, Kabbalah in Italy, 324-39.

82 Or ha-Śekhel, 54: שאם הלשון הוא הסכמיי הדבור הוא טבעי

This means that intellection cannot ground itself in language that is conventional and, therefore, imaginary. This would also be the view of Spinoza's Treatise of the Emendation of the Intellect, par. 88-89, translated by Robert Harvey Monroe Elwes as On the Improvement of Understanding (New York: Dover Books, 1955), 37: "Words are part of the imagination-that is, since we form many conceptions in accordance with confused arrangements of words in the memory, dependent on particular bodily conditions-there is no doubt that words may, equally with the imagination, be the cause of many and great errors, unless we keep strictly on our guard. Moreover, words are formed according to popular fancy and intelligence, and are, therefore, signs of things as existing in the imagination, not as existing in the understanding." See especially Abulafia's discussion in Oșar 'Eden Ganuz, 3:6, 324, where he makes it clear that the name "Abraham" does not represent anything essential about his personality. For the views that connect Abulafia's approach to Dante's con- 
statement as he does in his later book, Imrei Šefer: "All the languages are conventional, but the Holy Language is natural". ${ }^{83}$ This parallelism between Holy Language and speech both being natural versus the conventional languages is conspicuous and at the same time quintessential for understanding Abulafia's secret of the languages.

Indeed, according to Abulafia, the cosmic Agent Intellect is most probably the primordial speech (dibbur qadmon), the source of all speech that constitutes the prime matter of the revelation. ${ }^{84}$ According to several of his texts, ${ }^{85}$ this separate intellect is the source of all the sciences of the world-and of human knowledge as well -and at the same time, it is depicted in many of his writings as the source of the seventy languages (šive'im lešonot). Šive'im lešonot is a phrase which is identical, according to gematria calculation, to the consonants in the combination of the letters of the phrase seruf otiyyot, since the two Hebrew phrases amount to the same figure, $1214 .{ }^{86}$

Again using gematria, Abulafia calculates that the consonants of the Hebrew term for the Agent Intellect (Śekhel ha-Po'el) are numerically identical to the noun Yiśra'el, since both phrases equal 541. The noun Yiśra'el is interpreted as being composed of $Y e \check{S}=310$, which means "there are," and $R a^{\prime} l$, the 231 combinations of two letters presented in some versions of Sefer Yeșirah. ${ }^{87}$ In his Or ha-Śekhel, Abulafia discusses the speech that is common to man and God, which can only mean that speech has a distinct intellectual character of its own, or that it should be understood as intellect in this context. ${ }^{88}$ This is the reason why Abulafia uses the term koah dibbri ("the speaking faculty") in many cases to refer to the intellectual faculty.

Following the theories of Sefer Yeșirah and its commentaries, the source of the forms in this world is envisioned to be identical to all of the possible two-letter combinations in the Hebrew alphabet. In Abulafia's mystical system, combinations of letters are a major component in attaining mystical experience, which is tantamount in many instances to union with the Agent Intellect. The lower linguistic activity there-

\footnotetext{
cept of forma locutionis, see chapter 4 note 49 and chapter 14 note 42 above; see also Rosier-Catach, "Sur Adam et Babel: Dante et Aboulafia," 134-37.

83 Ed. Gross, 67.

84 See Abulafia, "We-Zot li-Yehudah,” 16.

85 See Idel, Language, Torah, and Hermeneutics, 108, 142-43.

86 See Gershom G. Scholem, "The Name of God and the Linguistic of the Kabbala," Diogenes 80 (1973): 187-92; Idel, Language, Torah, and Hermeneutics, 8-11, 38-41, 108-9.

87 See Sitrei Torah, Ms. Paris, BN 774, fol. 125a, 139. See also Scholem, "The Name of God and the Linguistic of the Kabbala," 187-88; Wolfson, Language, Eros, Being, 240-41. A question can be asked whether the 231 gates (the combinations of two letters) are natural units, given their mathematical comprehensiveness or exhaustiveness; they are closer to the origin than the other combinations of letters, some of them allophones, that generate the conventional languages.

88 Or ha-Śekhel, 27-28: בכח הכרח הדבור המשותף בין האדם והאלהים. Since God cannot speak or hear, the intellectual aspect of the term "speech" in this passage is logically necessary.
} 
fore unifies the human and supernal spiritual realms, which are both conceived in linguistic terms. There is also, in my opinion, a more psychological contribution within the art of letter combination: it frees a person's thoughts by removing inhibitions related to given forms of words and allows new associations, including the resort to several words from foreign languages.

This removal is also evident in contemporary Zoharic literature, whose composition might have been related to the magical techniques of Šem ha-Doreš, the name for delivering sermons, and Šem ha-Kotev, the name for fast writing or copying of texts. It should be pointed out that the above speculation also includes a spiritualisation of the term Yiśra'el, understood in many of Abulafia's writings as being allegorically related to the cosmic Agent Intellect. The name of the Jewish nation has therefore been transposed into a reference to a universal entity related to all the acts of intellection that are not conceived as specific to this nation in the Neo-Aristotelian tradition.

The more natural and thus universal conceptualisation of the Hebrew language and the consequences that are involved in the particularist vision of religion in Judaism (for example, the unique status of the sacred scripture) may explain why Abulafia considered the natural character of the letters and the similarity of the languages that emerge from their combinations to be a theory that was dangerous and prone to endanger him, as we have seen in the passage from Oșar 'Eden Ganuz translated above. ${ }^{89}$ It should be emphasised that in Or ha-Śekhel, Abulafia describes the possibility of the special nation (implicitly the Jews) returning to a certain place after it was dispersed among other nations and spoke their languages; there, it will speak a language that combines all the other languages.

As described above, Abulafia's attitude subverts the traditional view that historical Hebrew will become the universal language in the eschaton. ${ }^{90}$ It should be pointed out that in Abulafia's many discussions of the nations, he addresses processes of dispersion, changes of leadership, and changes of languages and religions in a rather natural manner, unlike the explanation by divine voluntaristic attitude that is found in other Kabbalists. Thus, it is not just a philosophical theme that is dangerous in itself, but the application of this theme to understanding the esoteric meaning of religion that would attract protest from the traditionalist thinkers, paramountly Jewish ones who were prone to particularism.

The natural interpretation of the linguistic structure Abulafia proposes in the context of Sefer Yeșirah has been combined with the naturalistic/intellectualistic structure of Maimonides's thought and some other philosophical books that the Kabbalist studied. This combination was understood as being prone to imperil, in his view, the inner structure of traditional forms of Judaism. In a way, Abulafia expanded the continuum of intellectual entities (God, the separate intellects, and the human intellect) to the linguistic apparatus, conceived as a continuation of the intellectual

89 Oșar 'Eden Ganuz, 3:10, 364, translated above in chapter 15 note 79.

90 Or ha-Śekhel, 32-33. 
influx, also within the natural sounds. He plays on the double sense of koah dibbri, the intellectual and linguistic power, an echo of the Greek double sense of logos. Let me explore the esoteric aspect of a similar topic and discuss such a potentially dangerous consequence.

The idea that the Jewish people had been elected or chosen was part and parcel of traditional Jewish myths. This view also extends to the sacred scriptures and the Hebrew language. The meaning of chosenness was that God decided to separate the Jews from the other nations, a separation that was conceived in terms of genetic criteria; namely, the special status of the seed of Israel, Zera' Yiśra' el. ${ }^{91}$ This means that the ancient tribal extraction of people stemming from the tribe of Judah was viewed as continuing throughout the centuries. This view was dominant in Rabbinic Judaism and in the theosophical-theurgical Kabbalists and created a form of conception that assumes an ontic difference between the Jews and other nations. ${ }^{92}$

However, Abulafia adopted another understanding of chosenness: the view that some entities are to be understood as the best in their category, which does not mean, or at least not necessarily, that they have been chosen in the ordinary sense of the word. This is the reason why Abulafia plays with the various meanings of the Hebrew root BHR, which means "to choose": muvhar, or mivhar. In the context discussed above, this root means "the best of all"; however, it may also have the connotation of "the chosen" in the more traditional sense. This is quite an interesting case of equivocality, and we have seen premises that encourage a reading that is more universalistic than particularist in chapter 9 above..$^{93}$

91 See Isaiah 26:2, 28:5, 45:19, 60:21, 61:9, 64:9 65:9; and elsewhere in the Hebrew Bible 1 Chronicles 16:13; Nehemiah 9:2; and Psalms 22:23. See also Michael L. Satlow, “'Wasted Seed': The History of a Rabbinic Idea," HUCA 65 (1994): 137-75 (especially 161-62, 168, where he suggests the possibility of a Zoroastrian impact on the Babylonian Rabbis' prizing of semen). Compare these to Romans 4:16, 9:68, and Galatians 3:27-29. The phrase "seed of Israel" occurs in the oldest reference to Israel in extrabiblical sources. See David Winton Thomas, Documents from Old Testament Times (New York: Harper \& Row, 1958), 137-41. On the mixture of the seed of Israel as a sin, see Ezra 9:2, 10:19, and the discussion by Jacob Milgrom, Cult and Conscience: The Asham and the Priestly Doctrine of Repentance (Leiden: Brill, 1976), 71-73. Compare the more universalist theory of the nature of the Jewish people, grounded in an ethical monotheism, in the thought of Hermann Cohen and Emmanuel Levinas, as analysed in Kasher, High above All Nations, 178-90, 216-24.

92 On the Zoharic phrase zera' qadiša' ("the holy seed"), see Wolfson, Venturing Beyond, 27; for additional sources in Kabbalah, see Wolfson, Venturing Beyond, 36-37, 49, 54-55, 87-88, and 158-59. 93 For the question of the relationship between divine will and divine wisdom in Maimonides and his followers, see Nuriel, Concealed and Revealed in Medieval Jewish Philosophy, 41-63; Halbertal, Maimonides, 263; Arthur Hyman, "Maimonides on Creation and Emanation," in Studies in Medieval Philosophy, ed. John F. Wippel (Washington: Catholic University of America Press, 1987): 57-59; Aviezer Ravitzky, 'Al Da'at ha-Maqom: Studies in the History of Jewish Thought [Hebrew] (Jerusalem: Keter, 1991), 212-41; Vajda, Isaac Albalag, 91-129; and Isaac Albalag, Tiqqun ha-De'ot, 77-78. See also Alfred L. Ivry, “The Will of God and Practical Intellect of Man in Averroes' Philosophy," Israel Oriental Studies 9 (1979): 377-91. A reading of Abulafia from the perspective of his ongoing adherence to Maimonides's approaches to the nature of divine will, wisdom, and nature, especially to what I assume was 
Therefore, the best of the languages is not necessarily a concrete chosen language selected by an arbitrary divine act. It is not the result of the divinity's act of free will that determines or predetermines the superiority of one entity over many others. In Abulafia's thought, Hebrew is conceived as not necessarily the specific language spoken by the Jews, but rather as a natural expression of the human capacity to speak using the twenty-two natural letters, as found in Sefer Yeșirah, where the association between letters and the human vocal apparatus is obvious. The idea that this language is natural can also be found in this book: according to its first part, God created the world by means of combining letters, and according to its second part, the letters are appointed in the various realms of existence.

This concentration on language is reflected in a brief but cogent description of Abulafia found in Rabbi Solomon ibn Adret's responsum as belonging to those who are "deepening in language according to their opinion." 94 Unfortunately, we do not know who the other authors belonging to this category could be. I am inclined to identify them with the group of Kabbalists dealing with Sefer Yeșirah with whom Abulafia was in contact in Barcelona in the early 1270s. This group was highly influential in Abulafia's career as a Kabbalist. ${ }^{95}$ Indeed, Rabbi Baruch Togarmi's Commentary on Sefer Yeșirah displays a strong propensity towards linguistic speculations.

Here, there is an obvious special attitude that considers the Hebrew language to be more natural than other languages without accepting the myth that it was spoken by God to the prophets or that it was the instrument of creation of the world, as found in Genesis 1, since Abulafia prefers the combinatory account of creation at the beginning of Sefer Yeșirah. This is also the case in his attitude towards the question of which language an infant would "naturally" speak without being taught to speak at all-namely, what the innate language was-which was highly debated in the second part of the thirteenth century. Abulafia derides the view found in an epistle of his former teacher Rabbi Hillel of Verona-though without mentioning his name-which opts for the assumption that an infant would spontaneously speak Hebrew. ${ }^{96}$ In short, Abulafia's attitude as a Kabbalist whose Kabbalah is focused on lan-

the latter's esoteric position, means that the former can hardly be considered a theurgist, as Elliot Wolfson and his followers would like us to believe. See Sagerman, The Serpent Kills, 235-36, or Pedaya, "The Sixth Millennium," 67-68. This question requires a more detailed analysis that cannot be undertaken here; see, for the time being, Abulafia's statement in his early book Mafteah ha-Ra'ayon, 5 , as well as my discussion in chapter 17 below. On the connection between the denial of the concepts of divine will and the pre-eternity of the world, see the discussion about Al-Ġazāli and Averroes in van den Bergh, The Incoherence of Incoherence, 1:224-66.

94 Responsum 1, no. 548: מעמיקים בלשון לדעתם.

95 See Idel, "Sefer Yetzirah and Its Commentaries," 527-31.

96 See Idel, Kabbalah in Italy, 327-33; Irene E. Zwiep, Mother of Reason and Revelation: A Short History of Medieval Jewish Linguistic Thought (Amsterdam: Gieben, 1997), 172-77; and Rosier-Catach, "Sur Adam et Babel: Dante et Aboulafia," 124-32. See also Gad Freudenthal, "Dieu parle-t-il hébreu? De l'origine du langage humain selon quelques penseurs juifs médiévaux," Cahiers du judaïsme 23 (2008): 4-18. 
guage is nevertheless much more naturalistic, being far more consonant with the way Rabbi Zerahyah Hen, who was active in Rome in the years Abulafia was there, understood the story in comparison to the more particularist approach as found, for example, in his former teacher's epistle. ${ }^{97}$

I would therefore say that Abulafia's allegorical radicalism dramatically complicates the widespread scholarly picture of Kabbalists who are conceived as being on the opposite conceptual pole to Maimonidean allegorical thinkers. A better assumption would be that it is quite plausible that the latter were triggered by Abulafia writing down the secrets of the Guide. ${ }^{98}$ It is even more plausible that Abulafia and his sources or circle can be modestly conceived as one of the triggers for the philosophically oriented commentators, ${ }^{99}$ such as Rabbi Joseph ibn Kaspi ${ }^{100}$ and Rabbi Zerahyyah Hen. In one of his epistles, Rabbi Zerahya Hen reacted to the magical-mythical interpretations of the term Ben probably found in a lost commentary on the Guide.

Abulafia, however, does not seem to react to what may be called radical Maimonideanism, as Yossef Schwartz suggests, since he was already one of the most radical among them. So, for example, he is conceptually much closer to Rabbi Zerahyah than to Rabbi Hillel insofar as the infant experience is concerned, as we mentioned above. ${ }^{101}$ This fact shows that the possible direction of impact is far from being clear; it is possible that both directions are equally plausible.

Moreover, to strengthen my point as to the independence of Abulafia's dealing with the secrets of the Guide, it should be mentioned that he wrote his commentaries in the context of his oral teaching of these secrets to some of his students, perhaps as a response to their request, as he claims. Therefore, we have at least one good reason for his literary activity, as he specifies it in two of his commentaries. ${ }^{102}$ Moreover, the assumption that the revelation of the secrets is related to imminent redemption offers

97 I see no historical evidence for Hames’s hypothesis that Zerahyah’s reaction to Abulafia’s coming to Rome might have been so "negative as to include warning his Christian contacts against him." See Hames, Like Angels on Jacob’s Ladder, 98.

98 See Yossef Schwartz, "Magic, Philosophy and Kabbalah,” 114.

99 See the different hypothesis formulated in Idel, "Maimonides's Guide of the Perplexed and the Kabbalah," 219, where, following a suggestion from Steven Harvey, I claim that the impact of esoteric mystical and magical traditions on the philosophers/commentators was both a challenge and a trigger to react.

100 Idel, “Abraham Abulafia's Works and Doctrine," 12. I refer here to the important observation of the editor of ibn Kaspi's two commentaries on the Guide, Salomon Z. Werbluner, 21-22, note, who already explicitly referred to Abulafia's commentary on the Guide. Compare also Abulafia's discussion of the damage that the teachings of extreme disciples of Maimonides's thought inflicted, according to his Hayyei ha-Nefeš, Ms. Munich, 408, fol. 47a, 81. Compare too with ibn Kaspi's discussion in his commentary on Proverbs 1, 'Aśarah Kelei Kesef, 1:19. It should be pointed out that a similar attack on addressing the radical followers of Maimonides, who damaged his image so much so that he is sometimes envisioned as a champion of Jewish traditionalism, is found in Rabbi Joseph Ashkenazi, Commentary on Genesis Rabbah, 80.

101 See above chapter 16 note 97.

102 This is obvious in Sefer Ge'ulah, 32, and in Sitrei Torah, 17-19. 
another plausible reason for his independent and intense literary activity. In any case, in what I propose to see as the introduction to Abulafia's first commentary on the secrets of the Guide, he expressly says that he was told in a revelation to write something that no one had written before. This statement minimises the possibility that he was reacting to other commentaries. ${ }^{103}$

\section{The Secret of the Two Tablets of Stone}

Above, we analysed some secrets in Abulafia's esoteric thought. He resorts to the terms "secret," sod, and seter more than two thousand times. There is no way to analyse all these occurrences, even in a study especially devoted to his esotericism. Nevertheless, let me turn to what I conceive to be a few of the other major secrets in his esoteric thought.

In paragraph [a2] of the above text, there is quite an unusual statement regarding the biblical tablets of stone, which are described as possibly possessing an esoteric meaning: "The two tablets of stone, either if this is according to the plain sense alone or if it should be understood in both the exoteric and the esoteric senses. And either both senses are true, or one of them."

The last possibility of the three mentioned here, to the effect that only one of the two possible meanings is the correct one, is a rather surprising one in medieval literature, but not so much in this specific case. In Abulafia's axiology, the esoteric meaning is conceived as superior or, presumably, truer. It is obvious, by dint of elimination, that the last words can only be understood as referring to the possibility that the esoteric sense alone is true.

Indeed, in one case in his commentary on Hotam ha-Hafțarah, which is the final part of his prophetic books, we read that a certain issue "was, according to its plain sense, overt and necessary, and its secret [sense] is for a true reason." "104 The plain sense is conceived, therefore, as being necessary for the vulgus's low level of understanding, though it is not necessarily true. ${ }^{105}$ This means that the plain sense of the verse about God writing the letters of the Ten Commandments on the tablets of stone with his finger should be treated as quite unimaginable within the framework of Abulafia's Maimonidean theology, which often describes God as a separate intellect, or as the Necessary Existent, in the vein of the theologies of Avicenna and Maimo-

103 See Idel, “Abraham Abulafia’s Works and Doctrine,” 10.

104 In Mașref ha-Śekhel, 117:

הוא עניין גלוי מסתרי התורה שהיה כפשוטו לעניין נגלה הכרחי, ובנסתרו לעניין אמיתי, ראוי להעלימו מכל סכל. In Maimonides's terminology, the necessary does not automatically mean something good in itself; here, the association with the plain sense only confirms the negative aspect.

105 See Mașref la-Kesef, Ms. Sason 56, fol. 33b: והשקר נגלה בם והאמת נעלמת (The lie is revealed in them and the truth is hidden"). Compare to his Mafteah ha-Hokhmot, 32: דרך המחשבה ההמונית ("The path of the vulgar thought"). 
nides. ${ }^{106}$ Consequently, such an anthropomorphic description constitutes a great theological quandary which must be solved, and in this context, the concept of secrecy is explicitly mentioned. ${ }^{107}$

The philosophical concept of divinity that Abulafia confesses to having studied in some places and to which he refers as constituting the main "objective" framework for his mysticism is in the vein of the sequence described by Hans Jonas: between a more philosophical, "objective" framework that preceded the emergence of a certain type of mysticism and its interiorisation. ${ }^{108}$ This conclusion leaves us with the possibility that at least in some cases, Abulafia attributes religious authority solely to the esoteric sense of this biblical episode, perhaps the only possible one from his theological point of view, especially when the plain sense is so problematic. Such a view that aligns veracity and authority with the esoteric alone is quite rare and is certainly problematic in Rabbinic Judaism, as it also was in Ismā'îliyyah, and it was formally condemned by Rabbi Isaac of Acre. ${ }^{109}$

For example, what would the esoteric meaning of the biblical verse on the finger of God and the tablets be, according to Abulafia? Maimonides had already addressed the quandary generated by the anthropomorphic image of the finger of God. ${ }^{110}$ In his Sefer ha-Melammed, most probably written in 1276, perhaps in Patras in the Greek territories, Abulafia writes:

106 Abulafia combines an Avicennian and Maimonidean view of God as the Necessary Existent with the necessity of a separate intellect as a Prime Mover, which is more Averroistic. Averroes's vision of God as the Necessary Existent runs through many of Abulafia's books, from his earliest writings (Get ha-Šemot, 4, 34), the middle period of his literary activity (Or ha-Śekhel, 15, 71, and the commentary on Sefer Yeșirah, 21), through to his last writings (Sefer ha-Hešeq, 34, and Imrei Šefer, 60 and 190). This assumes some form of hierarchy, which is evident, for example, in his Hayyei ha-Nefeš, 20. See also his untitled short treatise found in Ms. Sassoon 290, 233. For Maimonides's source for the Necessary Existent, see Warren Zev Harvey, "Maimonides’ Avicennism," Maimonidean Studies 5 (2008): 110-16; for God as an intellect, see Harvey, "The Mishneh Torah as a Key to the Secrets of the Guide," 22-24. Abulafia sees God as the immobile mover (cf. Geț ha-Šemot, 13) and he also uses this concept in other cases when speaking about the human intellect.

107 See Levi ben Avraham, Liwyat Hen, 250-63. See also Dov Schwartz, "Remarks on the Late 13thCentury Debate on Prophecy and Esotericism" [Hebrew], in Religion and Politics in Jewish Thought, 1:263-285.

108 See Hans Jonas, "Myth and Mysticism: A Study in Objectification and Interiorization in Religious Thought," in Hans Jonas, Philosophical Essays: From Ancient Creed to Technological Man (Chicago: University of Chicago Press, 1974), 291-303; see also Franz Rosenthal, "Ibn 'Arabi Between 'Philosophy' and 'Mysticism.' 'Sufism and Philosophy are Neighbours and Visit Each Other,'” Oriens 31 (1988): 1-35, and Idel, The Mystical Experience, 138.

109 See Idel, Language, Torah, and Hermeneutics, 188, note 5, and Rabbi Isaac of Acre's passage translated in Idel, "Maimonides and Kabbalah," 73, note 153, which seems to be a diametrically opposite formulation in comparison to the hint found in Abulafia.

110 For Maimonides's own discussions of the finger of God, see Guide of the Perplexed, 1:46, Pines, 1:100-101; 1:66, Pines, 1:160. 
And indeed the existence of the twenty-two letters that are engraved in the voice, [and] extracted from the wind, [and] fixed in the mouth in five places ${ }^{111}[\ldots]$ that in man are found in a natural existence and on the tablets [of stone] in an artificial, conventional existence. ${ }^{112}$ And this is the case in every script and every scripture and every tablet, except for the script and the scripture on the tablets that were created during the twilight; ${ }^{113}$ it is written that ${ }^{114}$ "and the tablets were the tablets of Elohim and the writing was the writing of Elohim, engraved upon the tablets," and elsewhere it was written ${ }^{115}$ "and I will give thee the tablets of stone and the Torah and the commandments which I have written that thou mayst teach them" together with what was written in the first verse, "and the tablets are the tablets of Elohim," and then he wrote "and the writing is the writing of Elohim engraved upon the tablets," and he also said that "they were written by the finger of Elohim. From all these three things, you will understand that it is written Elohim [which refers to] natural deeds [...]. You should know that the writing and the scripture and the tablets are indubitably natural deeds like all the others [mentioned] in the account of creation, as the Rabbi said: ${ }^{116}$ "Indeed, Onqelos commented when he commented on $E s ̦ b a^{\prime}-E s ̦ b a^{\prime} a^{\prime}$, and he did not interpret it against its plain sense, because of a wondrous secret." And it is not hidden from me that this was hidden from the Rabbi, as he mentioned there. But it seems to me that he said so only in order not to disclose the secret to the multitude. ${ }^{117}$

Following Maimonides's statement concerning the tablets conceived as divine deeds and as natural, Abulafia elaborates on the biblical verses that may be the background of Maimonides's equation between divine and natural deeds. The recurrence of the divine name Elohim in the three instances in the Hebrew Bible where the tablets and the writing on them are mentioned, as well as in all the contexts where the

111 Sefer Yeșirah, 2:6.

112 This is a sharp assumption as to the conventionality of writing on tablets, which differs from his own assumption found elsewhere in his writings that writing on tablets is natural. For the attack on the theory of the conventionality of names in Hebrew, see Rabbi Joseph Ashkenazi, Commentary on Genesis Rabbah, 142. For Maimonides's view of Hebrew as a conventional language, see Guide of the Perplexed, 2:30, Pines, 2:357-358, and Stern, "Maimonides on Language and the Science of Language," 197-99.

113 Cf. BT, Pesahim, fol. 54a.

114 Exodus 32:16.

115 Exodus 24:12.

116 Namely, Maimonides in Guide of the Perplexed, 1:46, Pines, 1:100-101, or 1:66, Pines, 1:160.

117 Sefer ha-Melammed, 24-25:

הנה אם כן מציאות כ"ב אותיות שהם חקוקות בקול חצובות ברוח, קבועות בפה בחמשה מקומות [...] הם נמצאות באדם

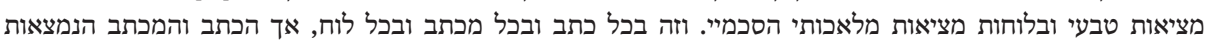

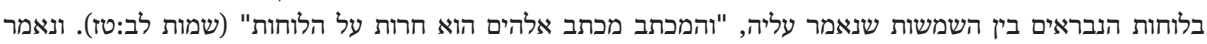

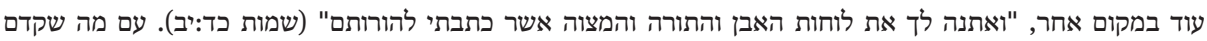

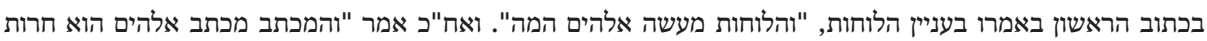

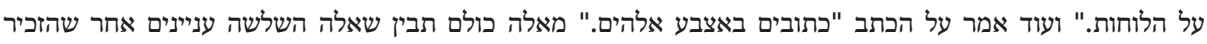

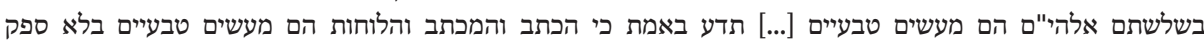

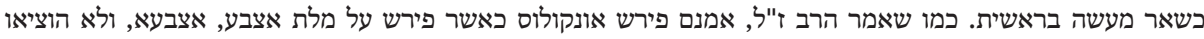
מפשוטו, הוא לסוד נפלא. ולא יעלם אצלי שמרי שנעלם זה מן הרב כמו שזכר שם שם, אבל נראה שלא אמר זה זה אלא כדי שלא

יתגלה הסוד להמון.

This argument is reminiscent of the manner in which he treats ibn Ezra's rejection of the use of gematria, as discussed in chapter 7 above. 
finger of God is mentioned in the same book, is reminiscent of the recurrent and exclusive usage of this name in the first chapter of Genesis, designated in the translated passage as the "account of creation." Thus, a nexus has been created between the specific divine name used in connection to primordial beginnings and the tablets.

Abulafia adds to these parallels another "natural" entity: the letters of the Hebrew alphabet as spoken, the twenty-two sounds, since they are also described as engraved in Sefer Yeșirah. This connection between nature and the name of God can be understood as a divinisation of nature, though it is at the same time a naturalisation of a certain aspect of God or his activity, designated by the name Elohim. ${ }^{118}$ Thus, unlike other alphabets and tablets that are conceived as artificial and/or conventional, in the case of the tablets given to Moses, Abulafia speaks about a natural phenomenon, which means that there was no act of writing on the tablets in the moment of their revelation, since the "writing" was found there primordially. Therefore, there is no conceivable role for the anthropomorphic "finger of God" writing down the commandments at a certain historical moment. In other words, the priority of the sonorous aspects of the original language over the written and posterior forms is obvious.

Such a naturalistic approach to these biblical episodes is presented as a secret that cannot be revealed to the multitude, despite the fact that Maimonides himself did not explain or hint at the reason why the Aramaic translator did not replace the anthropomorphic finger with something else. For the sake of our discussion in the previous chapter, let me emphasise again the naturalistic approach to Hebrew writings and, implicitly, to language as such. Beyond those exegetical and philosophical moves, for Abulafia's mode of thinking, there is one more reason to assume the correctness of Maimonides's naturalistic interpretation: the consonants of the name Elohim, which was related to the acts of creation in Genesis 1, amount in gematria to 86, like the word ha-Teva', "nature." 119 From the 1270s, this gematria became a clas-

118 See also the interesting discussions where the categories of divinity and nature are mentioned together in Abulafia's Hayyei ha-Nefeš, 77, 79. Compare, however, Abulafia's propensity to naturalise the tablets of stone to the strong tendency to mythologise by identifying them with the breasts of the female divine power (the Shekhinah) in the latter layer of the Zoharic literature; see Biti Roi, "The Myth of the Šekhina in Tiqqunei ha-Zohar: Poetic, Hermeneutic and Mystical Aspects” [Hebrew] (PhD diss., Bar-Ilan University, 2012), 266-68 See also chapter 26 note 157 below.

119 For more on some of these issues, see Moshe Idel, "Deus sive Natura-The Metamorphosis of a Dictum from Maimonides to Spinoza," in Maimonides and the Sciences, eds. Robert S. Cohen and Hillel Levine (Dordrecht: Springer, 2000), 87-110; Carlos Fraenkel, "Maimonides’s God and Spinoza's 'Deus sive Natura," Journal of the History of Philosophy 44 (2006): 169-215; Wolfson, "Kenotic Overflow and Temporal Transcendence," 185-86. To Elliot Wolfson's mind, however, Spinoza's source might be Jacob Boehme! See his Language, Eros, Being, 8. See also Henry Malter, "Medieval Hebrew Terms for Nature," in Judaica: Festschrift zu Hermann Cohens siebzigstem geburtstage, eds. Ismar Elbogen, Benzion Kellermann, and Eugen Mittwoch (Berlin: Bruno Cassirer, 1912), 253-56, and Fritz Meier, "The Problem of Nature in the Esoteric Monism of Islam," in Spirit and Nature: Papers from the Eranos Yearbooks, trans. Ralph Manheim, ed. Joseph Campbell (New York: Pantheon, 1954), 153-54. 
sic in various forms of Jewish literature up to Hasidism, although scholars of Spinoza did not always take the implications of this numerical linkage very seriously.

In my opinion, we may guess the significance of this famous gematria in Abulafia's thought, which is most plausibly the principal source of this numerical linkage. According to Abulafia, "Elohim are the supernal powers that bind all of existence."120 A somewhat similar position can also be found in the short Commentary on Ma'aśeh Berešit by one of the early writings of Abulafia's disciple Gikatilla:

The word Elohim is an appellative ${ }^{121}$ corresponding to certain acts and as long as the Holy One, blessed be He, does not act, there is no appellative of Elohim, since the appellative is always close to the act and He, blessed be He, is never called an appellative except in the moment of action [...] See, at the beginning of creation, Elohim [is found], and this appellative was given to Him because of the act of nature in order to announce that this appellative would now be innovated by the innovation of the natures. ${ }^{122}$

The two last passages show that the equation Elohim = ha-Teva' does not assume a full pantheistic vision, still less a panentheistic one, since there is also a level or a moment of the divinity's existence before the act of creation; it is only the latter, which is tantamount to nature, that is identical to Elohim. I assume that Abulafia's view differs from Gikatilla's since the latter emphasises the belatedness of the appellative much more than his teacher does. This antecedence of some names is the rea-

120 Sefer Mafteah ha-Šemot, 31: אלהים שהם הכחות העליונים הקושרות כל המציאות. Compare to the introduction to Mafteah ha-Hokhmot, 39, which includes a description of the role of the soul in the human body, and also Maimonides's Guide of the Perplexed, 1:72, Pines, 1:187-89, especially his description of nature. See also note 47. Let me point out that despite this identification, Abulafia is less concerned with learning about God from nature, as is the case with Maimonides, whose emphasis is much more on learning from the divine name. The Kabbalist was much less concerned with amor mundi than the Great Eagle.

121 In Hebrew, Kinnui amounts in gematria to 86, like ha-Kisse', Elohim, Nivdal, and ha-Teva' . This identical series of gematrias shows how close Gikatilla was to Abulafia's Kabbalistic method. See also the next footnote.

122 Ms. New York, JTS 2156, fol. 39a:

מלת אלהים כינוי לפי פעולות ידועות וכל עוד שאין לש"י פעולה אין שם כינוי אלהים כי הכינוי סמוד הוא לפעולה לעולם

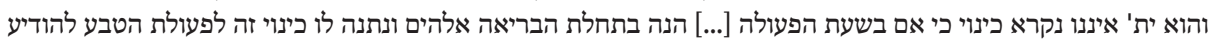

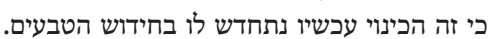

For other passages for the same view in Gikatilla's early writings, see Idel, "Deus sive Natura," 93-96, especially his view in Ginnat Egoz, 34: "The creation of the world is the act of nature, whose secret is Elohim, since nature is the nature of the throne [...]. You should understand that the name Elohim emerged with the creation of nature, whereas the Tetragrammaton did not emerge with the creation of the world, since it is [a name] unique to Him." I wonder whether this emphasis on innovation is a reaction to the view mentioned on above, which discusses the pre-eternal nature of the unifying power. See the anonymous Eškol ha-Kofer, a Kabbalistic treatise close to the views of the early Gikatilla, found in a unique manuscript Ms. Vatican, 219, fol. 10a. For the resort of another of Abulafia's students to even a longer series of gematria amounting to 86, see the anonymous treatise Ner Elohim, 46: והמלה אלהי"ם, הוא י"ה מלא, ואם הטבע, כנוי, נבדל, מבדיל, הכונה, נקרא אלהי"ם פ"ו שסודו הכסא, ונסתרו . This list is reminiscent of Judah Alboțini’s discussion in Sullam ha-'Aliyyah, 56. 
son why, as we shall see in chapter 17 below, the other divine names, which point to a more sublime aspect of divinity, are capable of changing the natural order.

Abulafia concisely formulates his conclusion in a later work, Sefer ha-Hešeq: "The tablets [of the Law] are a homonym for natural internal issues-since according to the atbash device, tablets [in $L H T$, according to the elliptical biblical spelling without the vowels] are tantamount to [the consonants of] Kisse' ["throne"], which [in gematria] is Teva ' "nature"]-and for external issues, which are the tablets of stone."123 Abulafia combines two basic forms of esoteric interpretation: the philosophical one, grounded in the assumption that the equivocal meaning entails some hidden message, and the linguistic exegesis. He introduces the atbash technique of coding and decoding-namely, the changing of letters by substituting one letter with another according to the inverse order of the letters in the Hebrew alphabet-in order to hint at the meaning of the tablets; namely, that they are the Seat of Glory. ${ }^{124}$ He then resorts to the gematria that connects tablets to nature; namely, that the tablets of stone are to be considered as a natural phenomenon.

The exegetical techniques are, however, auxiliary to the main cognitive act: the interpretation that depends on the philosophical approach, namely, that the divine seat is nature. The last move of recognition is, therefore, indispensable: while the linguistic techniques dissolve the existing linguistic structures that convey the plain sense, dealing with imaginary topics, it is by means of the allegoresis based on philosophical concepts that new meanings dealing with intellectual matters are introduced into the interpretation of linguistic material. ${ }^{125}$ This is an example of exegetical ingenuity that strengthens Maimonides's view on the divine/natural character of the tablets of stone in an original manner, which would doubtless not be acceptable to the Great Eagle. ${ }^{126}$

In more general terms, this is the role of philosophy in exegesis, be it of the sacred scriptures, of the texts written by Abulafia himself, or of the contents of his experiences: to introduce a spiritual meaning into the concrete, plain sense of the

123 Ms. New York, JTS 1801, fols. 19b-20a, ed. Gross (Jerusalem: 2002), 39-40. See also fol. 8b and Sitrei Torah, 34.

124 This explanation is found in Ashkenazi sources and perhaps even earlier; in any case, it is present long before Abulafia. See Idel, Language, Torah, and Hermeneutics, 168-69, notes 77 and 80; Elliot R. Wolfson, “The Mystical Significance of Torah Study in German Pietism,” JQR 84 (1993): 75-76. See also Ms. Cambridge, Add. 644, fol. 19b; Rabbi Bahya ben Asher's Commentary on the Pentateuch, on Exodus 31:18; and Sara Offenberg, Illuminated Piety: Pietistic Texts and Images in the North French Jewish Miscellany (Los Angeles: Cherub Press, 2013), 140, note 48.

125 See Idel, Language, Torah, and Hermeneutics, 100-103. Compare also to my "On the Meanings of the Term “Kabbalah,” 61-68.

126 See, however, Wolfson, Language, Eros, Being, 204. He describes my association of divine and natural in Abulafia, which differs from his vision and that of the other Kabbalists, as "gratuitous." His reading is predicated on a simple logical fallacy: if two Kabbalists use the same term ("divine") in the context of language, they also, according to his reading, mean the same thing; this is the reason why there are no great differences between Abulafia and other Kabbalists. 
words. In fact, we may speak of two registers or levels of interpretation: one stemming from Ashkenazi sources that may be called the deconstructive approach, which atomises the words of the texts into individual letters, and another, higher, allegorical one, which reunifies and regroups the letters according to a new order and infuses the philosophical sense, namely allegoresis, which originates in the falāsifah. Moreover, though Abulafia's various definitions of prophecy are essentially Maimonidean with some intersections of linguistic elements, the belief that it is possible to attain prophecy in the present may have something to do with the presence of several "prophets" in the Ashkenazi regions of Germany and France in the first part of the thirteenth century. ${ }^{127}$

According to the last passage, the tablets also stand for the inner, spiritual aspects of man: the tablets of the heart, which on the one hand are the intellectual and imaginative faculties, ${ }^{128}$ both designated as nature, and on the other are external objects. Since the two key concepts referred to in the passage from Sefer Geț ha-Šemot (nature and throne) also occur in the passage from Sefer ha-Hešeq, it seems reasonable to apply the exegetical principle of homonymy from one discussion to the other and to articulate Abulafia's secret about the meaning of the material entities in the Bible as pointing inward to the spiritual nature. What we learn from these passages as to the meaning of the hint in paragraph [a2] is that Abulafia interpreted the biblical episode as esoterically dealing with an inner experience, which means that the tablets of the heart are conceived as the esoteric meaning of the biblical tablets of stone. This is an allegorisation that goes far beyond Maimonides's discussions of the tablets.

Let me demonstrate at the end of this discussion a rather explicit recognition that there is a great secret involved in Abulafia's treatment of the writing of the tablets. In a continuation of the first quote I provided in this chapter (from Sefer ha-Melammed), Abulafia writes:

Since this is so, we should believe that the Torah testified to its existence; namely, the existence of the writing on the tablets being natural similarly to all the other [parts of] the account of creation. And the author of the first and last intention who has hidden and concealed his secrets ${ }^{129}$ from the hearts of the people who make efforts to stand in the world of falsehood and to prolong their days in it in vain should be praised. ${ }^{130}$

127 See Moshe Idel, “On Rabbi Nehemiah ben Solomon the Prophet's Commentaries on the Name of Forty-Two and Sefer ha-Hokhmah Attributed to Rabbi Eleazar of Worms" [Hebrew], Kabbalah 14 (2006): 157-58. I elaborate on this topic in "Prophets and Their Impact in the High Middle Ages." 128 See Idel, Language, Torah, and Hermeneutics, 16, 42-46, and the pertinent footnotes. I shall not repeat here most of the material that I have already examined there.

129 In this text, Abulafia resorts to both sod and seter without distinguishing between them as he did in the passage from Mafteah ha-Hokhmot.

130 Sefer ha-Melammed, 26:

אחר שהעניין כן נאמין למה שהעידה התורה עליו במציאותו ר"ל בהיות מציאות המכתב בלוחות טבעי כשאר מעשה

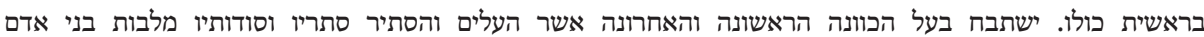
המשתדלים לעמוד בעולם השקר ולהאריך בו ימים לשוא. 
This small exercise hints at a direction that should be followed insofar as other aspects of the discussions in the passage from Or ha-Śekhel-which means the ultimate meaning, which is the esoteric, conceived as the most important one-deal with the inner experience of the intellect and other inner human faculties (or according to another interpretation, with the brain and the heart) ${ }^{131}$ and are therefore understood to be simultaneously individualistic-though not particularistic-and universal.

\section{Changing Nature by Divine Names}

The naturalist approach we dealt with in the previous chapter that elaborates on Maimonides's breakthrough within the Jewish framework is coupled with another approach. This approach resorts to the very same set of terms discussed above. Abulafia describes the three divine names that have the ability to change the order of nature in his first book as "divine [Elohiyyim] [and they] change nature [Teva $],{ }^{132}$ [since they] are the throne [ha-Kisse'] and this is the secret of [the verse] ${ }^{133}$ 'It is the Finger of God' [Eșba' Elohim]; namely, the finger changes nature by virtue of the mentioned Elohim, which is the attribute of judgment." ${ }^{134}$ In this context, the Kabbalist hints at the numerical values of three divine names: the so-called name of 72 letters, Adonai [=65], and the Tetragrammaton [= 26], which amount to 163, as does Eșbac

This means that it is possible to change the course of the nature that was created by the name Elohim through a resort to three other divine names that are understood as preceding the term "finger" in the biblical verses. Thus, what Maimonides did not

131 See Language, Torah, and Hermeneutics, 44, where the gematria kisse' $=86=$ lev u-moah is discussed according to Sefer Ge'ulah, 11. For the gematria of moah va-lev, which occurs in other places in Abulafia's writings, see the discussion of the meaning of the phylacteries in chapter 26 below.

132 Teva ' and Kisse', which amount to 81, are often related in Abulafia's writings and in the early writings of Rabbi Joseph Gikatilla. See Idel, "Deus sive Natura” and Ms. Firenze, Laurenziana, Plut. II. 48, fol. 70b, where these two entities are described as comprising "heaven and earth and their hosts." On Kisse' and Teva', see also Ms. Firenze, Laurenziana, Plut. II. 48, fol. 75b and fol. 78a, where Kisse', Teva', and Anokhi are mentioned together. Compare also to the Abulafian passage from Ms. Paris, BN 770, fol. 208a to be translated immediately below in this chapter. On the incorporeal nature of the divine seat, see Or ha-Śekhel, 72. For Gikatilla, see Ginnat Egoz (Hanau, 1615), fols. 5cd, 12d, 13a, 13b. Both may draw, as Warren Zev Harvey has remarked, on Maimonides's distinction in the Guide, 1:9, Pines, 1:34-35, where "throne" refers to the eternal heavens and "nature" refers to the sublunary world of generation and corruption (i.e., the earth). Interestingly enough, this gematria, recurring so many times in the Kabbalah of Abulafia and of that of the early Gikatilla, disappears in the latter's later theosophical writings as part of an axis change related to the different profound structures that inform his two stages: natural/linguistic in the first period and the divine sphere for the later period.

133 Exodus 31:18.

134 Geț ha-Šemot, Ms. Oxford, Bodleian 1682, fol. 101b. On this work by Abulafia, see Idel, “Abraham Abulafia's Works and Doctrine,” 4-5. On the finger of God in Abulafia, see also Idel, Absorbing Perfections, 260-61. 
do (to explain the meaning of the divine finger in a separate lexicographical chapter) is supplied by Abulafia. Here, we can discern the intersection between the philosophical interpretation and the Kabbalistic one that is oriented towards divine names: the divine finger that may change nature is not an anthropomorphic entity, part of the divine body, but actually something divine that is constituted from the names of God that are conceived as superior to the name Elohim, related as it is to the structure of nature.

The assumption that it is possible to change nature by means of divine names is a continuation of a view about the incantation of the supernal worlds by means of languages that is found in the Commentary on Sefer Yeșirah by Abulafia's teacher Rabbi Baruch Togarmi. ${ }^{135}$ In an anonymous text that I have shown to have been authored by Abulafia and which is found in manuscripts together with Togarmi's Commentary, there is an interesting presentation to the effect that

\begin{abstract}
the secret of the first $\operatorname{man}^{136}$ that rules over all the parts of language by virtue of the knowledge of the mentioned name [...] and rules by dint of the power of the mentioned name over all the natures in the world, [...] is the secret of Kisse', as I told you in connection to Anokhi, and this is the reason why He swears to whomever conjures me, by the power of this name as it is appropriate, to enact whatever he wants to do by changing the nature of all the naturata, and the sign of the letters of this name amounts to the number Qayyam, ${ }^{137}$ out of the 613 commandments, and the calculation and letters are Anokhi Qayyam, ${ }^{138}$ whose secret is $R a^{\prime} l,{ }^{139}$ whose meaning is Arkhi which in Greek is Rešit. ${ }^{140}$
\end{abstract}

135 See my analysis in "Incantations, Lists, and 'Gates of Sermons,"” 503-4. For the change of nature by means of the divine name, see also Rabbi Joseph Gikatilla, Ginnat Egoz, 337.

136 By comparing this text to the next one, in which the Messiah is mentioned in a similar context, we may assume that the first man is the Messiah. See chapter 10 note 188 above.

137150 is the number of combinations of the letters of the Tetragrammaton.

138 On the term qayyam as parallel to the monad and "idea," see the Pythagorean material discussed by Yitzhak Tzvi Langerman, "The Astral Connections of Critical Days: Some Late Antique Sources Preserved in Hebrew and Arabic,” in Astro-Medicine: Astrology and Medicine, East and West, eds. Anna Akasoy, Charles Burnett, and Ronit Yoeli-Tlalim (Florence: SISMEL, 2008), 106.

139 The number of the combinations of two letters, according to Sefer Yeșirah.

140 Ms. Paris, BN 770, fol. 208a, Ms. New York, JTS 1884, fols. 3b-4a:

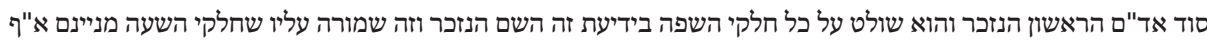

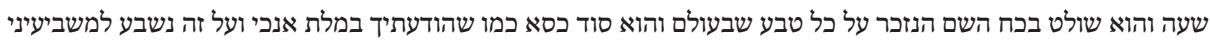

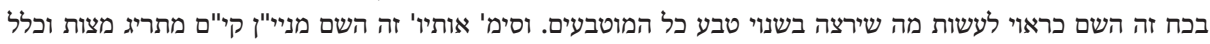

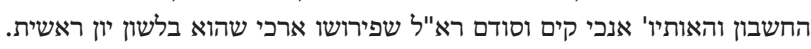
On this text and its affinity to Abulafia, see Idel, “Abraham Abulafia's Works and Doctrine,” 30. On multilingual gematrias, see my "Multilingual Gematrias in Abraham Abulafia." For a parallel discussion, see the passage from Ms. Firenze, Laurenziana, Plut. II. 48, fol. 70b, mentioned above, as well as Sitrei Torah, 71 . These parallels suffice in order to show how close the anonymous texts found in these few manuscripts are to Abulafia's identified books. On the gematria Anokhi $=$ Kisse $^{\prime}=$ Teva $^{\circ}=81$, see the early text by Gikatilla, Commentary on Ma'aśeh Berešit, found in Ms. New York, JTS 1891, fol. 70ab, translated in the previous chapter. See also the book from Abulafia's school, Ner Elohim, 46: והמלה אלהי"ם הוא י"ה מלא ואם הטבע כנוי נבדל מבדיל הכונה נקרא אלהי"ם פ"ו שסודו הכסא ונסתרו אכסה. כי "כוס 
The "mentioned name" is the Tetragrammaton, whose four letters were permuted earlier in the truncated untitled text. In this instance, the name that changes nature differs from what we have seen above, but the principle is the same. The two gematrias that inform the passage are Anokhi $=$ Kisse ${ }^{\prime}=$ Teva ${ }^{\prime}=81$ and Anokhi Qayyam = $R a^{\prime} l=A r k h i=231 .{ }^{141}$ We may assume that the reference to the Greek term arche has something to do with the creation of the world, reminiscent of the first chapter of Genesis, which can be altered by resorting to the powers of the divine name.

By using the terms Berešit and $R a^{\prime} l$, Abulafia combines the biblical account of Genesis with that of Sefer Yeșirah. This is also the case in another of his untitled texts extant in Ms. Firenze Laurenziana, where he writes that "the powers of the special name are the tools of the Messiah [in order] to change natures by their means, since its powers are over Adam, Lion, Ox, Eagle,"142 a view that reverberates elsewhere in the same treatise, where it is written that "the Messiah of the Lord will rule over the entire chariot, in accordance with the will of God."143

Thus, though diminishing, and perhaps even obliterating, the role of divine intervention in the revelation connected to the tablets of the Law, Abulafia enhances the possibility of the human knower of the divine name (the prophets or the Messiah) changing the course of nature. It should be emphasised that the power of the names is mentioned along with elite figures and that it is for the sake of redemption, not for magical purposes as the Rabbis used it, which is an enterprise that he criticises fiercely. By mentioning nature, Abulafia continues a tradition found in Abraham ibn Ezra, who was influenced by views of Al-Ġazālī and Avicenna, as to the possibility of changing the course of nature by cleaving to the supernal realm which, in their view, is universal. ${ }^{144}$ Moreover, according to two testimonies found in the writings of Flavius Mithridates, Abulafia performed miracles in Palermo. ${ }^{145}$

To frame it in a more general manner: while Abulafia was interested in both external and, more importantly, internal nature, the latter being imagined to affect the former or external nature, the theosophical Kabbalists assumed the centrality of the divine realm for their theurgical activity. These two distinct foci, nature versus divine, differ in quite a dramatic manner; they define the nature of the profound structures

\footnotetext{
Due to Gikatilla's influence, these gematrias also occur in Rabbi Hananel ben Abraham Esquira, Sefer Yesod 'Olam, Ms. Moscow, Guenzburg 607, fol. 79b.

141 See also in his Sitrei Torah, 71: טבע קים בסוד רא"ל.

142 Ms. Firenze, Laurenziana, Plut. II. 48, fol. 91a:

וכחות השם המיוחד הם כלי משיח לשנות הטבעים בם כי כחותיו הם על אד"ם ארי"ה של שו"ר נש"ר.

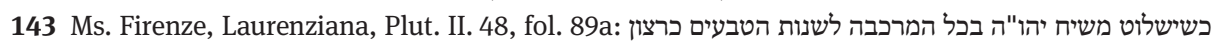
השם. See also fol. 82b. See also chapter 10 note 190 above.

144 See Ravitzky, History and Faith, 154-204; Wolfson, "God, the Demiurge and the Intellect: On the Usage of the Word Kol in Abraham ibn Ezra," 77-111; Howard Kreisel, "Miracles in Medieval Jewish Philosophy," JQR 75, no. 2 (1984): 99-133; Kreisel, “The Term Kol in Abraham ibn Ezra,” 29-66.

145 See Saverio Campanini, "Guglielmo Raimondo Moncada (alias Flavio Mitridate), traddutore di opere cabbalistiche," in Guglielmo Raimondo Moncada alias Flavio Mitridate. Un ebreo converso siciliano, ed. Mauro Perani (Palermo: Officina di Studi Medievali, 2008), 62.
} 
of the two types of Kabbalah more than any of the other major differences between them.

Unlike the theurgical approach of the main line of Kabbalah that assumes as its main working hypothesis that the divine powers (sefirot) can be affected by human activities, Abulafia is careful not to blur the gap between the natural world, which can indeed be changed, and the higher world of the separate intellects, who cannot under any circumstances be affected by man: "Do not opine that I believe that the separate intellects are under the hand of man, since this is impossible to say or to think at all, but that [I believe that] he changes nature, the world behaves under his hands, as it is confered to man." ${ }^{146}$ It may well be that his denial is a polemic against Rabbi Baruch Togarmi's view of the "supernal world" being given over to human hands. ${ }^{147}$ Magic is therefore conceivable, but not a theurgical impact, as the theosophical Kabbalists allege.

The assumption that there is no change in the divine world is highly apparent in a very rich and seminal passage found in one of Abulafia's epistles that I propose to call "Ha-Seder ha-Mithapekh," a text rather neglected in modern research:

You should know that a person who does not know the order of the ten sefirot, upon which all existence is moving, the supernal, the median, and the low, will never know the providence of the Holy One, blessed be He, on the three. How is this? The ten sefirot of Belimah ${ }^{148}$ will teach us

146 Untitled Treatise, Ms. Firenze, Laurenziana, Plut. II, 48, fol. 83b:

ואל תסבור שאני מאמין שהשכלים הנפרדים תחת יד האדם כי זה לא יתכן לאומרו ולא להעלותו על הלב כלל אמנם כשהוא

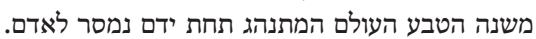

See also Mafteaḥ ha-Ra'ayon, 5: כי לא ימצא שינוי בשכלים הנפרדים כל לאדם, as well as in his "Ševa' Netivot haTorah," 25:

דע באמת שהמדות מתהפכות לקיצים ידועים בלי שנוי ותמורה מפני הנהגת הנבראים. והשנוי הוא לנפעל לא לפועל מצד הכרח ענין הנמצאים.

"You should know in truth that the attributes change at fixed dates, without change and shift, because of the rule of the creatures. But the change is in the causarum and in the cause, because of the necessity of the entities."

See also Sefer ha-Hešeq, 28; compare to the different perception of Abulafia's attitude to theurgy in Wolfson, Abraham Abulafia, 82-83. See also Wolfson, Abraham Abulafia, 175, where he admits that Abulafia has allegorised theurgy and assumes that there is a tension between his different views. Thus, Wolfson implicitly excludes the possibility that Abulafia had a basic conceptual view that negated theurgy in principle. However, Wolfson does not express this view explicitly, as Abulafia does in the passages quoted in this footnote, which Wolfson does not address even though some of them were available in the books by Abulafia with which he was acquainted. This denial of theurgy should be the clue for attempting to understand the meaning of התהפכות המידות ("the inversion of the attributes"), which Wolfson understands theurgically. See Wolfson, Abraham Abulafia, 172-173 and note 213, which is an issue that deserves a separate analysis. See, meanwhile, the passage from Hayyei ha-Nefeš in Appendix E below. Compare also to Lorberbaum's presentation of Maimonides's view in Dazzled by Beauty, 39-40, note 92.

147 See Scholem, The Kabbalah of Sefer ha-Temunah, 235.

148 Cf. Sefer Yeșirah, 1:2-8. The sefirot are identified here with letters that also have numerical valences, as in many other cases in Abulafia's writings. 
the essence of the existence of the Holy One, blessed be He, who is like a fast [writing] scribe ${ }^{149}$ who rotates the letters, though He is not of the species of the sefirot, but all the sefirot are dependent on His will to govern them as He would like, but His will depends upon His wisdom, and His wisdom depends upon His power, and His power depends on Him, but He, blessed be He, does not change and does not shift and is not exchanged, and also His power does not add to Him, and His wisdom is not different from power and nor is His will without His wisdom [...] since He is intellect, intellection, and intelligibilia ${ }^{150}[$ [...]. And there is no doubt that those issues will be shifted in [human] creatures in accordance with the essence of those creatures. And a person who contemplates them and comprehends the[ir] beginnings will think that just as they are exchanged in the creatures, so they will be exchanged in the Creator, blessed be He. And most sages of the world will err on this issue, and it will not be revealed except to the prophets alone that the Holy One, blessed be He, revealed to them by the knowledge of His name, blessed be He, in accordance with the rotations of those divine ${ }^{151}$ systems. ${ }^{152}$

The passage deals with the ten sefirot, conceived as identical to the first ten Hebrew letters, whose different forms of permutations are described in detail immediately after this passage. This means that the sefirot are some form of numbers, as we learn from the fact that their numerical values are assiduously calculated in the following discussions.

However, what is interesting here is not only the Pythagorean theory of numbers as the principles of the universe, which leads to a non-theosophical and non-theurgical understanding of the sefirot, ${ }^{153}$ but the negation of the idea that there is a change on high because the three divine attributes (will, wisdom, and power) are represented as being identical to the divinity, which is described as not changing. If changes are discerned, these changes are actually changes within the creatures (that is, within human beings), with no ontological correspondence on high. A theurgical impact on the divine sphere would, according to this passage, be an

149 Compare to Psalms 45:2.

150 For more on this triad, see Appendix C.

151 The divine systems (ma'arakhot) here stand for various methods of combining letters, described in the epistle immediately after this passage. Abulafia describes letters, especially in his later writings, as divine.

152 Ms. London, British Library, Catalogue Margoliouth 749, fol. 30a:

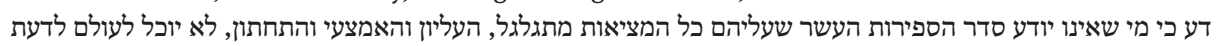

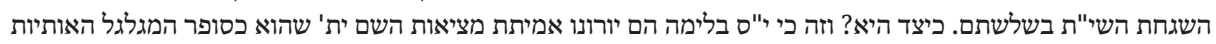

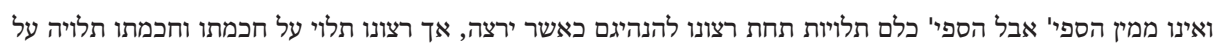

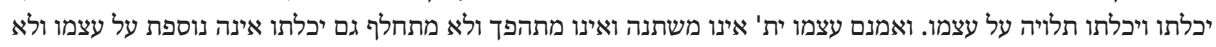

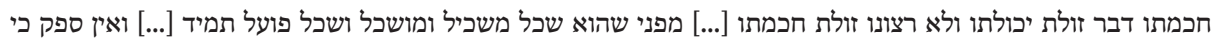

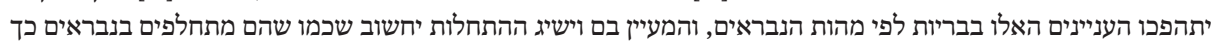

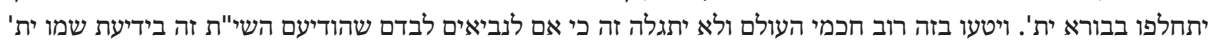
והוא לפי גלגול אלו המערכות האלוהיות. On this text and its relationship to Abulafia, see Idel, "Abraham Abulafia’s Works and Doctrine," 2930, and Idel, "Sefer Yetzirah and Its Commentaries," 512-13.

153 I hope to elaborate on these issues in a separate study. See Idel, Ben, 317-18. 
error, ${ }^{154}$ and the only realm changes are those made by humans when they combine the letters that are conducive to their knowledge of God. Let me point out that in this epistle, Abulafia relies heavily on the theory of letter combinations in the essentially lost Commentary on Sefer Yeșirah by Rabbi Isaac of Beziers, ${ }^{155}$ and he does not mention the performance of the commandments in the context of the changes in humans.

Interestingly enough, this philosophical tradition about the possibility of changing nature had an impact on two authors who were also influenced by Abulafia: Rabbi Moses Narboni and the anonymous mid-fifteenth century author of the treatise Toledot Adam. In the latter treatise, whose author was well-acquainted with Maimonides's discussion of the tablets as natural matters, ${ }^{156}$ there is an interesting claim to the effect that the prophet's miracles are problematic since "nature is the will of God and the will of God, blessed be He, does not change [...] and if the enterprise is attributed to God, blessed be He, in that miracle then it seems that God operated by a change of will, and this is also inappropriate."157 The question of the divine will, which can change and be changed according to Rabbinic sources and still more to the Kabbalistic ones, became quite a problematic topic for the Maimonideans.

This disappearance of the formative role of the divine will is also obvious in the manner in which redemption is described:

The governance is divided between the two ${ }^{158}$ for the ends, and for the [cosmic cycles] šemițin and Jubilees by the sefirot. ${ }^{159}$ And a person who does not know the secret of the ends will

154 See also the interesting discussion in Sitrei Torah, 111. These examples dramatically problematise the theurgical understanding of some aspects of Abulafia's Kabbalah as advocated by Wolfson, Abraham Abulafia, and as discussed in chapter 5 note 165 and chapter 17 note 146 above; see also Pedaya's uncritical acceptance of this interpretation in her "The Sixth Millennium," 67-68. She even claims that this Kabbalist's historical activity belongs to the category of theurgy! This is part of what I call the mirror vortex. See also Appendix E.

155 See Idel, "Sefer Yetzirah and Its Commentaries," 485, 504-27. The acquaintance of this Kabbalist, whom I proposed to identify as Rabbi Isaac ben Jacob ha-Kohen, with Ashkenazi material is part of a broader phenomenological affinity. See also the many discussions on the affinities of the discussions between the Spanish Kabbalists on divine names, especially in the second part of the thirteenth century in Castile, and the earlier Ashkenazi sources in Asi Farber-Ginat, "The Concept of the Merkabah in the Thirteenth-Century Jewish Esotericism-Sod Ha-Egoz and Its Development” [Hebrew] (PhD diss., Hebrew University, 1986); Abrams, “'The Book of Illumination' of Rabbi Jacob ben Jacob HaKohen," 57, 61, 85, 111, and 247; Ben-Shalom, The Jews of Provence and Languedoc, 574-75.

156 See the quote from Guide 1:66, Ms. Oxford, Bodleian 836, fol. 166ab.

157 Ms. Oxford, Bodleian 836, fol.167b: 'שהטבע רצון אלהי ורצון הש"י לא ישתנה [...] ואם ייוחס המפעל לשם ית" באות ההוא א"כ נראה שהש"י יפעל בשינוי רצון, גם זה מגונה. See also fols. 163a and 165b.

158 Namely, between the sun and the moon.

159 One might be tempted to see here a Kabbalistic theory of the connection between the sefirot and cosmic cycles, as found in Nahmanides's school. See Haviva Pedaya, Nahmanides: Cyclical Time and Holy Text [Hebrew] (Tel Aviv: Am Oved, 2003), 274-93, and Idel, "The Jubilee in Jewish Mysticism." However, it seems doubtful whether here the sefirot are conceived as referring to divine powers presiding over cosmic cycles (basically an astronomical theory predating the Kabbalists), but they point to measures of time, as we shall see immediately below. 
never know the secret of the renewal of the world ${ }^{160}$ in truth [...]. Behold, the renewal of the world will necessarily be in accordance with the measures, ${ }^{161}$ and the measures will, indubitably, be in accordance with the [divine] names. And the names will be revealed and concealed, in accordance with the letters. And from this renewal, the ascent of a nation or nations will take place, as well as the decline of another nation or nations. ${ }^{162}$

Abulafia subscribed to a cyclical type of astral undulatory historiosophy (that is, a form of eternal return), which is also connected to the ascent and decline of the nations, including the Jewish one. These shifts in the statuses of nations are generally described as related to revelations of secrets found within letters, divine names, and attributes or measures (middot). ${ }^{163}$ In the broader context of this passage, which deals with the secret of impregnation, there is a relationship between the divine names and the formulas that inform the renewal or decline of nations. ${ }^{164}$

What is especially important for our discussion here is the fact that the divine will is not described as intervening in this process. Indeed, after the above passage, Abulafia mentions the governance of the special nation that will assimilate all the other languages and scripts; however, even in this case, this is not part of a final, definitive redemption, but is rather merely an example of the process of renewal, which follows a strictly astral rhythm related to the celestially combined cycles of the sun and moon. This, let me emphasise, is a natural process that does not include divine intentionality or intervention; it is neither a change within the divine realm nor a change in the configuration of the divine powers, as in theosophical-theurgical Kabbalah. ${ }^{165}$

\section{On Nature and the Divine Choice}

Let me engage the question of the relationship between nature and the divine choice in more general terms, in addition to our earlier discussion of the Hebrew language being natural. There are several instances in Abulafia's writings where it is nature,

160 Hidduš ha-'olam. This term should be understood in this context, as in some other places in Abulafia's writings, as pointing not to creatio ex nihilo, but to periodical renewal, as is the case with the moon: hidduš levanah.

161 In Hebrew, מדות is similar to sefirot, to be understood as numbers. My reading is dependent on the parallel found two passages beforehand, where the verbs נמדדות and ונספרות are used in the similar context of the teqqufot. See Oșar 'Eden Ganuz, 2:1, 204.

162 Oșar 'Eden Ganuz, 2:1, 207:

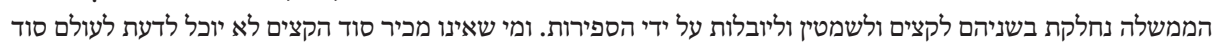

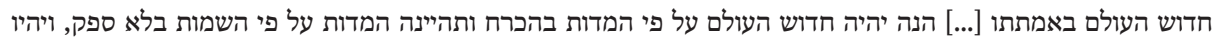
השמות נגלים ונעלמים על פי האותיות ויתחדש מחדושו זה עלית אומה אות או אומות וירידת אחרת אות אות אחרות. 163 Oșar 'Eden Ganuz, 1:2, 94, 103.

164 See Idel, Messianic Mystics, 80-81. Abulafia's interpretation of the secrets of impregnation differs from that of other Kabbalists and will be discussed in a separate study.

165 See Idel, Messianic Mystics, 79-82. 
not the divine will, that is conceived as determining the course of events. ${ }^{166}$ Indeed, in a seminal passage from Oșar 'Eden Ganuz, which is a parallel discussion to paragraph [d] from Or ha-Śekhel translated in Appendix A below, the term Behirah ("choice") is conceived as a homonym; that is, it is conceived as having more than one meaning. I propose to compare this passage, which I shall translate in this chapter, to the text from Or ha-Śekhel that will be under scrutiny below:

One can say about each and every thing of them that He chose for it to be what it is, and how this choice is better than any other and even in natural particular matters, $a$ fortiori in the universal ones. We may say that nature chose that this body would be more sublime than another body, and nicer and stronger, even in the case of two individuals of the same species. And it was also said that of two species, one is naturally better than the other, and this is called by the name Behirah as an equivocal name. ${ }^{167}$

I propose to see here a certain gradation in which the first represents the more traditional approach while the two later approaches are much closer to the views of Maimonides and Abulafia. In the first case, God chooses; in the second and third, nature does so. What counts in this context is the assumption that what is better is a matter of nature.

On the connection between nature and choice, already addressed in one of Abulafia's earliest books, Abulafia states that "in our language, this nature is called 'choice,' as it is said: seven firmaments were created by the Holy One, blessed be He in His world, and out of them all, He chose to put His Seat of Glory for His kingdom in 'Aravot."168

As we have seen above, like Maimonides, in his writings Abulafia uses homonyms or equivocal terms, such as words occurring in the sacred scriptures, in order to hide an esoteric meaning that is conceived as problematic for simple-minded readers of Jewish tradition. ${ }^{169}$

166 See Or ha-Śekhel, 40: שהיצירה האנושית הטבעית גזרה and also Or ha-Śekhel, 121: גזר טבע השכל האלה משלה שישפיע שכל על נפש הנביא, שהיא הכח הדברי tellect will be emanated upon the soul of the prophet, that is the speaking [namely, the intellectual] faculty." See also Or ha-Śekhel, 45. For a similar position, see the view of the anonymous author of Sefer Toledot Adam, Ms. Oxford, Bodleian 836, fols. 165b, 167b, where the gematria Elohim $=$ Teva occurs together with the assumption that nature is tantamount to the divine will. Cf. Idel, "Deus sive Natura," 97-98.

167 Oṣar 'Eden Ganuz, 1:10, 185-186:

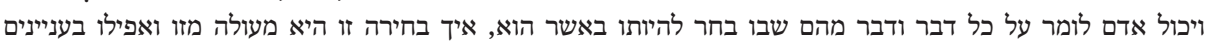

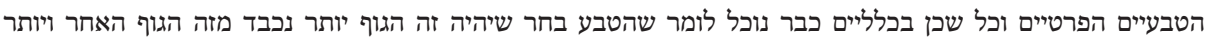

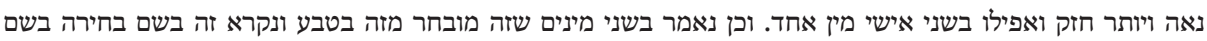
משותף.

168 Mafteaḥ ha-Ra'ayon, 43-44:

בלשונינו נקרא זה הטבע בחירה, כאמרם שבעה [רקיעים] ברא הקב"ה בעולמו ומכולם לא בחר להיות כסא כבוד למלכותו אלא ערבות.

169 See Abulafia, Hayyei ha-Nefeš, 11, where he regards the "secrets of the equivocality of names" as the clue for the Guide and for other unspecified writings. On homonyms in the Maimonideans, see 
We learn about the existence of a "great secret" that is considered to be related to Behirah from one of Abulafia's early books, Sefer ha-Melammed, where he mentions "absolute nature" (in Hebrew, țeva' gamur), quite a rare phrase in the thirteenth century, ${ }^{170}$ which is of the utmost importance in the context of qualifying the concept of divine choice:

Justice and law [belong] to God indubitably, since they are attributed to him by a great affinity, by absolute nature, according to the directives of existence. However, about the secret of choice, it has been said that "He chose the [firmament of] 'Aravot," "171 as you can understand from the blessing of the Torah, "You have chosen us from all the nations," and as it was said" "and the Lord chose you," as well as ${ }^{173}$ "and He chose his seed after him," and we also say that ${ }^{174}$ "He chooses the Torah and Moses His servant, and the prophets of truth and justice." You should understand this very well, and from this, you should understand the secret of "you should choose life" [Deuteronomy 30:19]. ${ }^{175}$

This aura of secrecy around the theme of divine choice is extremely important for an understanding of Abulafia's esotericism: what was conceived as an obvious and undisputed topic in the Jewish tradition here becomes a problem that must be understood esoterically. The assumption that one should read all the pertinent verses and blessings as containing a secret is certainly indicative of an interpretation that does not fit the ordinary concepts of choice.

The direction of the interpretation is found in the above passage when the phrase "absolute nature" is mentioned; its possible contribution to our understanding of Abulafia may be elicited from the following statement found in the context of the pearl parable, where Abulafia writes: “And nature also determines that God will choose a specific thing from all the details of matters, as He chose 'Aravot from all the spheres." 176 The parallelism between the last two quotes is quite evident and leads to the conclusion that it is nature that determines divine actions. This is a secret that Abulafia preferred to keep, resorting in some cases to the more traditional

Robinson, "We Drink Only from the Master's Water," 40-47. See also the important discussion in Or ha-Śekhel, 29, where the choice of the human species is related to the existence of the intellect in this species.

170 The other occurrence of this phrase is found in Abulafia's Hayyei ha-Nefeš, 32, and his student's Ša'arei Ședeq.

171 On this choice, see Appendix A. Compare to Maimonides's Guide 1:70.

172 Deuteronomy 14:2.

173 Deuteronomy 4:37.

174 According to the blessing after the reading of the portion from the prophets.

175 Ed. Gross (Jerusalem: 2002), 31:

וצדק ומשפט הם לאל בלא ספק כי הם מיוחסים אליו בקרבה גדולה בטבע גמור לפי הנהגת המציאות. ואמנם סוד הבחירה

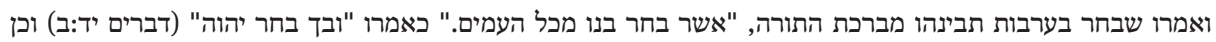

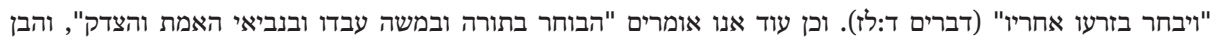
זה מאד וממנו תבין סוד "ובחרת בחיים" (דברים וכוד (דברים ל:יט).

176 For the full Hebrew text and an English translation, see Appendix A. On divine volition and choice in Maimonides, see Goodman, "Maimonidean Naturalism," 167-74. 
vision of the election, formulated within the framework of that which defines the nation genetically. ${ }^{177}$

According to some concepts which were expressed in medieval Hebrew writing by a phrase that means "according to the recipient," the result of the divine influx depends entirely on the recipient's preparation. There are other instances in Abulafia's writings where the specific nature of a certain entity determines the result of the interaction between the unchanging divine action and the nature of the recipient, as is the case with the nature of man which "determined" that God allows the power of speech. ${ }^{178}$ In short, while Maimonides sees in the divine wisdom the quality that determines the divine acts, Abulafia, following the Great Eagle by using the same phrase, assumes that it is the very structure of existence that is to be understood as determining the acts related to it and attributed to God. Especially interesting in this context is a statement in Hayyei ha- 'Olam ha-Ba': "The essence of the Israelite faith is that the Holy One, blessed be He, created everything and brought it out of nothing, when knowledge of His wisdom, blessed be He, has determined His preeternal, permanent will, ${ }^{179}$ which will not change in any case or by any form of change, and will not multiply by any multiplicity."180 The inexchangeable will, pre-eternal and informed by divine wisdom, is indeed described as creating the world ex nihilo, but it is obvious that there is a tension, in fact a contradiction, between the various parts of this short passage.

Let me compare this view to what Abulafia wrote in the same year in his Sitrei Torah, where he distinguishes between the Greek nomenclature, based as it is on terms "pointing to the pre-eternity of deeds that are found within the permanent wisdom, without a volitional intention" on the one hand, and the Jewish terminology on the other. The Greek one is indubitably the inverse of what he calls "our opinion" which is expressed by terms conveying "innovation of the created deeds, by intention and will." ${ }^{181}$ It seems that what the Kabbalist ascribes to the Greeks here is

177 See Mafteah ha-Sefirot, 68-69. Let me point out that Abulafia did not accept it on the esoteric level, as he did not accept Judah ha-Levi's view or the Muslim view of the innate Muslim faculty ( $f$ trah). For the assumption of the possible influence of ha-Levi on Abulafia, see Wolfson, "Kenotic Overflow and Temporal Transcendence," 141, note 21. For the problem posed by the biblical concept of nation, see Steven Grosby, "The Biblical 'Nation' as a Problem for Philosophy," Hebraic Political Studies 1 (2005): 7-23. See also Haim Hillel Ben-Sasson, "Jewish Reflections on Nationhood in the Twelfth Century" [Hebrew], Peraqim 2 (1969-74): 145-218.

178 Mafteah ha-Sefirot, 3. See also Imrei Šefer, 202: "The wise always chooses the best."

179 The phrase reșono ha-qadum occurs already in another context in the translation of the Guide 1:10, Pines, 1:36. See also Goodman, "Maimonidean Naturalism," 175-87.

180 Hayyei ha-'Olam ha-Ba', 48:

אמיתות האמונה הישראלית היא, שהשי"ת ב"ה ברא הכל והוציאו מאין ליש, כשגזרה ידיעת חכמתו ית"ש ברצונו הקדום

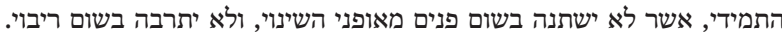

The term rașon qadum, "pre-eternal will," is also found in the anonymous Sefer Or ha-Menorah, Ms. Jerusalem, NUL 1303, fols. 28b and 43a, which is from Abulafia's school. See also Oșar 'Eden Ganuz, 1:2, 83: 'רצון השם הקדמון ית.

181 Sitrei Torah, 36: 
quite similar to what he defines as the essence of the Jewish faith in the other book. The contradiction is, in my opinion, evident and I would say that what he hinted at in Hayyei ha-'Olam ha-Ba' represents his secret position, which he vehemently negates in Sitrei Torah. In other words, I do not see here a case of conceptual fluidity-namely, of a change of mind as part of a certain type of intellectual evolution-but rather a case of esoteric discourse that includes two diametrically opposed positions, and this contradiction between the two positions expressed in books written in the very same year is premeditated, part of his esoteric style.

Perhaps the distinction between the Greeks, who are portrayed as holding an incorrect position, and Abulafia's traditional position, which is envisioned as correct, has something to do with the intended audience of Sitrei Torah: four young people who eventually deserted him, as he angrily indicates. ${ }^{182}$ In any case, the above distinction is part of a wider discussion dealing with the Rabbinic statement ${ }^{183}$ that recommends preventing young people from studying logic. ${ }^{184}$ However, despite the fact that Abulafia takes, in a reserved manner, the part of the traditional camp in this debate, criticising the view of Rabbi Samuel ibn Tibbon, ${ }^{185}$ he himself studied logic in his youth and confessed to doing so without any reservation some years after Sitrei Torah both in texts that I discussed above and in others I will mention below. His view is that the Rabbis intended their interdiction only for immature young people and not for mature ones, a view that is consonant with that of Rabbi Jacob Anatoli. ${ }^{186}$

In the same book, Abulafia expressly says, in the context of studying logic, that "reality shows the philosophers the essence of matters in an easy manner," although Kabbalah, based on meditation on letters, does so "in an even easier manner." 187 The mention of this easiness may have something to do with the concept of hads (a form of intuition), which is a concept found in Muslim philosophy and in Maimonides. ${ }^{188}$ This means that his approach does not invalidate philosophy, but offers an easier

וההבדל אשר בינינו לבינם שאנחנו קראנום בשמות מורים חידוש מעשים נבראים בכוונה ורצון, והם קראום בשמות מורים קדמות מעשים נמצאים בחכמה תמידית בלתי כוונה רצונית. ודעתם הפך מדעתנו בלא ספקות.

182 See p. 74 above.

183 BT, Berakhot, fol. 28b. The possible meanings of this Rabbinic statement and its medieval interpretations have been debated by scholars. See Mordekhai Breuer, "Keep Your Children from Higayon" [Hebrew], in Mikhtam le-David: Sefer Zikaron le-rav David Ochs, eds. Yitzhak D. Gilat and Eliezer Stern (Ramat-Gan: Bar-Ilan University Press, 1978): 242-61, and Frank Talmage, "Keep Your Sons from Scripture: The Bible in Medieval Jewish Scholarship and Spirituality," in Understanding Scripture: Explorations of Jewish and Christian Traditions of Interpretation, eds. Clemens Thoma and Michael Wyschogrod (New York: Paulist Press, 1987): 81-101.

184 Idel, “On the History of the Interdiction," 15-20.

185 See Sitrei Torah, 35-36.

186 See Idel, "On the History of the Interdiction," 17-18, and Idel, "Sefer Yetzirah and Its Commentaries,” 534-35.

187 See Sitrei Torah, 160. See also my Absorbing Perfections, 90-91.

188 See Amirah Eran, "The Diffusion of the Hads Theory of Avicenna from Maimonides to Rabbi Nahman of Bratzlav" [Hebrew], in Maimonides and Mysticism, 71-76, and my "On the Meanings of the Term “Kabbalah,”' 58-59. 
path to understanding, by means of what he regarded as a higher type of logic. This rather positive attitude towards the findings of the philosophers is obvious elsewhere where he describes them as "the sages of the nations who are perfect in those issues" in the context of the adherence to the Agent Intellect, ${ }^{189}$ perhaps also a reference to the thought of Avicenna or Averroes.

Immediately afterwards, Abulafia confesses that he "agreed with them in all," again related to the comprehension of the Intellect. ${ }^{190}$ Abulafia indeed has a more complex understanding of Kabbalah, since he understands what he calls "the first Kabbalah" to be an approach based on accepting contents by means of traditions that are not demonstratively examined-like the so-called "truthful tradition" ( $h a$ haggadah ha-ne'emanah) in Rabbi Sa'adya Gaon ${ }^{191}$-and thus it is conceived as being replete with imagination, while his own Kabbalah, after it is purified of imaginary contexts, is an examined and intellectual one. ${ }^{192}$

I propose to understand this type of problem related to the nature of the divine will as part of radical Maimonideanism as it assumes an approach close to the medieval theory known as potentia dei ordinata. ${ }^{193}$ However, it seems that Abulafia's approach was more explicit and extreme than the views of the other Maimonideans. Such an interpretation of the term Behirah as a nature that impedes the divine choice cuts short the widespread assumption in traditional forms of Judaism that the Jews are, ethnically speaking, the chosen people elected by the free will of God or that they are the portents of the so-called "divine issue." It allows, however, the assumption that they may be superior to other nations by dint of some natural qualities such as, in our context, respecting the correct pronunciation of the twenty-two natural, innate consonants, as we have seen above.

This is a cardinal point that should be taken into consideration when portraying the special characteristic of Abulafia's thought: the dialogue with his specific philosophical backgrounds, as described above, was paramount for his thought long after he turned into a Kabbalist; he maintained a more universalistic approach in his writings, though this dimension was an integral part of his esoteric narrative. In one case, in his last known book, he claims that a certain topic may be revealed solely to "the sages of The Guide of the Perplexed" because it may create what he calls "a great perplexity."194 This means that he refers to at least some of his followers

189 Sefer Mafteah ha-Šemot, 25-26.

190 Sefer Mafteah ha-Šemot, 26.

191 Wolfson, "The Double Faith Theory in Saadia, Averroes and St. Thomas."

192 See Hayyei ha-Nefeš, 83; Commentary on Sefer Yeșirah, 8-9; and, in particular, the phrase קבלה מושכלת, "the Kabbalah that is understood by the intellect," occurring in "Ševa' Netivot ha-Torah," 9. This description is like his other two that are better known. The Kabbalah of Names and the prophetic Kabbalah were not used by Kabbalists who did not belong to his school in the thirteenth century. 193 See Ravitzky, Maimonidean Essays, 157-80. See also Halbertal, Concealment and Revelation, 139. 194 See Imrei Šefer, 8: כי אין ראוי לגלות זה כי אם לחכמי מורה הנבוכים כי היא מבוכה גדולה. 
in such a manner; namely, as qualified recipients of the secrets he would like to impart.

For Abulafia, let me emphasise, it is the philosophical concepts and their impact on traditional themes that constitute the content of his esotericism, not the theosophical ones, as the former alone are capable of accounting for internal human improvements. ${ }^{195}$ In my opinion, Abulafia recurrently uses the imagery of "nature" in order to undermine the divine free choice and consequently to understand the superiority of the Jews only when he describes it in what he considers to be natural terms.

It should be pointed out that Abulafia resorts to the term "nature" hundreds of times in his writings, much more than any other Kabbalist with whom I am acquainted, and perhaps more than all the theosophical-theurgical Kabbalists in the thirteenth century altogether. This emphasis is also evident in the case of Rabbi Nathan ben Sa'adyah's shorter treatise $\breve{S}$ 'a arei Ședeq, in which he acknowledges the philosophical source of the importance of teva', and describes, in a manner reminiscent of Abulafia, the external nature as a parable for the inner nature. ${ }^{196}$ In fact, according to the testimony of Rabbi Nathan, he asked his teacher Abulafia:

Why did you write books [based] on the ways of nature, together with teaching the [divine] names? He told me: for you and those like you among those interested in philosophy, in order to draw your human intellect by way of nature, perhaps this drawing will be the reason for bringing them to the knowledge of the Name. ${ }^{197}$

Philosophical explanations are understood here as tantamount to natural interpretations, in a manner reminiscent of the critique of Rabbi Joseph Ashkenazi, whom we quoted at the beginning of this study. Here, this manner of composition is presented as a strategy for persuading the young elite who are already acquainted with the study of the Guide and natural sciences, as Rabbi Nathan himself already was, to enter into Abulafia's type of Kabbalah. ${ }^{198}$

On the other hand, as we have seen above in some instances, Abulafia uses the שינוי הטבע phrinnui ha-țeva') several times; this phrase refers to a change of na-

195 For more on these issues, see my Primeval Evil: Totality, Perfection and Perfectibility, 363-70. 196 For example, see some of the occurrences in Le Porte della Giustizia: 469, 471, 473, 475, 477-78, 479, 480, and 481. See also the gematria moah $v a-l e v=t e v a^{\prime}=86$ that occurs in Abulafia's writings, such as Mafteah ha-Šemot, 33.

197 Le Porte della Giustizia, 478:

וכבודך מפני מה מחבר ספרים בדרכי הטבעים משותפים בהוראת השמות, אמר לי בעבורך והדומי' לך מן המתפלספים

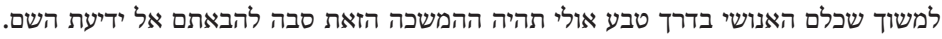
This characterisation also fits what Rabbi Solomon ibn Adret had to say about Abulafia's writings in his famous responsum 1, no. 548 .

198 See his confession as to the things he studied before meeting a Kabbalist (Abulafia): Le Porte della Giustizia, 477. 
ture, especially through the activities of the prophets. ${ }^{199}$ This is the reason why one may ask: what is the meaning of obliterating the divine choice and perhaps also the divine will to change nature, while nature, or at least parts of it, may be changed by divine names when used by some people? At least in one case, Abulafia claims that it is the plain sense that is intended for the multitude of Israel, dealing as it does with changes in parts of nature. ${ }^{200}$

According to another passage whose meaning is far from transparent, Abulafia offers an interiorised understanding of miracles:

\begin{abstract}
And what comes from the miracles, in accordance with what has been intelligised from letters and words that are understood by the intellect after a great amount of study. And the Kabbalistic issues are the wonders and miracles which are engraved in every Kabbalist's heart, and when they move from potentia to actu, in accordance with the aforementioned manner, by means of the breathings that are known from tradition, the matters are accepted willingly and immediately for anyone who comprehends in accordance with the power of the recitations, which amounts to the complete comprehension. ${ }^{201}$
\end{abstract}

Abulafia resorts to the pun otot/otiyyot ("wonders"/“letters") because it is by means of letters (which are essentially sounds) that miracles (moftim, "changes of nature") are performed. Abulafia is here describing the mystical technique that he invented based on reciting letters and breathing. ${ }^{202}$ By following the instructions found in this technique, a person is capable, so he argues, of changing his inner nature, as we also learn from other instances in his writings. ${ }^{203}$ Presumably, Abulafia is speaking here about changes of what his student Rabbi Nathan ben Sa'adyah calls "the inner nature." ${ }^{204}$ The matters may stand for questions a person has and are answered as part of a revelation related to the performance of the technique.

199 See Or ha-Śekhel, 27-28, 120; Hayyei ha-'Olam ha-Ba', 195-96; as well as the anonymous text found in Ms. Moscow, Güzburg 737, fol. 83a, which will be printed in a separate study. See also Idel, Studies in Ecstatic Kabbalah, 63-71; Idel, "Incantations, Lists, and 'Gates of Sermons," 499501; and Ravitzky, History and Faith, 154-204. In an interesting reference to Abulafia, informed by the above-mentioned passage from Hayyei ha-'Olam ha-Ba', Rabbi Johanan Alemanno mentions the possibility of performing miracles. See Hešeq Shlomo, Ms. Oxford, Bodleian 1535, fol. 147a. Alemanno was well-acquainted with this book of Abulafia's. Cf. his Collectanea, Ms. Oxford, Bodleian 2234, fols. 95a-96b, 148a-149a; he was also very fond of Narboni's writings. Narboni was one of the channels through which some of those ideas penetrated into the Italian Renaissance.

200 Mafteah ha-Šemot, 49.

201 Mafteaḥ ha-Šemot, 86:

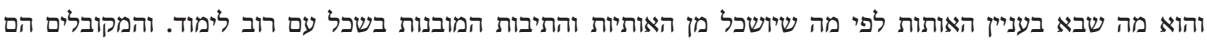

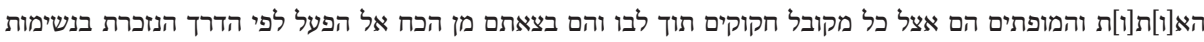
המקובלות עניינים מתקבלים ברצון מיד למשיג על פי כי כח ההזכרות המודיעות ההשגה כולה כולה.

202 See Idel, The Mystical Experience, 13-52.

203 See Abulafia, Geț ha-Šemot, 40: ועל טבע האדם החיצון והפנימי Compare also Geț ha-Šemot, 1. See also Oșar 'Eden Ganuz, 3:10, 364, discussed in chapter 21 note 291 below.

204 Le Porte della Giustizia, 463. 
This quandary may also be explained in a somewhat different manner: it is only man who has a free will that allows him to be preoccupied with material issues that are considered to be lower than spiritual ones. In this context, it is important to highlight the almost total absence in Abulafia's writings of Maimonides's claim that the biblical figure Baruch ben Neriah was prevented from prophesising by the divine will. ${ }^{205}$ His view is that "it is impossible that a natural matter will change from the aspect of nature, and if something changes quite rarely and by dint of a volitional divine wonder, this will be by means of a prophet in order to validate his prophecy, [changing] one of the parts of natural existence." ${ }^{206}$ Again, this is quite a weird formulation: the change in nature, which is supposed to depend on the divine will, is immediately qualified as being caused by the prophet because of his need to validate his mission.

In a way, it seems that Abulafia radicalised Maimonides's more moderate naturalistic approach to religion in his exoteric views by resorting to the term "absolute nature” in contradistinction to Nahmanides's famous statement about Maimonides in a well-known sermon: "We are amazed by Maimonides, blessed be his memory, because he diminishes miracles and enhances nature, and he says that miracles only persist for a while." 207 This is just one more example, if one were needed, of

205 See Imrei Šefer, 40, where this view is presented as a "wondrous secret":

ואם לא נגלה לו זה הסוד המופלא ידאג כברוך בן נריה על בקשו הנבואה כשלא ישיגנה כאומרו יגעתי באנחתי ומנוחה לא

מצאתי.

This statement, however, does not imply that God prevented Baruch from prophesying, but the contrary. Compare to the Guide, 2:32, Pines, 2:362.

206 Or ha-Śekhel, 27:

והעניין הטבעי אי אפשר שישתנה מצד הטבע, ואם ישתנה בו דבר לעתים רחוקות, ועל ידי הפלא הרצוני האלהי יהיה על ידי נביא להצדיק נבואתו בחלק מחלקי המשיאות מצדיאות הטבעי.

See also Or ha-Śekhel, 27-28, and 66, where he does not mention Neriah, but speaks about the possibility that the divine will may prevent some form of cognition. However, in Imrei Šefer, he speaks about a great secret related to the possibility of prevention. See 37:

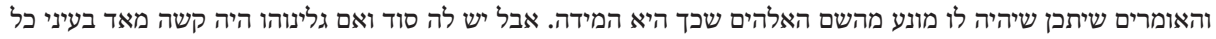

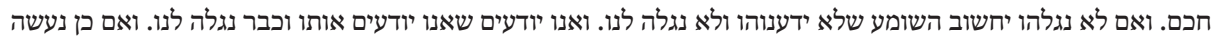

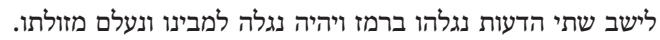

207 See his sermon "The Torah of God is Perfect," in Kitvei ha-Ramban, vol. 1, ed. Chaim D. Chavel (Jerusalem, Mosad ha-Rav Kuk, 1963), 154:

על כן נתמה מן הרמב"ם ז"ל שהוא מגרע הנסים ומגביר הטבע, ואומר שאין הנסים עומדים אלא לפי שעה. For a somewhat similar view, see Kitvei ha-Ramban, 1:158, where he refers to "Rabbi Abraham," probably ibn Ezra:

אולי שמע דעת אפלטון שהוא סובר שהעולם בהויתו מחודש אלא שהטבע קדמון שקשה עליו דבר האפיסה. See also Idel, “Abulafia's Secrets of the Guide," 313. See also Nahmanides's expression in his discussion of Genesis 2:17 in his Commentary on the Pentateuch: אנשי הטבע ("the people of nature"), which refers to some form of naturalist view. For Nahmanides's complex theory of miracles, see the analysis by Moshe Halbertal, By Way of Truth: Nahmanides and the Creation of a Tradition [Hebrew] (Jerusalem: Shalom Hartman Institute, 2006), 149-80, especially 178-79. For Nahmanides's voluntaristic theosophy, see Moshe Idel, "On the Concept of Șimșum in Kabbalah and Its Research" [Hebrew], in Lurianic Kabbalah, eds. Rachel Elior and Yehuda Liebes (Jerusalem: Hebrew University, 1992): 61-62; 
the stark divergences between Abulafia's Kabbalah and the theosophical-theurgical one represented by Nahmanides and his followers in Barcelona. It may well be that Abulafia was reacting to Nahmanides's critique of Maimonides in his famous sermon. In any case, in an interesting discussion by Rabbi Joseph Ashkenazi, a Kabbalist we mentioned above, there is a critique of the assumption that the natures of things are permanent such that God cannot change them. ${ }^{208}$

It should be mentioned that in addition to Maimonidean naturalism, there is also another type of naturalism which can be called hermetic; this assumes the possibility of drawing down the overflow from above as part of the experience. In my opinion, this hermetic trend is starkly different from Maimonides's thought, as he was a person who fought a fierce war against magical Hermeticism (which he referred to as Sabianism); it is found in only some of Abulafia's books, ${ }^{209}$ which is an issue on which I hope to elaborate in another study. ${ }^{210}$ This propensity towards causing the descent of the supernal spiritualties is also found in Rabbi Moses Narboni's writings.

\section{The Nature of the Son in the Pearl Parable}

The scholars dealing with the pearl parable interpreted the son as an allegory for the nation mentioned in paragraphs [a] and [c]; namely, the historical people of Israel. This is indubitably true, and means that the Torah in its absolutely intellectual meaning was not delivered to the Jewish nation in the past and is certainly not found in its possession in the present, though they may have some form of priority for receiving it in the future. This is indeed a radical statement, which has many ramifications for a proper understanding of Abulafia's approach to religion in general and to Judaism in particular, as well as for the general history of philosophical religions. Such a reading would constitute an understanding according to the second type of narrative; namely, the historical explanation of the plain sense of the parable. There is nothing esoteric here, and nothing especially spiritual either, but rather a particularist understanding of religion that gravitates around a nation composed of genetic Jews.

However, in my opinion, this understanding, though correct, is not the final message that Abulafia wanted to transmit through his resort to this parable. Such a national-historical reading takes Abulafia's intention solely to a concrete, plain sense,

Pedaya, Nahmanides: Cyclical Time and Holy Text, 274-93; and again in Nahmanides's Commentary on the Pentateuch, concerning Genesis 2:17.

208 Commentary on Genesis Rabbah, 102.

209 See the Abulafian sources translated and analysed in Idel, Enchanted Chains, 94-95.

210 See, meanwhile, Moshe Idel, "Hermeticism and Kabbalah," in Hermetism from Late Antiquity to Humanism, eds. Paolo Lucentini, Ilaria Parri, and Vittoria Perrone Compagni (Brepols: Turnhout, 2004), 389-408. 
as if what was most important for him religiously is what historically happened to a large group of people, genetically belonging to a certain collective category, who were considered to be the sons of God, or the collective son of God. Such an assumption reduces Abulafia's thought to merely a more complex version of the biblical or Rabbinic understanding of Judaism as a corporate personality. In one of his most outspoken confessions, as he discusses the Tower of Babel episode, Abulafia claims that the biblical stories are predominantly intended for the multitude and have only a little interest for the special individual, whom at other points he calls "the distinguished person." 211

However, following Maimonides's Neo-Aristotelianism, Abulafia shifted the importance of the resemblance between father and son from the original corporeal isomorphism, which is the thrust of the discussions in the biblical and Rabbinic traditions regarding the image mentioned in Genesis 1:27, to a spiritual resemblance or a contiguity between the supernal world conceived as an intellectual realm and a perfect man when he actualises his passive intellect. ${ }^{212}$ Unlike earlier forms of morphonominalism-namely, the assumption that a son resembles his father in a physical manner because they share a common shape and also because he bears his father's name ${ }^{213}$-Abulafia was interested in what I propose to call a nous nominalism; namely, the assumption that the true Israel and the divine sphere share not only a common name, but also a common nature, the intellectual one, which means that we have here an intellectual or spiritualised understanding of the name Israel, as we saw in chapter 15 above. According to Abulafia's statement, the secret of the son is the most important secret of the first part of his interpretation of the secrets in the Guide. ${ }^{214}$ Indeed, in his other commentary on the alleged secrets of Maimonides's Guide of the Perplexed, Sitrei Torah, he deals with three different meanings of the term "son." This distinction deserves a more detailed discussion.

For our purpose here, it suffices to say that Abulafia assumes that the Hebrew term Ben is one of the thirty-six secrets hidden in The Guide of the Perplexed that he claims to have understood. Abulafia distinguishes between three different categories of sons in the Hebrew Bible: the ethnic one, the metaphorical-intellectual one, and all the others related to linguistic resorts to the term Ben without any genealog-

211 Or ha-Śekhel, 39. Compare also to his Commentary on Sefer ha-Meliș, Ms. Roma, Angelica 38, fol. 9a, printed in Mașref ha-Śekhel, 8, and his introduction to Mafteah ha-Hokhmot, 6.

212 Idel, Ben, 287. See also Idel, “Abraham Abulafia: A Kabbalist 'Son of God,"” 70-71. Strangely enough, in his book printed in 2012, Sagerman does not seem to know about my lengthy chapter in English on Abulafia and the son of God, which was printed in 2008. This is the reason why his treatment of the theme of the son, in a book dealing with Abulafia's attraction to Christianity, is quite scant, as he is not aware of the strong impact of the Jewish-Christian tradition on one of Abulafia's Ashkenazi sources (i.e., Rabbi Nehemiah ben Solomon, the prophet of Erfurt).

213 See my Ben, 18-22.

214 Hayyei ha-Nefeš, 10. 
ical overtone. ${ }^{215}$ He claims that all the occurrences of the term Ben in The Guide of the Perplexed should be understood as pointing to some form of allegorical meaning, as the phrase "the sons of the prophets" does not refer to the biological relationship between father and son, but to someone who is the disciple of another person. Also, the occurrence of the expression "The Name of Four Letters" (Šem ben Arba' Otiyyot)-namely, the Tetragrammaton-should be understood in a metaphorical manner. He then claims that any causatum, or overflow, is designated as a son, like in the biblical expression Benei ha-Elohim in Genesis 6 which refers to some category of angels.

After establishing the metaphorical nature of the Maimonidean discussions, Abulafia returns to the Bible and asserts that one should not apply this principle of metaphorical reading to all the occurrences of the term Ben because this would generate a form of heresy. On the other hand, however, he claims that one should not assume that all the occurrences of the term Ben in the Bible are dealing with biological sons, since the intellect understands that they are not eternal. In short, we have here an application of Maimonides's exegetical method of homonymy, about which we shall have more to say in this chapter. ${ }^{216}$

Especially important for our discussion is the metaphorical reading he proposes of the biblical phrase "My firstborn Israel," which should be interpreted against its plain sense and read metaphorically. This means that according to an esoteric reading of the Hebrew Bible, it is not a person that is described here, but solely the intellect when it is actualised, as in the case of Seth, who was described as being born in the image and likeness of God.

Abulafia dislocates the national type of sonship as a conclusive definition of Judaism and supplements it with an intellectual one that he conceives as more sublime, which means that he interprets one of the most cherished national values, national sonship, as pointing to an intellectual relationship between God as intellect and a human intellect that is derived from the divine one. By doing so, he highlights another value that is more important than national or genetic belonging. Rather than centring the national collective, as in traditional Judaism, Abulafia prioritises the individual's intellect. In other words, his contribution to the discussions of the concept of sonship in Judaism should be seen in his conspicuous and explicit addition of the register of noetic interpretation as being, in the way I understand him, more important.

Who are these intellectual sons? According to another commentary on the secrets of the Guide, they are the prophets. Abulafia draws this conclusion by resorting to exegetical techniques characteristic of his Kabbalah based on the permutations of the consonants of the word mitnabe'im (which means "they prophesy"), which gen-

215 Sitrei Torah, 22-26, Ms. Munich, 341, fol. 160b. I addressed the content of this passage briefly in Studies in Ecstatic Kabbalah, 54.

216 For the earlier Greek and Arabic theories that informed Maimonides, see Rosenberg, "Signification of Names in Medieval Jewish Logic." 
erate the words attem banim ("you are the sons"), an expression found in Deuteronomy 14:1, one of the most important biblical proof-texts for the divine sonship of the people of Israel. ${ }^{217}$ Accordingly, it is the act of intellection that is crucial for obtaining prophecy, rather than concrete religious deeds-namely, acting in accordance with the commandments-which count much less, if at all, for the attainment of the ultimate perfection. ${ }^{218}$

This subversive axiology dramatically prefers the spiritual over the corporeal, historical, and national axis or register and represents a deep tendency in Abulafia's thought insofar as many other topics are concerned, such as the question of creation ex nihilo or continuous creation, ${ }^{219}$ following some of the medieval philosophies with which the Kabbalist was acquainted. The proof of the need for such a spiritual understanding of the nature of the son in the parable is his description of him as lacking knowledge; his later repentance is most probably related to his acquisition of knowl-

217 Hayyei ha-Nefeš, 16; see also Idel, Language, Torah, and Hermeneutics, 109-10.

218 See, for the time being, Idel, "On the Secrets of the Torah," 430-51, and Abulafia, Mafteah haŠemot, 28-29.

219 This topic in Abulafia's thought deserves a separate inquiry. See Scholem, The Kabbalah of Sefer ha-Temunah, 183-84; Abulafia's fourth secret of part 3, in his list of secrets in the Guide, according to his three commentaries. See, especially, Hayyei ha-Nefeš, 99: העולם התמידי; Hayyei ha-Nefeš, 133: ומתחדש תמיד; Sefer Gan Na'ul, 40-41; Commentary on Sefer Yeșirah, 1-2; Oșar 'Eden Ganuz, 2:1, 207; and Mafteah ha-Sefirot, 16-17. See also Appendix E note 12 below. On this problem in general, see Harvey, “A Third Approach to Maimonides's Cosmology-Prophetology Puzzle,” especially 293-94, notes 22-23; Harvey, "The Mishneh Torah as a Key to the Secrets of the Guide," 15-17; Wolfson, Language, Eros, Being, 88; and Ravitzky, "Secrets of the Guide," 173. For sources mentioned by Rabbi Abraham ibn Ezra, see Genesis 1:1, Exodus 3:2, Exodus 20:20, and the short commentary on Exodus 20:1, which is possibly related to the views of the Muslim Ash'ari theologians. On this issue in Abulafia's generation, see Harvey, Falaquera's “Epistle of the Debate," 111-15; Ravitzky, “The Thought of Rabbi Zerahyah,” 221-63; Seymour Feldman's analysis of the somewhat later author Rabbi Isaac Albalag's view on creation in "An Averroist Solution to a Maimonidean Perplexity," Maimonidean Studies 4 (2000): 15-30; Seymour Feldman, "The Theory of Eternal Creation in Hasdai Crescas and Some of His Predecessors,” Viator 11 (1980): 289-320. On ibn Kaspi, see Hannah Kasher, “Joseph ibn Caspi as a Philosophical Exegete" [Hebrew] (PhD diss., Bar-Ilan University, 1982), 54-61. See also Norman M. Samuelson, The First Seven Days: A Philosophical Commentary on the Creation of Genesis (Atlanta: Scholars Press, 1992). On Maimonides's stance regarding the creation of the world, which likely influenced Abulafia, there are several studies. See Nuriel, Concealed and Revealed in Medieval Jewish Philosophy, 25-40; Israel Ravitzky, "The Question of a Created or Primordial World in the Philosophy of Maimonides” [Hebrew], Tarbiz 35 (1966): 333-48; Sara Klein-Braslavy, Maimonides's Interpretation of the Story of Creation; Hyman, "Maimonides on Creation and Emanation," 45-61; and recently Racheli Haliva, "The Origin of the World-An Anti-Sceptical Approach in Medieval Jewish Averroism," in Scepticism and Anti-Scepticism in Medieval Jewish Philosophy and Thought, 139-42. For a comprehensive treatment of this topic, see Herbert A. Davidson, Proofs for Eternity, Creation and the Existence of God in Medieval Islamic and Jewish Philosophy (Oxford: Oxford University Press, 1987). See also Laderman, Images of Cosmology in Jewish and Byzantine Art, 101-10. Compare also to the view of ibn 'Arabi discussed in Henry Corbin, Alone with the Alone: Creative Imagination in the Sufism of Ibn 'Arabi (Princeton: Princeton University Press, 1969; repr. 1998), 200-207. 
edge. ${ }^{220}$ Also, the gist of paragraph [c] deals with the spread of knowledge in the eschaton.

In any case, at least in one instance, Abulafia explicitly rejects the view that the people of Israel are to be understood solely as a corporate personality, that they are, in a genetic sense, a Son of God, as he points out in the threefold categorisation of sonship in his Sitrei Torah. ${ }^{221}$ In this context, it should be mentioned that in Or haSekhel, Abulafia refers to his two students to whom he dedicated the book as the sons of his intellect, which is not different from the sons of God. ${ }^{222}$ More than any other type of sonship, intellectual sonship constitutes the "true" meaning of the relationship between God and man. This also seems to be the essence of a brief comparison of the people of Israel to a son who does not listen to his father and is punished found in Hayyei ha-'Olam ha-Ba', a book written two years before Or haSekhel. ${ }^{223}$ In this case, the rebellious son is portrayed as unwilling to learn the truth, not merely as behaving badly.

However, what is important in this short anticipation of the pearl parable is the fact that immediately afterwards, Abulafia applies this type of rebellion to a person who is unwilling to recognise the truth. This is a transposition of the parable: the son, and the nation, according to the second narrative, becomes the individual standing before God, undoubtedly an intellectual type of relationship consonant with what I call the third type of narrative. ${ }^{224}$ This third narrative precisely fits an ecstatic Kabbalist in its details.

The future aspect of the pearl parable speaks about the son's repentance; namely, his acquisition of wisdom and his inheritance of the pearl. ${ }^{225}$ This parabolic part is

220 For the concept of repentance interpreted in strong intellectual terms, see Abulafia, Sitrei Torah, 38. See also Abulafia's text in Wolfson, Abraham Abulafia, 127.

221 For Abulafia as a son, see more below at the end of this chapter.

222 See Or ha-Śekhel, 3-4. Compare also to Oșar 'Eden Ganuz, 1:2, 55: דע בני חמודי ענף נפשי ופרי שכלי ("You should know, my cherished son, the branch of my soul and the fruit of my intellect"). Here, it is clear that he is referring to his students and not to his genetic descendants.

223 Hayyei ha-'Olam ha-Ba', 196.

224 Hayyei ha-'Olam ha-Ba', 196-97.

225 In Abulafia's Hebrew original, the sole term used is margalit, just as in the Hebrew translation of the passage of the introduction to the Guide that is cited above that influenced Abulafia. However, by reading Hames's correct English translation of Abulafia's parable in Like Angels on Jacob's Ladder, 67-68, where the English term “pearl” occurs, Pedaya retranslates it into Hebrew as peninah, most probably without reading or checking the Hebrew original, which indeed she chose not to cite or give a precise reference to. She then freely speculates about the possible connection between Abulafia's discussion about the alleged peninah and the famous Gnostic Hymn of the Pearl on the one hand, and that of Joachim of Fiore on the other. See her "The Sixth Millennium," 85-86. Interestingly, Abulafia himself never uses the Hebrew word peninah in his writings, only when quoting biblical verses or titles of books where the term is found. On the basis of such superficial associations, and unaware of the entire bibliography related to the pearl parable, it is easy to be "creative" and to invoke Gnosticism and Joachimism as significant parallels. This is just one example of the plight of Abulafia studies, which relies on secondary sources and translations that are not always reliable, even when the 
understood on the historical or national level as the redemption of the Jews and the recognition of their superiority by all the other nations. In another form, it is part of the parable of the three rings. This reading is no doubt part of a popular exoteric form of messianism, well-known in the Middle Ages and used by Abulafia in his writings on the rhetorical level. However, I assume the existence of an additional level: an esoteric one, which entails another form of redemption. Such a reading will parallel the interpretation of the son as an intellect; namely, the concept of sonship in a non-genetic sense.

\section{Messianic Valences in Abulafia's Interpretation of the Parable}

The end of passage [c] from Or ha-Śekhel has a clear messianic overtone that is worth explicating as part of my assumption that Abulafia was operating with more than one type of narrative. For this purpose, let me first present a text that stems from Abulafia's commentary on one of his own "prophetic books" written in the same period and in the same town that he wrote Sefer Or ha-Śekhel. The Kabbalist, who believes that he is a Messiah, distinguishes between three different meanings of this term:

The term Mašiah is equivocal, [designating] three [different] matters; [a] first and foremost, the true Agent Intellect is called the Messiah [...] [b] and the man who will forcibly bring us out of exile from under the rule of the nations due to his contact with the Agent Intellect will [also] be called Messiah. [c] And the material human intellect is called Messiah. This is the hylic ${ }^{226}$ intellect that is the redeemer and has influence over the soul and all elevated spiritual powers. It can save the soul from the rule of the material kings and their people and their powers, the lowly bodily desires. It is a commandment and an obligation to reveal this matter to every wise man of the wise ones of Israel ${ }^{227}$ in order that he may be saved, because there are many things that oppose the opinions of the multitude of the Rabbis, ${ }^{228}$ even more that differ from the views of the masses. ${ }^{229}$

original Hebrew versions of his books are easily accessible. See also chapter 5 note 170 above and chapter 25 note 45 below. This is but one example of the neglect of the study of documents and the vortex of speculations, generalisations, and exaggerations that have plagued some parts of Kabbalah scholarship in the last two decades.

226 Namely, the material, passive, or potential intellect. This elevated status of the hylic intellect may reflect Averroes's theory. Perhaps the resort to the singular form points in the direction of an intellect that is common to all men. In some other cases, Abulafia also uses the parallel term śekhel homri. It should be mentioned that Abulafia uses the term שכל אפשרי in his Mafteah ha-Šemot, 21; this term means the potential or possible intellect and was known in Hebrew sources through Averroes. See Rabbi Hillel of Verona, Tagmulei ha-Nefeš, 56, 72, and 73.

227 Thus redemption is restricted to a few people of Israel and not the entire people, as is the case of [b].

228 This phrase is found in the preface to the Hebrew translation of the Guide of the Perplexed: סכל 
Thus, three meanings of the term Mašiah are advocated: [a] the cosmic intellect that operates all the time and informs all the processes of intellection in this world, which are conceived as a salvific process from the point of view of the Neo-Aristotelian theories in the Middle Ages. This global or universal Messiah therefore saves all people who use their intellect, be they ethnic Jews or not. The particular human intellect is the Messiah, but it is now found in the individual [c]. Here again, a universal approach may be safely discerned because the intellect is not simply attributable to Jews alone.

Neither sense [a] nor sense [c] of Messiah, is, however, related to apocalyptic figures, nor to catastrophic changes, which are presupposed to be part of this type of redemption. It is only the second sense of Messiah as described in section [b]-namely, a person who will save the people of Israel-that is closer to the popular vision of the Messiah in Judaism, although in this case, it is connected to an intellectual type of activity: the cleaving to the cosmic intellect. This type of understanding of the Messiah is dependent on the Avicennian theory that assumes the possibility of changing Nature by cleaving to a higher entity, the supernal soul or the supernal intellect. ${ }^{230}$

Perhaps in this context, we may better understand a short passage from Abulafia's Untitled Treatise that is preserved in the Polyglota to the Psalms printed by Augustino Giustiniani, ${ }^{231}$ where it is written that "Constat vivificationem mortorum positam esse in manu Matatron, i. Messie"; ${ }^{232}$ that is, Metatron, who is reviving the dead, ${ }^{233}$ is also the Messiah. The last part of the sentence, "i. Messie," is not found

229 Commentary on Sefer ha-Meliș, Ms. Roma, Angelica 38, fol. 9a:

שתדע ששם משיח משותף לשלשה עניינים אלה. משיח יקרא תחילה השכל הפועל באמת [...] ומשיח יקרא האיש והעתיד

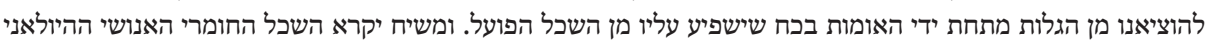

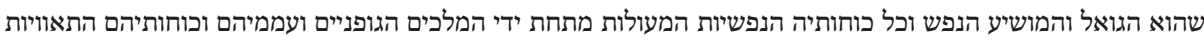

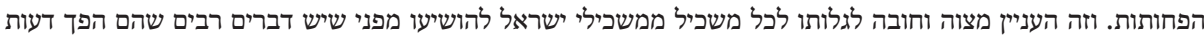
המון הרבנים, כל שכן שהם חולקים על כל מחשבות המון עמי הארצות.

On this passage, see Idel, Messianic Mystics, 65-68; Idel, Language, Torah, and Hermeneutics, 65-66; Idel, Studies in Ecstatic Kabbalah, 66; Idel, Ben, 308; Idel, "Abraham Abulafia: A Kabbalist 'Son of God," 74-75; Moshe Idel, "Multiple Forms of Redemption in Kabbalah and Hasidism," JQR 101 (2011): 39-42; Saperstein, Decoding the Rabbis, 112-19; as well as the observation of Wolfson, Abraham Abulafia, 54, note 149, and 91. This is not the place to trace the possible impact of these approaches to Hasidic concepts of redemption, including those of Habad.

230 See Ravitzky, History and Faith, 154-204.

231 Psalterium Hebraeum, Graecum, Arabicum, et Chaldaicum (Genoa: Pt. Porrus, 1516). On the relationship between some of those glosses to Abulafia's untitled treatise, see my remarks in "A Unique Manuscript," 27-28.

232 See the gloss on Psalm 147. The only Hebrew version extant in the Polyglota is מידוע כי ביד מטטרון תחית המתים, which means that $313+1=1313$ = $=314$ = 314 = תחית המטרון. On the identification of Metatron with Jesus, see Daniel Abrams, "Metatron and Jesus: The Long Durée of Rabbinic and Kabbalistic Traditions: An Eighteenth-Century Manual of Christian Proselytising in German and Yiddish," Kabbalah 27 (2012): 13-105. On other Kabbalistic material in the Polyglota, see now Avishai Bar Asher, "Isaac b. Solomon ibn Sahula's Commentary on Psalms” [Hebrew], Koveș 'al Yad 26 (2018): 1-46. 233 On Metatron and the resurrection, see Ms. Firenze, Laurenziana, Plut. II, 48, fol. 95a: 
in the Hebrew version of the Kabbalistic fragment and may be Giustiniani's addition. However, it fits Abulafia's allegorical approach as described above and its meaning should be understood within the framework of the Untitled Treatise; namely, that the realm of resurrection is a spiritual and not a corporeal phenomenon. ${ }^{234}$

Like some Maimonideans, ${ }^{235}$ Abulafia widely identifies Metatron with the Agent Intellect. ${ }^{236}$ This transposition of the traditional Messiah to the philosophical term is part of the parallelism between Abulafia and the Maimonideans, as has already been pointed out elsewhere. ${ }^{237}$ However, it is not just a matter of one more application of an exegetical allegoresis, as the Maimonideans did in some cases; it is part of his self-perception as a person with a special eschatological mission.

Interestingly enough, the faculty of imagination is not mentioned at all in this passage, most probably as part of the assumption that the unitive experience attained by the Messiah is conceived as being higher than that of the prophet, who needs imagination for his prophetic mission, nor is any theosophical concept operative in any of the three descriptions.

Obviously, the list of the three meanings is based upon an implied hierarchy that begins with the more general or universal understanding of the Messiah as a cosmic and universal entity understood to be the "true" one, [a]; then comes the national Messiah, which concerns many people but not everyone, since it is implied that he will only redeem the Jewish nation, [b], and finally comes the individual type of redemption that affects only a single person, [c]. Let me emphasise that all these forms of redemption are described in the context of the term "Messiah," and as such, they are all part and parcel of the constellation of messianic ideas. Although Abulafia at least understands the three meanings to be valid, though intended for different audiences, the intellectual register is evidently more important than the national one.

This type of discourse based on the exegetical principle of homonymy or equivocal terms was borrowed from Maimonides's Guide and also assumes different types of narratives: a national and historical one in [b] and an individual one in [a] and [c], as was suggested in chapter 13 above in the case of the parable of the pearl. It should be mentioned that in the description of the Messiah found in [c], there is an explicit instance of allegorisation. Also in this passage, we find Abulafia's disjunctive approach in which his views and those of the Rabbis and the multitude are explicitly described as opposing one another.

המלאך הנזכר המודיעו ליודעיו ובו נמצאת תחיה למתים ואמר בעדו שמי המיוחד לי ושם המלאך הנזכר בשם רבו [...] שבו תלה השם תחיית המתים והוא מטטרון.

234 See Idel, “The Time of the End.” This point is not acknowledged in Sagerman, The Serpent Kills, 248, when he discusses Abulafia's corporeal approach to resurrection as part of a Christian view. 235 See Idel, Messianic Mystics, 349, notes 26, 27; 351-52, notes 44, 46, 50.

236 Idel, "Definitions of Prophecy: Maimonides and Abulafia," 7-8.

237 See Saperstein, Decoding the Rabbis, 112-19, who correctly dealt with this passage in the context of other Maimonidean contemporary thinkers; see also Idel, "Types of Redemptive Activities," 25960; Idel, Messianic Mystics, 75, 77; as well as Wolfson, Abraham Abulafia, 54, note 149. 
This passage was written in the same period as Or ha-Śekhel. This means that a more complex understanding of Abulafia should be adopted, at least when dealing with the parable, which assumes some form of personal and spiritual redemption, not just one dealing with the national horizontal narrative. In a similar manner to the intellectual understanding of the human saviour [b], we read in another passage:

The prophet is necessarily called Mašiah because he is anointed with the supernal oil that is called "the oil of anointing" ${ }^{238}$ [...] with which he utilises the Names. Actually, the Mašiah must possess two qualities. The first is that he must be anointed by God with wondrous prophecy and the second is that he must continue to be consecrated by God and by the people, who will hail him as their great king for all time. And he will rule from sea to sea, ${ }^{239}$ and this is all due to the great intensity of his clinging to the divine intellect and his reception of the power, in a strong manner like the manner of Moses, Joshua, David, and Solomon. And the issue of the Messiah will be known by everyone, and this is the reason why there is no need to announce this issue more here, because he is destined to reveal himself soon in our days. ${ }^{240}$

There is no doubt that this imminent revelation is related to Abulafia's own eschatological mission. Two main attributes of the Messiah are mentioned here: prophecy and power. However, in this context, power depends not on brute force, military or otherwise, but on some form of high intellectual experience. The adherence to the supernal intellect allows the prophet, and implicitly the Messiah, to perform miracles that are understood as part of the laws of nature, following views found in the thought of Avicenna and Al-Ġazālī. ${ }^{241}$ Conspicuously, the true meaning will be revealed in the future, which means that it is currently unknown.

These passages and many others in Abulafia's writings reflect his emphasis on individual redemption being attained through clinging to the cosmic intellect, $a$ stage that was conceived as preceding his more public activity. In some other instances, Abulafia understood redemption in an interiorised manner as a form of spiritual awaking. ${ }^{242}$ Interestingly enough, in a fascinating passage from his Hayyei ha-Nefeš, Abulafia regards the dichotomy between the masses and the elite as forever unsur-

238 Presumably the supernal intellectual influx that descends upon the prophet and the Messiah. 239 See Zachariah 9:10.

240 See Abulafia's Sefer Mafteah ha-Tokhahot, his commentary on Deuteronomy, Ms. Oxford, Bodleian 1605, fol. 46b, 78:

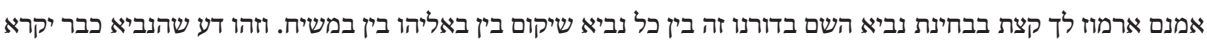

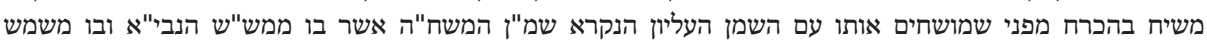

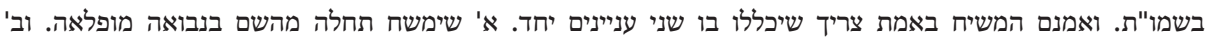

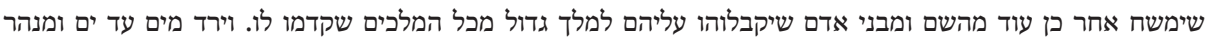

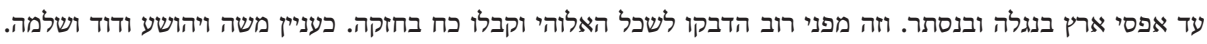

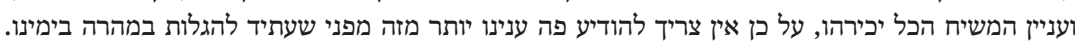
241 See Idel, Studies in Ecstatic Kabbalah, 63-71, which relies on a passage from Or ha-Śekhel. See also Ravitzky, History and Faith, 154-204.

242 Idel, “The Time of the End," 155-86, and Idel, "Multiple Forms of Redemption," 42-44. Let me point out that for Abulafia, in a manner reminiscent of East European Hasidism, the experience of personal redemption is understood as preceding general redemption. 
mountable, as an inherent part of human nature, in a manner reminiscent of Leo Strauss's more deterministic approach, or that of Averroes according to a certain interpretation, minimising the possibility of a general redemption which may have a noetic nature. ${ }^{243}$

Indeed, one of his contemporaries, the Provençal author Rabbi Isaac ben Yeda'ayah, had already asked the following question: if the Messiah's role is to enable people to philosophise, is it the case that one who can do so immediately and independently does not need a Messiah? ${ }^{244}$ Thus, the esoteric nature of redemptive noetics is far more determined by genetics and can hardly be significantly corrected, an approach that allows little room for a collective type of redemption in the vein of the second narrative, pushing to the forefront the individual redemption in the third narrative.

In a way, Abulafia combines the popular Messiah as part of the second narrative with the personal redemption of the third narrative; in other words, he combines the linear time of national eschatology with the atemporal nature of redemption according to the third narrative. The distinction between the two types of religiosity formulated by Eliade as belonging to exclusive religious modalities does not hold for Abulafia, who combines the linear-historical with an atemporal form of experience that has a strong ecstatic dimension. ${ }^{245}$ In other words, actual religious phenomena, unlike the abstract scholarly dichotomous distinctions in different categories, are always more complex, and Abulafia is indubitably an example of complex approaches.

This spiritual reading fits the manner in which the son is portrayed in the parable: in paragraph [b], he first lacks knowledge, then obtains it; knowledge is mentioned again quite conspicuously in [c], where the obliteration of imagination is described as part of redemption. This reading constitutes the contribution made by Maimonides's theory of knowledge to Abulafia's thought.

Let me turn to the description of the eschaton in the context of the parable in paragraph [c]. The situation of salvation is described as the state in which each person will contain all the others like his own limbs. We would do better to understand this view as part of the process that I designate as universalisation; namely, the expansion of the intellect of the individual so that he becomes identical with the whole, an issue to which we shall now turn.

\section{Universalisation, or the Vertical, Psychological Allegory}

In the lengthy passage from Or ha-Śekhel (quoted above in chapter 15), there are several terms that point to some form of universality: "universal speech," "universal re-

243 Hayyei ha-Nefeš, 126-27 and 77, and Idel, "On the Secrets of the Torah,” 397.

244 See Saperstein, Decoding the Rabbis, 110-11.

245 See also Idel, "Multiple Forms of Redemption.” 
ligion," and the recurrence of the term kol ("all”). The mention of the human species in this passage also points in this direction. In fact, the entire human race's ignorance of the divine name that occurs at the very end of the chapter does not allow for a significant difference between Jews and Gentiles.

These occurrences of terms related to "universals" in a relatively short text are too dense to be overlooked or underestimated. In my opinion, these terms, which convey a sense of being universal or general, constitute a major contribution to the meaning of the passage, and they should be interrogated in order that we may understand Abulafia's intent. More than any other Kabbalist with whom I am acquainted, Abulafia was especially fond of the language of universality; this theme occurs not only in his Or ha-Śekhel, but also in many other instances in his writings. For example, he refers to the "universal [or "general"] Kabbalah" and to the "universal prophecy" together with the knowledge of the Torah and commandments "in general."246

In another instance, he refers to the Agent Intellect using the term ha-Ruah haKelali (the "universal spirit"), ${ }^{247}$ and elsewhere, he describes the Agent Intellect as the "general power." 248 In an interesting discussion, Abulafia makes a numerical connection between the term kolel ("comprises") and ha-Teva' and Elohim, an important motif in his thought as shown in several instances above. ${ }^{249}$ In one case, he mentions the "universal nature," ha- Teva' ha-Kelali. ${ }^{250}$ Elsewhere, Abulafia discusses the principles (kelalim) of the secrets of the Torah, which should be hidden from the masses, versus their details, which are conceived as being even more dangerous to divulge. ${ }^{251}$ These are only some examples of Abulafia's reference to entities or concepts being general or universal.

In general, I would say that the more "universal" terms are more abstract and thus more difficult for the masses to understand, though they were of vital impor-

246 See his commentary on the book of Numbers, Mafteah ha-Sefirot, 56. Here, the general Kabbalah is related to the combinations of letters. See also Idel, The Mystical Experience, 185-86; Abulafia, Imrei Šefer, 150-51, 198; and Wolfson, Abraham Abulafia, 198-99. Implicitly, a universal or general Kabbalah is also referred to in Abulafia's Or ha-Śekhel, 85, and Oșar 'Eden Ganuz, 3:9, 381. See also Oșar 'Eden Ganuz, 3:9, 349, and Abulafia's “Ševa' Netivot ha-Torah,” 12. See my Language, Torah, and Hermeneutics, 12-13, 75, and 187, note 239, and Idel, Studies in Ecstatic Kabbalah, 5, 7 17 , and 23 , note 27 . The two narratives discussed above (the national exoteric one and the individual esoteric one) are reminiscent of Averroes's theory of double truth, an issue that deserves further investigation.

247 See Sitrei Torah, which is a seminal text that had a wide impact on Kabbalah. It is translated and analysed in Idel, Ben, 279-80.

248 Mafteaḥ ha-Šemot, 87: הכח הכולל. See also the important statement found in his Sefer ha-Hešeq, 1.

249 See above chapter 17 note 132 and chapter 18 note 196; see also Idel, Absorbing Perfections, 261. 250 Or ha-Śekhel, 108.

251 Introduction to Mafteah ha-Hokhmot, 6, translated above as a motto. This is an extremely important discussion because the details contradict the specific tenets or beliefs of the vulgus. 
tance for Abulafia's own type of religion. As I proposed elsewhere, ${ }^{252}$ it would be helpful to distinguish between examples of mystical union experiences described as a process of universalisation over and against others that can be understood as describing a sense of integration; Abulafia's expressions belong to the former in quite an obvious manner.

In an interesting statement that deals with a seminal hermeneutical principle, Abulafia asserts that "the hidden" matters are general by necessity and that the plain sense involves particulars, since all the particulars are built on the senses, like the particulars that the senses apprehend, but the secrets are all general intellectual matters and it is subsequently necessary that there are many parts in the plain sense.”253 Thus, following Maimonides, the general is abstract and unifies many contents of the particulars, and as such, they are unseen, hidden, or secret, while the particulars are obviously a matter conceived by the concrete senses and thus they are part of the plain sense of the text understood by people who do not possess the intellectual power of abstraction. ${ }^{254}$ Here, it is obvious that the hidden matters -namely, the secrets that belong to Abulafia's Kabbalah-should be understood within the framework of Neo-Aristotelian noetics, which regards the understanding of the general or the principles as a much more noble type of perception than the understanding of concrete details.

Although the "general Kabbalah" is a rather rare term, it occurs in several Kabbalistic texts written before and after Abulafia. ${ }^{255}$ It runs against the manner in which earlier Kabbalists, especially Nahmanides and his disciples, understood Kabbalah as dealing with specific details that cannot be expanded by a person's intellectual activity, but which should be carefully transmitted orally from mouth to mouth. ${ }^{256}$ They

252 See Idel, "Universalization and Integration," 27-58. Let me point out that my use of the term "integration" differs from that of Wolfson and Sagerman. I speak in this text about the integration of a lower entity within a greater entity as part of a mystical union that still allows for the retention of some form of individuality. The two other scholars use integration in a manner closer to psychology, as a bringing together of two entities that generates something higher.

253 Mafteah ha-Hokhmot, 43:

כי הנסתרות הן כלליות בהכרח והפשטים הם פרטים וזה מפני שהפשטים כלם בנוים על הרגשות כמו הפרטים שההרגשים

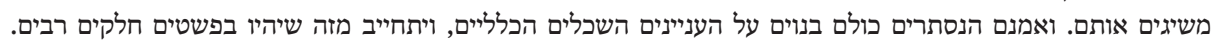
On the assumption that general principles are atemporal and eternal, see Abulafia's Commentary on Sefer Yeșirah, 19, which is translated and discussed in Appendix E.

254 See Maimonides’s Guide 1:73, Pines, 1:209.

255 See the material I referred in Moshe Idel, "Kabbalistic Material from Rabbi David ben Judah heHasid's School,” [Hebrew], JSJT 2 (1983): 177-78, note 40. A history of this term is a desideratum for understanding the varieties of Kabbalah in the thirteenth century.

256 See Moshe Idel, “Nahmanides: Kabbalah, Halakhah and Spiritual Leadership," in Jewish Mystical Leaders and Leadership, eds. Moshe Idel and Mortimer Ostow (Northvale: Jason Aronson, 1998): 15-96; Idel, “'In a Whisper,” 467-77; and Daniel Abrams, “Orality in the Kabbalistic School of Nahmanides: Preserving and Interpreting Esoteric Traditions and Texts," Jewish Studies Quarterly 2 (1995): 85-102. See also Abulafia, Hayyei ha-Nefeš, 4: גם באזני המשכילים בכל יום ויום ילחשם (Also, he should whisper them in the ears of the illuminati each and every day”). 
deal with particulars in the biblical texts, not with principles. On the contrary, Abulafia encourages his reader to unveil what he has hidden and conceives his Kabbalah to be intellectual and dependent on the activity of the intellect.

Of special importance is the discussion found at the end of Abulafia's Sefer haHešeq, where he writes about "the influx that he [the recipient] will receive and from which he will comprehend the form of the universal wisdom, without time." ${ }^{257}$ The timeless reception of the universals corresponds to what I call the transhistorical narrative. The concept of "universal grace" (Hen kelali, quite an exceptional phrase in Jewish mysticism that perhaps reflects a translation of the Christian "charisma"), which is also described in the same context as "divine," points in the same direction: an interest in universality. ${ }^{258}$

In his commentaries on the books of Genesis, Exodus, and Deuteronomy, Abulafia speaks about the "general and particular ways" of understanding the Bible, 259 while in his Oșar 'Eden Ganuz and Imrei Šefer, it is the technique of combining letters that is called the "general way."260 The concept of the "universal [or "general"] secret" (ha-sod ha-kelali) recurs in two of Abulafia's writings and contributes to the spectrum of expressions that refer to universality. ${ }^{261}$ No doubt the attainment of the state of totality is regarded as an ideal, and is in any case superior in comparison to that of the particular. ${ }^{262}$ By becoming universal, the particular entity expands itself and is substantially transformed, assuming a new status described as a divine spe-

257 See his Sefer ha-Hešeq, 61 and 80. "Universal wisdom" is a term Abulafia probably took from his teacher Rabbi Baruch Togarmi's Commentary on Sefer Yeșirah (cf. Scholem, The Kabbalah of Sefer haTemunah, 233), as has been pointed out in Wolfson, "Kenotic Overflow and Temporal Transcendence," 189, note 208. The term itself is reminiscent of the approach that has been designated since the seventeenth century as pansophia, one of whose main representatives was Leibniz. See Sorin Antohi, Utopica: Studies on the Social Imaginaire, 2nd ed. [Romanian] (Cluj-Napoca: Idea, 2005), 160-61.

258 See Abulafia's Šomer Mișwah, Ms. Paris, BN 853, fol. 57a, 24, and Wolfson, Abraham Abulafia, 223. On Hen as a higher attainment than prophecy, see Hayyei ha-Nefeš, 159.

259 Mafteaḥ ha-Hokhmot, 103; Mafteaḥ ha-Šemot, 164-65; Mafteaḥ ha-Tokhaḥot, 124-25; and Sefer ha-Hešeq, 1.

260 See, respectively, 1:1, 2, 1:10, 79, and 198.

261 Namely, Hayyei ha-'Olam ha-Ba' and Sitrei Torah, both written during the same period (127980). See also Wolfson, "Kenotic Overflow and Temporal Transcendence," 172-78. See also Abulafia, Or ha-Śekhel, 29. For an interesting reverberation of the issue of the universalisation of the perfect man, see the anonymous Sefer Toledot Adam, Ms. Oxford, Bodleian 836, fol. 165a: "Since he comprises them together as he already became universal, and this is the reason why he can innovate forms in matters and perform wonders and miracles, since he is the absolute righteous."

262 Compare, however, the opposite interpretation of the concept of "universal speech" given in Wolfson, Venturing Beyond, 61: "An elocution that denotes not language in general or the potentiality for language as such, but rather the specific ethno-cultural linguistic comportment of the Jewish people, Hebrew, the language of creation, revelation, and redemption." However, he did not present or adduce any support for this claim. This surprisingly particularistic interpretation of the text reflects Wolfson's attitude not only to Abulafia's interpretation of the parable, but also to Abulafia's thought in more general terms; see his "Deceitful Truth, Truthful Deceit," $114^{\star}-15^{\star}$. 
cies. This radical type of transformation does not constitute an event that may only take place in the eschatological future-given that the universal speech and religion have already been referenced in paragraph [a] as a matter of the past-but one that may also occur in the past and the present.

In my opinion, it is in the context of Abulafia's emphasis on the universal that the following passage should be understood:

In the perfect man [ha-iš ha-šalem] whose intellect has been actualised, his liver, heart, and head, that is, his brain, are one thing until the vegetative soul and the master of knowledge [ba'alat ha-da'at] discerns, knows, understands, and comprehends how to govern her matter according to God and not according to nature alone. The efflux overflows from the world of angels to the world of the heavenly spheres and from the world of the heavenly spheres to the world of mankind, until the point that the distinguished universal person ${ }^{263}$ becomes intellectualised in actuality. Analogously, the verbal, intellectual overflow that is in the brain overflows from the head to the heart and from the heart to the liver. ${ }^{264}$

It is evident that the "perfect man" (ha-iš ha-šalem ${ }^{265}$ ) at the beginning of the passage is parallel to what I translate as a "distinguished universal person" later in the passage; Wolfson translates it as "particular universal." In both cases, an individual person who has actualised his intellect is intended.

Based on this passage, Wolfson understands Abulafia's view to be generally dealing with the special ethnicity of the Jews as a nation, as well as with the chosenness of all the Israelite nation; thus, he imposes a particularist position not just on this specific passage, but also on this Kabbalist as a whole. Wolfson writes quite eloquently as follows: "The mark of their chosen position vis-à-vis the other nations in virtue of which they are the 'universal particular' (ha-meyuhad ha-kelali), that is, the particular ethnicity that can actualise the potentiality of human beings to become universal by receiving the intellectual overflow of the logos." ${ }^{266}$ However, nothing can be further from the intention of Abulafia's passage than the ethnic-particularistic interpretation offered here by this scholar. The term meyuhad in this

$263 \mathrm{Ha}$-meyuhad ha-kelali. My translation differs from Wolfson's rather oxymoronic phrase "particular universal."

264 Oșar 'Eden Ganuz, 2:1, 200:

והאיש השלם אשר יצא שכלו לפעל שבכבדו ולבו וראשו כלומר מ[י[חו דבר אחד, עד שהנפש הצומחת ובעלת הדעת מכרת

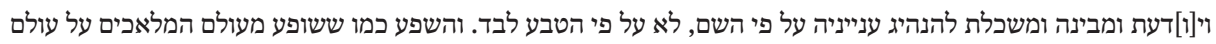

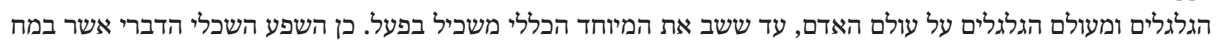
משפיע מן הראש אל הלב ומן הלב אל הכבד. In general, I have used Wolfson's translation from Venturing Beyond, 72, with one major exception, mentioned in the previous footnote. The three organs mentioned at the end of the quote are considered to be the principle organs and are treated as such in several of Abulafia's writings. See "We-Zot li-Yehudah,” 24-25, and Šomer Mișwah, 15.

265 In many of his writings, Abulafia speaks about the "perfect man" as an individual and not a nation, comprehensive unit, or hypostasis. See Sitrei Torah, 61; Mafteah ha-Hokhmot, 78; and Sefer haMelammed, 16. See already Maimonides’s Guide 1:73, Pines 1:91-92.

266 Wolfson, Venturing Beyond, 73. 
specific context does not mean "particular," as Wolfson quite questionably translates it following modern Hebrew; in medieval Hebrew, it means "special," "outstanding," "exalted," or “distinguished," as in Abulafia's thought, and in his worldview only the distinguished person can be designated as universal. ${ }^{267}$

Therefore, it stands not for a whole nation, as indeed the parallel to the phrase (the phrase "perfect man") demonstrates. The fact that he is described as intelligising shows that this is a process that can only be tangentially linked to a national unit in a Neo-Aristotelian framework. Universalisation is related to the intellect and definitely transcends ethnicity, as intellection is conceived both by medieval philosophers and by Abulafia as a specific quality of the human species; evidently, it cannot therefore be restricted to Jews alone. This is clear from the passages quoted in this chapter from Oșar 'Eden Ganuz. However, in order to prove my point still more, let me compare the above passage to a parallel found in another of Abulafia's books:

All that which is interpreted according to the hidden path [ha-derekh ha-nistar] points to a deeper wisdom and is more beneficial to the distinguished person ${ }^{268}$ than the teaching of the plain

267 See the passage from Sitrei Torah immediately below in chapter 21 note 305, where the phrase מיוחד כולל ("distinguished and comprehensive") occurs. For the meaning of ha-Meyuhadim (a technical term referring to intellectually developed persons), see the Commentary to Sefer ha-Yašar, 106. See also Sefer ha-Hešeq, 1, where he claims that in each generation a certain individual-described as a prophet or king-becomes universal as part of his leadership. Compare also to the interesting discussion in Or ha-Śekhel, 29, and Sitrei Torah, 111. See also the next footnote.

268 Ha-iš ha-meyuhad. The source of this specific use of the term meyuhad is Samuel ibn Tibbon's translation of the Guide 1:14, trans. Pines (1:40), as an "[outstanding] individual” that is in opposition to hamon, "the multitude." In his commentary on the Guide, Yehudah Even Shmuel correctly interprets meyuhadim as yehidei segullah. See Moreh Nevukhim la-Rambam (Tel Aviv: Shevil, 1935), 83. In Give'at ha-Moreh, Solomon Maimon reads it as ḥašuvim ("the important ones"). On this phrase referring to a distinguished individual, see also Abulafia's "Ševa' Netivot ha-Torah," 4, 9; Oșar 'Eden Ganuz, preface, 2, and 3:9, 354 (which is a passage that was quoted in chapter 10 above); Hayyei ha-Nefeš, 9 and 15 (discussed in chapter 8 above); Oșar 'Eden Ganuz, 1:8, 173; and Idel, "On the Secrets of the Torah in Abraham Abulafia," 388 and note 64, where I discuss Abulafia's gematria of meyuhad $=68$ = hakham ["wise"] = ha-navi' ["the prophet"] as found in Hayyei ha-Nefeš, 9. See also the very important discussion of the "distinguished man" in Idel, "On the Secrets of the Torah in Abraham Abulafia," 128. These gematrias define the meaning Abulafia attributes to the distinguished individual. For another important passage where the "perfect man" is described as comprising everything (makhil ha-kol), see Imrei Šefer, 121, translated into English by Wolfson in "Kenotic Overflow and Temporal Transcendence," 172-73, and dealt with immediately below in chapter 21 note 301. Compare this concept to the more common expression found in Islam, al-insān al-kāmil (a concept that is connected to a prophet in some way), approximating the later Hebrew ha-adam ha-šalem, a phrase that also occurs in Abulafia's writings, sometimes in the context of universalisation. For example, see Commentary to Sefer ha-Yašar in Mașref ha-Śekhel, 99. For the closest parallel to Abulafia, see the view of ibn 'Arabī, as described in Annemarie Schimmel, And Muhammad Is His Messenger: The Veneration of the Prophet in Islamic Piety (Chapel Hill: University of North Caroline Press, 1985), 314, and Paolo Urizzi, "L'uomo teomorfico secondo ibn 'Arabi," in Il Fine ultimo dell'uomo, eds. Patrizia Spallino and Paolo Urizzi (Palermo: Officina di studi medievali, 2012): 151-87, especially 167-68, 
sense, since the plain sense is written for the benefit of the entire people, who have no reason to distinguish between truth and falsehood, but this is not useful for a person who has intelligence and is in search of the felicity that is unique to the intellectual power. ${ }^{269}$

In both cases, the term meyuhad is used in the context of an intellectual person, namely one whose intellect has expanded; however, in the latter passage, it is clear that this term stands in stark opposition to the "entire people." In other words, the particular nation does not become universal, but rather only a select few of its members who alone are capable of actualising their intellect.

Ethnicity has nothing to do with the intellectual achievement of one or some of those who belong to it. The individual member alone may become universal, but the nation remains particular, even if chosen, though this choice should be understood in the manner discussed above. Though Abulafia does speak about the "special [or "distinguished"] nation" (ha-ummah ha-meyuhedet), ${ }^{270}$ this specialness is not genetic, but is dependent on the nation which possesses the tools that help it to attain the knowledge of God: the language and the script. Nothing ethnic is mentioned here, except the resort to two sorts of tools that can be acquired by anyone, Jew or Gentile, but which are especially known to the Israelites. In other words, a Jew who does not know Hebrew or the Hebrew script is hardly conceived as being part of the distinguished nation, while a Gentile who knows them should be.

On the basis of his erroneous interpretation of Abulafia's view in Oșar 'Eden Ganuz, as well as his equally mistaken interpretation of Abulafia's position on the cessation of pollution discussed in chapter 9 above, Wolfson goes one step further, claiming that on the point of ethnicity, or what he calls "Israel's ontic status," there is no difference between Abulafia's view and those Kabbalists who wrote the Zohar! ${ }^{271}$ This leitmotiv of an alleged similarity between these Kabbalistic corpora that is recurrent in recent scholarship ${ }^{272}$ is based on flawed analyses of basic Kabba-

note 82. Let me be clear: in Abulafia's writings, the term meyuhad also has the meaning of "special," "particular," or "unique," depending on the context in which this term is used.

269 Or ha-Śekhel, 39-40:

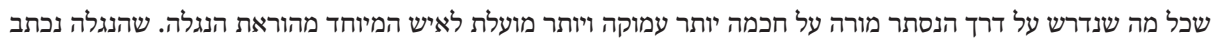

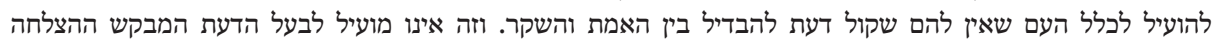

המיוחדת בכח הדברי.

Compare to Oșar 'Eden Ganuz, 3:10, 361, where the distinguished person is again explicitly juxtaposed with the multitude. Let me point out that the distinction between the "distinguished individual" and the masses, he-hamon, is reminiscent of Erich Neumann's theory based on the evolution of the individual and the loss of individuality through becoming part of mass events, which he calls re-collectivisation. See his The Origin and History of Consciousness.

270 See Or ha-Śekhel, 33, 34, translated in the context of the parable of the pearl, in "Ševa' Netivot ha-Torah," 9; Oșar 'Eden Ganuz, 1:10, 192; and Oșar 'Eden Ganuz, 2:1, 200, 207.

271 Venturing Beyond, 73.

272 See Pedaya, “The Sixth Millennium.” The problem with scholars' comparisons of Abulafia's Kabbalah with the Zohar is the former's understanding of national redemption as a lower register, as found in traditional Judaism and in the Zohar, while his esoteric, noetic, and individual register, 
lah texts, particularly those of Abulafia, as well as on a type of comparativism that is exceedingly tendentious and which loses the general structure of the framework of the specific discussions therein. ${ }^{273}$ Thus, these interpretations generate lamentable generalisations about the characteristics of Kabbalah as a whole. Without understanding the conceptual frameworks that are characteristic of Abulafia's ecstatic Kabbalah and those of the Zoharic literature, it is meaningless to deal with details when detached from their wider contexts.

Let me turn to a seminal passage from Abulafia's last book, which deals with the perfect man:

The purpose of the intention of the existence of man is his knowledge of himself and of his essence, that is, in the form of $Y$ according to its form and also according to its name, $Y$ [od]; namely, the assembly, the bringing together of everything, ${ }^{274}$ which is the secret of Knesset Yiśra'el, whose secret is $Y \check{S} a R^{\prime} \mathrm{eL},{ }^{275}$ since the perfect man brings everything together and is called Qehillat Ya'aqov. And the essences from all are the ten souls, in accordance with the assembly of the ten sefirot within the sefirah of Šekhinah, which is an impregnable woman, and she received everything from All, and her name is Sedeq according to its masculine [aspect] and Sedaqah according to its feminine [aspect]. ${ }^{276}$

The main subject matter of the passage is the perfect man, whose main feature, or essence, is his comprehensiveness. He is all, comprises all, and receives all. Let me analyse the Hebrew terms applied to him and how Abulafia understands their qualifications of the perfect man: $Y$ stands for the Hebrew letter Yod, whose numer-

speaking about an atemporal state, is ignored by both scholars and the Zoharic literature. The issue of the sixth millennium, or similar computations, may simply belong to the lower, national register. What is missing in the Zoharic discourse is what is especially characteristic of Abulafia's thought, the atemporal, individualistic, and esoteric noetics.

273 For examples of the stark divergences between Abulafia's imagery of the Torah and those found in theosophical-theurgical Kabbalists, see Idel, Language, Torah, and Hermeneutics, xiii-xv. For the divergent theories of the nature and role of the soul and intellect in those two schools, see also my "Nišmat Eloha: The Divinity of the Soul in Nahmanides and His School" [Hebrew], in Life as a Midrash: Perspectives in Jewish Psychology, eds. Shahar Arzy, Michal Fachler, and Baruch Kahana (Tel Aviv: Yediot Aharonot, 2004): 338-80. See also part V below.

274 I assume that the meaning is that this number, 10, is the sum of $1+2+3+4$, which precede it. See Oșar 'Eden Ganuz, 3:9, 352-53: "Like $Y$ that is the general principle, that is derived from what precedes it, referring to the assembly of the ten and the collection of the powers of Malkhut, and its name is Qehilat Ya'aqov, that is called Y-śra'el, Y-a'aqov; namely, $Y$ end.” See also chapter 21 note 308 above. כמו י' שהוא כלל שהתחייב מהרכבת מה שקדם לו ומורה על קבוץ העשר ועל אסיפת כחות המלכות ושמה קהלת יעקב,

שנקרא י' שראל י' עקב כלומר י' סוף. שרת מרוף

275 Here, the term "secret" stands not for numerical equivalences, but for the ontological entity that is designated by the two terms "Agent Intellect."

276 Imrei Šefer, 121:

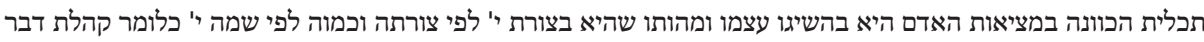

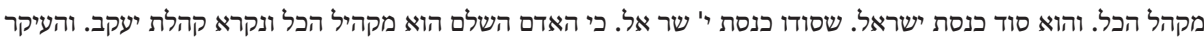

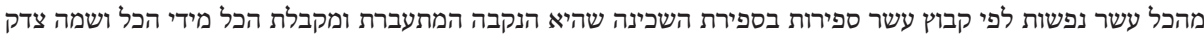


ical value is ten, ${ }^{277}$ conceived as the greatest of the numbers. It should be mentioned that in several cases in this book, the sefirot are compared to the first ten Hebrew letters. ${ }^{278}$

Knesset Yiśra'el literally means "the assembly of Israel," and in the Rabbinic sources, it stands for the hypostatic manifestation of the people of Israel as part of the particularistic approach. However, here, it stands for bringing together within man the powers of the supernal intellect (the Agent Intellect), which is equated to Yiśra'el in many Abulafian texts, ${ }^{279}$ even more so given the fact that the term Yiśra'el begins with Yod. Also present in this passage is the biblical phrase Qehillat Ya' $a$ $q o v,{ }^{280}$ which means "the community of Jacob." This phrase reflects a mode of semiotics parallel to Knesset Yiśra'el because the first word also means "assembly," while -so I assume-the second word, Ya'aqov, may refer to the Agent Intellect. ${ }^{281}$

Abulafia then turns to the idea of man comprising the ten souls (I assume the ten souls of the spheres according to Avicenna), ${ }^{282}$ which is a philosophical theme that is here connected to a theosophical one; the convergence of the ten sefirot within the last, the Šekhinah, described as female. In this last context, Abulafia also makes use of the theosophical theme that the Šekhinah is described as "all" and receives influx from All; namely, the male power, Yesod. This view is also found in Nahmanides's type of symbolism. ${ }^{283}$ Interestingly enough, the term "secret" occurs twice in the context of the philosophical terminology, but not in the context of the theosophical one. This means that the interpretation of the traditional terms as referring to the Agent Intellect is a secret, but the theosophical aspects of the discussion are not.

The manner in which the Šekhinah is described, as "a woman who cannot be impregnated," follows a view found in Geronese Kabbalah. ${ }^{284}$ However, Abulafia is less concerned with the gender distinction than he is with the fact that the Šekhinah is conceived as comprising something that comes from the outside and is found within the human soul or intellect. In theosophical Kabbalah, the distinction between the male and female attributes is ontological and the interaction between them is described using sexual terminology. For Abulafia, however, these sexual differentiations are obliterated: he describes the Šekhinah in terms which are either male or female. It should be mentioned that he does not take this type of symbolism as his own

277 See also Imrei Šefer, 62.

278 See Imrei Šefer, 106-7.

279 See Idel, "Definitions of Prophecy: Maimonides and Abulafia," 9-11; compare to Wolfson's alternative analysis in "Kenotic Overflow and Temporal Transcendence," 172-73.

280 Deuteronomy 33:4.

281 For Jacob as the Agent Intellect, see Sagerman, The Serpent Kills, 41.

282 See also chapter 6 note 257 above.

283 See Gershom G. Scholem, On the Mystical Shape of the Godhead: Basic Concepts in the Kabbalah, trans. Joachim Neugroschel, ed. Jonathan Chipman (New York: Schocken, 1991), 171-72.

284 See Idel, “Commentaries on the Secret of "Ibbur' in 13th-Century Kabbalah,” 21. 
view, as we learn from another passage concerning some other Kabbalists in the same book:

And they call the name of one of the sefirot "will," but did not find a way to call it created and did not find a way to call it pre-eternal, and this also happened to them with the name "thought," which they called the "supernal crown," which according to them is the first sefirah, but the tenth according to them is Šekhinah, and they call it Ședeq, and the names are known from their books, but they are very confused by them. ${ }^{285}$

This statement is not written as part of a polemic against Kabbalists, but rather as his own view that their theory of the sefirot and their symbols are part of a confusion; included in this confusion is the theme that Abulafia uses when discussing the Šekhinah quoted earlier. The distance between the views he presents as belonging to others and the views that are probably his own is quite obvious, as he insists on specifying that the former are "according to them" several times in a short passage.

Indeed, let me remind the reader what the main topic of the passage is: the comprehensive nature of the perfect man. The biblical, Rabbinic, philosophical, and theosophical themes are brought together to make an important claim: everything spiritual is found within the perfect man; this is the reason why a person who knows himself can know everything. ${ }^{286}$ This explains why these different terminologies were brought together and, in my opinion, why they were subordinated to what constitutes the centre of the translated passage.

Though written in Hebrew and resorting to a variety of Jewish themes, there is nothing specifically ethnic in this description of the perfect man. The only operation mentioned here is the act of knowing oneself, which is a famous Greek imperative. However, interestingly enough, in this case, the knowledge of God, a topic that is related to self-knowledge, is not included. Unlike the other interpretations of the Delphic maxim, Abulafia's passage emphasises comprehensiveness-which in my opinion is another version of universalisation-as the main quality of the perfect man. This perfect man transcends any particular ethnicity.

This hierarchy of the particular and the universal is not only a matter of lower versus higher forms of experience, but also of an ontological scheme that conceives the universal as occupying a higher ontological status than the particular. In the vein

285 Imrei Šefer, 18:

וקוראים שם אחת מהספירות רצון ולא ימצאו בעצמם דרך לקראו נברא גם לא ימצאו דרך לקראו קדמון וכן קרה להם בשם

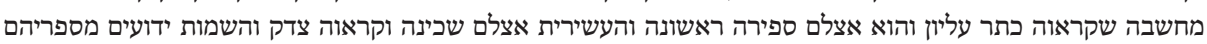

והם נבוכים בהם מאד.

The resort to the adjective "confused" shows that he reverted to Maimonides's attitude towards those who do not understand the real nature of Judaism. For someone actively involved in disseminating the Guide, the other Kabbalists are conceived as intellectually inferior and perplexed. See my discussion of Abulafia's critique of the other Kabbalists' concept of the ten sefirot in Appendix C.

286 See Alexander Altmann, “The Delphic Maxim in Medieval Islam and Judaism," in Von der mittelalterlichen zur modernen Aufklärung: Studien zur jüdischen Geistgeschichte, ed. Alexander Altmann (Tübingen: Mohr Siebeck, 1987): 1-33. 
of the Neo-Platonic approach, the main type of transformation is that of the particular soul into a universal soul. In some cases, it also includes the ascent of the lower and particular to the higher and universal source. However, Abulafia prefers to speak about the transformation of the intellect rather than the soul. ${ }^{287} \mathrm{He}$ explicitly indicates that the human intellectual faculty gradually "ascends" to the Agent Intellect, a metaphorical nousanodia, and is probably also united with God as an intellect. In other words, Abulafia operates with a well-defined ontological hierarchy, an elitistic anthropology and a series of seven methods of interpretation starting with the lowest, the narrow vulgus, and culminating with the prophets, the most comprehensive and universal. Without taking these hierarchies into consideration, it is difficult to appreciate the specificity of Abulafia's thought. Let me remind the reader that the last quote stems from a book written after 1290, the date for the coming of redemption according to Abulafia, which means after the time that the national redemption had not materialised.

In Abulafia's Sefer Sitrei Torah, the commentary on the secrets of the Guide written a few years before the composition of Or ha-Śekhel, we read: "And will unite with it [the Agent Intellect] after many difficult, strong, and mighty exercises, until the particular and personal prophetic [faculty] will turn universal, permanent, and everlasting, similar to the essence of its cause, and he and He will become one entity."288 This is not a union in which the particular identity of the interacting factors is preserved, but a complete transformation of the particular intellect into a universal entity that Abulafia imagines to happen in that moment. It is not very plausible that an individual existence could maintain itself or survive the post-mortem state of existence. Indeed, the eternity mentioned here assumes a transcendence of time, an issue that will be addressed in more detail in Appendix E.

Elsewhere in the same commentary, he writes: "You should meditate on his [Maimonides's] words in an intellectual manner, because of them, you should separate

287 See Ḩayyei ha-Nefeš, 60.

288 Ms. Paris, BN 774, fol. 155a, 138:

וידבק בו אחר ריבוי הרגל חזק ואמיץ, עד שוב הנבואי האישי החלקי בצורת סיבתו כללי תמידי נצחי כמוהו ויהיה הוא והוא

דבר אחד.

This process of universalisation through cleaving to the supernal spiritual realm also means an experience of atemporality. See the passage from Ner Elohim translated in Idel, The Mystical Experience, 125, where the assumption that it is possible to enter God is discussed. See also Sefer Toledot Adam, Ms. Oxford, Bodleian 836, fol. 165a, translated in chapter 21 note 261 above. See also Oșar 'Eden Ganuz, 3:8, 337. For the indifference to what I call "shared time" (the traditional time defined by the Jews' participation in the weekly cycle with the Sabbath as a special type of time shared by God and other Jews) in Abulafia, see Idel, "On Paradise in Jewish Mysticism," 625-35. According to Abulafia's Untitled Treatise, the separate "intellects do not fall under the [category of] time." See Ms. Firenze, Laurenziana, Plut. II, 48, fol. 80a: שהשכלים בעצמם לבדם אינם נופלים תחת זמן. On this treatise and its relationship to Abulafia, see my "A Unique Manuscript," and Appendix A. On Abulafia and simplification or depersonalisation of the mystic, see Idel, Studies in Ecstatic Kabbalah, 18-19. See also Idel, “Abraham Abulafia: A Kabbalist 'Son of God,” 90, note 117. 
yourself from the entire species, the general [species of] man, and you will become for God, a distinguished and comprehensive [one], and you will be called by the name 'Living God,' and you will become similar to God." ${ }^{289}$ We have here a transition from one sort of universality to another, from the natural one of the species to a divine one. By this process of intellectual universalisation, the individual intellect becomes not only eternal, but also universal, which means the combination of what used to be individuals into one universal being, which thereby obliterates individuality. In fact, the return from this state of union, or the reluctance to experience it, is described in two discussions as an act of rebellion against God. ${ }^{290}$

When describing what he refers to as the "real operation" (human transformation) at the end of his longest book, Oșar 'Eden Ganuz, Abulafia writes about "the secret of the true operation that changes the nature of the parts of beings by virtue of all speech[es], so that your intellectual spirit will become all after it was a part, and it will comprise in you all the substances of the species from your species, a fortiori what is beneath your species."291 The "true operation," a term that occurs again in a similar context in his book, ${ }^{292}$ refers to the change of nature; however, it is quite obvious that the nature intended here is none other than the human spirit or inner nature. ${ }^{293}$

This means that when compared to the changing of the external nature, the change of the inner nature-the spirit-is conceived as being much more important.

289 Sitrei Torah, 188:

התבונן בדבריו התבוננות שכליי ותיבדל בעבורם מכל מין האדם הכללי, ותשוב אצל השם מיוחד כולל, ותקרא אז בשם אלהים חיים, ותתדמה לאלהים.

Compare to the description of transformation into a divine species in the Commentary on Sefer haMeliș, translated in chapter 8 note 66 above, the discussion in the Untitled Treatise preserved in Ms. Firenze, Laurenziana, Plut. II, 48, fol. 83a, and the view found in the anonymous text in Ms. Sasoon 290, 235: "From the side of his knowledge, the one who comprehends it will become a separate intellect, and this is the reason for his survival, that is the best that it is possible to achieve" (שמצד (ידיעתו ישוב המשיגו ממנו שכל נפרד והוא סבת ההשארות המעולה שאפשר להשיגה (). On the authorship of this short anonymous treatise, see Idel, “Abraham Abulafia's Works and Doctrine,” 6. See also Appendix E. For the possible Maimonidean source that regards "Elohim" as angels-that is, the separate intellects-see Mishneh Torah, Hilekhot Yesodei ha-Torah 4:6, 7:1, etc., which was pointed out to me by Warren Zev Harvey.

290 See Hayyei ha-Nefeš, 142, and Hayyei ha-'Olam ha-Ba', 196-97.

291 Oșar 'Eden Ganuz, 3:10, 364, corrected according to the unique manuscript:

סוד הפעל האמתי המשנה טבע חלקי היצור בכח כלל הדבור, עד שישוב רוחך השכלי כל אחר היותו חלק ויכלול עצמך כל

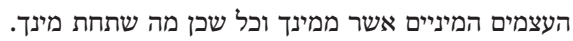

292 See Oșar 'Eden Ganuz, 3:10, 361, 366, which concerns the transformative type of ecstatic experience. On page 361, the transformation of the part into "all” is mentioned. See also Imrei Šefer, 72, where the particular soul is described as becoming universal or comprehensive of all souls (כפש by the activity of the Agent Intellect. On the topic of the transformation of the self in religion, see the studies collected in David Shulman and Gedalyahu G. Stroumsa, eds., Self and Self-Transformation in the History of Religion (Oxford: Oxford University Press, 2002).

293 See also Sefer ha-Hešeq, 42, where this term is again connected with a mental operation. In Gan Na'ul, 40, Abulafia speaks about the “operation of prophecy” (פועל הנבואה). 
Here lies the peak of Abulafia's axiology of religious life: the inner transformation is conducive to a state of universalisation, which means the transcendence of the normal human type of existence. We may no doubt discern some form of tension between the spiritualisation of the personal life that gravitates around an internal process which at the same time culminates in an experience of adherence to or union with an objective world that is quintessential for the act of transformation. Whether this implies an individual type of survival for the intellect or not-as is the case for Averroes-is not clear in Abulafia's thought, since transformation into another species may imply a loss of the older individuality.

In this specific case, we may assume that the description of universalisation is also reminiscent of the famous account of the ascent in Plotinus's Enneads, where the ascending soul is looking down at what is beneath her. ${ }^{294}$ Such a view was circulating in Arabic sources in the so-called Theology of Aristotle and had a significant impact on Jewish philosophers and Kabbalists, ${ }^{295}$ though it only became known to Abulafia's school later on. ${ }^{296}$ It should be mentioned that although universalisation is described here as being inclusive of the lower species and thus it may be depicted as more complex, according to Abulafia's description of the highest sphere that encompasses the lower ones, that sphere is "more simple" than the lower. ${ }^{297}$

In any case, Abulafia's description above is reminiscent of the manner in which he describes the nature of the first entity or substance, seen as God qua Necessary Existent:

It is necessary that a first substance ${ }^{298}$ is separated from all the aspects, ${ }^{299}$ comprising beneath it all the mentioned principles that are substantial, and that it includes the accidents that have no existence outside the substances, and in the similarity of the particulars of the universals, the

294 Enneads 4.8.1. On ecstasy in Plotinus as a super-intellectual and sudden experience, see Émile Brehier, The Philosophy of Plotinus, trans. Joseph Thomas (Chicago: Chicago University Press, 1958), 147-63; Anna Kelessidou-Galanou, "L'extase plotinienne et la problématique de la personne humaine," Revue des Etudes Grecques 84 (1971): 384-96; and Gregory Shaw, Theurgy and the Soul: The Neoplatonism of Iamblichus (University Park: Pennsylvania State University Press, 1995), 232-36. 295 Cf. the Hebrew translation included in Rabbi Shem Tov Falaquera, Sefer ha-Ma'alot, ed. Ludwig Venetianer (Berlin: S. Calvary, 1894), 22. See also Scholem, On the Mystical Shape, 257-58; Scholem, Major Trends in Jewish Mysticism, 203; and Idel, Messianic Mystics, 52. On the impact of this work on thirteenth-century Jewish thought, see Altmann, "The Delphic Maxim," 26-28; Alexander Altmann and Samuel Stern, eds. and trans., Isaac Israeli: A Neoplatonic Philosopher of the Tenth Century (Oxford: Oxford University Press, 1958), 191-92; Paul B. Fenton (Ynnon), "Shem Tov ibn Falaquera and the Theology of Aristotle” [Hebrew], Da'at 29 (1992): 27-40; and Afterman, Devequt: Mystical Intimacy, 40-41. See also Kreisel, Prophecy, 626-27, and note 13.

296 See Rabbi Judah Alboțini, Sullam ha-'Aliyyah, 73, trans. in Idel, Ascensions on High, 51-52.

297 Oșar 'Eden Ganuz, 1:3, 139: העליון המקיף מעולה מן המוקף ופשוט ממנו

298 Compare the resort to the description of God as "one substance" in his commentary on Sefer ha'Edut, 60, discussed in Appendix C below.

299 Namely, from everything else. 
species of the genera and their principles would [exist], [and so] all existing things are beneath the first thing. ${ }^{300}$

This is a quasi-Spinozistic presentation of ontology that combines the concept of utmost simplicity with compoundness; a combination which Abulafia considers to be one of the greatest secrets. ${ }^{301}$ The "first thing" is a substance, a view that does not fit the Aristotelian ontology, but perhaps a more Neo-Platonic one, and all the lower beings are gradually determined by categories of genus, species, and accident, each more limited than the previous. This "downward" movement of limitation has an opposite process of an upward movement that removes the limitations from the particular beings that are capable of elevation. I see here an affinity between this passage and the description of the transformed self in the passage from Oșar 'Eden Ganuz presented earlier in this chapter.

In any case, the last quoted passage from Oșar 'Eden Ganuz contributes a better understanding of the passage from Or ha-Śekhel about each individual containing all the members of his species. I would consider it a description belonging to the second narrative whose secret meaning, belonging to the third narrative, is offered in the passage we have just translated that deals with the individual intellect that is integrated into the more comprehensive entities.

Abulafia's views discussed here should be compared to Averroes's approach to intellection, which has been cogently summarised in a recent study as follows:

The individual intellect loses its individuality through becoming immersed in a realm of universal concepts. When we are at the level of using imaginative representations, those representations very much belong to a particular individual, and they represent aspects of the material side of the agent intellect. Once there is progress to more and more abstract thinking, these more graphic forms are put behind the individual thinker and immersion and conjunction occurs with the agent intellect itself. As human minds become more and more perfect, they become less and less human and individual. They free themselves gradually of the material body and its accompanying ideas, and become much more like the agent intellect. They lose in specificity and gain in generality, and any normal sense of person disintegrates totally. ${ }^{302}$

300 Commentary on Sefer Yeșirah, 20:

והתחייב מזה היות עצם ראשון נבדל בכל צד מהצדדים כולל תחתיו כל הכללים הנזכרים שהם עצמיים וכל שכן המקרים

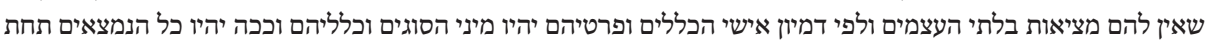

הדבר הראשון.

As Weinstock proposed in his footnotes, it seems that there is here an impact of ibn Ezra's theory of All, mentioned in chapter 7 note 278 and chapter 21 note 292 above; as well as that of ibn Gabirol. See also Appendix E note 13 below. Harald A.I. Reiche, Empedocles' Mixture, Eudoxan Astronomy and Aristotle's Connate Pneuma (Amsterdam: Hakkert, 1960), 101-32, discusses the concept of "General because First."

301 See the untitled short treatise found in Ms. Sassoon 290, 235.

302 Oliver Leaman, Averroes and His Philosophy, rev. ed. (Surrey: Curzon Press, 1998), 90. See also Rabbi Hasdai Crescas's interpretation of Maimonides, as found in Warren Zev Harvey, "Hasdai Crescas' Critique of the Theory of the Acquired Intellect” (PhD diss., Columbia University, 1973), 125. Cf. Crescas's text on 278 (English, 432). 
Despite changes in Averroes's own views over the years as to the status of the material intellect and the nature of the acts of intellection, as has duly been pointed out by scholars, ${ }^{303}$ Leaman's description fits many of the less systematic and fragmentary treatments of those topics in Abulafia's writings. It should be mentioned that Abulafia's imagery of the expansion of the mind-namely, its becoming wider and wider when interpreting the Bible by means of several exegetical methods-is paralleled by his image of the seven paths, the seven concentric spheres, the highest being the most comprehensive and corresponding to the most sublime form of exegesis, while the first or the lowest of these spheres is the most limited of them, dealing with the plain sense. ${ }^{304}$

In a work written in a similar vein to Abulafia's Kabbalah, we read that "the power of speech is called the rational soul, which received the divine influx, called Knesset Yiśra'el, whose secret is the Agent Intellect, which is also the universal influx, ${ }^{305}$ and which is the mother of the intellect of the world." ${ }^{306}$ Though not com-

303 See Davidson, Alfarabi, Avicenna, and Averroes on Intellect; Arthur Hyman, "Averroes' Theory of the Intellect and the Ancient Commentators," in Averroes and the Aristotelian Tradition, 188-98; Alfred L. Ivry, "Averroes' Three Commentaries on De Anima," in Averroes and the Aristotelian Tradition, 199-216; Alfred L. Ivry, "Averroes on Intellection and Conjunction," JAOS 86 (1966): 76-85; Richard C. Taylor, "Remarks on Cogitatio in Averroes' Commentarium Magnum in Aristotelis de Anima Libros," JAOS 86 (1966): 217-55; Kalman P. Bland's introduction to his edition of The Epistle on the Possibility of Conjunction with the Active Intellect by ibn Rushd with the Commentary of Moses Narboni (New York: Jewish Theological Seminary of America, 1982); Blaustein, "Averroes on the Imagination and the Intellect," 211-73; and Maurice Blaustein, “Averroès et Moïse de Narbonne: Sur la possibilité de la conjunction," Archives juives 21, no. 1-2 (1985): 5-9.

304 See Idel, Language, Torah, and Hermeneutics, 122-24.

305 השפע הכללי. The identification between the influx and the Agent Intellect should be understood as part of what I call a limited pantheistic approach that is visible in Abulafia's writings, but less evident in Jewish philosophy. See the discussion of the topic in Idel, Studies in Ecstatic Kabbalah, 1214. The fact that Abulafia repeatedly distinguishes between God and the influx and describes the former using the philosophical terms "Necessary Existent" and "Prime Mover" (see chapter 16 note 106 above) is the reason why I use the qualification of limited pantheism: immanentism. See Idel, Kabbalah in Italy, 147-48. See, on the other hand, Wolfson, "Kenotic Overflow and Temporal Transcendence," 169-70. Wolfson does not refer to these theological issues, but decides that pantheism is a better description of Abulafia's position than limited pantheism. However, without first presenting the entire range of pertinent materials, it is quite easy to claim new insights, or qualifications of older ones, which eventually turn out to be dramatically problematic when additional material is taken into consideration, and I refer here only to Abulafia's printed material. One may ask how this panentheistic approach operates together with the theosophical vision of the sefirot that Wolfson champions on other occasions. It is one more quandary that deserves elaboration. I am, therefore, more concerned with understanding the fluidity of Abulafia's thought, or of any other thinker, than to establish clear-cut theological positions deemed to represent what I assume is a complex discussion. See also my "Deus sive Natura," 185-86.

306 Sefer Or ha-Menorah, Ms. Jerusalem, $8^{0}$ 1303, fol. 28b. For details on this book, see Idel, "Abraham Abulafia's Works and Doctrine," 79. On the term Knesset Yiśra'el in similar contexts, see Idel, Studies in Ecstatic Kabbalah, 80, and the pertinent footnotes; Idel, The Mystical Experience, 211-12, note 36; and Ben, 321, 332. Compare, however, what Wolfson attributes to me, based on some of 
pletely identical to Abulafia's passage, the terminology is nevertheless quite similar. Here, universality is explicitly regarded as being related to a higher ontological level, and similarly, we see the concern with the move towards language (the power of speech) which, unlike the view found in Aristotle's Politics that was adopted by many thinkers, defines the human being by his capacity of intellection. ${ }^{307}$ Interestingly enough, the secret is presented as the inner sense of the traditionally Jewish theme, which is the philosophical concept of the Agent Intellect.

In one case, found in Rabbi Nathan ben Sa'adyah's treatise Ša'arei Ṣedeq, Moses is described in terms quite similar to Abulafia's treatment of Moses elsewhere in Sitrei Torah $^{308}$ as having "been transformed into a universal [being] after being a particular, central point. And this is the matter of the lower man who ascended and became "the man who is upon the throne, ${ }^{309}$ by virtue of the power of the Name." ${ }^{10}$ This de-

my other discussions, in “Kenotic Overflow and Temporal Transcendence," 173, note 159, as if he gives a somewhat different reading from mine! As to his suggestion there that the appellative Malkhut for the Agent Intellect should be attributed to theosophical Kabbalah, see the text from the Hebrew translation of Al-Fārābỉ's book Hathalot ha-Nimṣa'ot, which is paraphrased by Abulafia in his Sitrei Torah, translated and discussed in Idel, Ben, 279, 352-53, note 70, and in Idel, "Definitions of Prophecy: Maimonides and Abulafia," 6, 11-13. In this passage, Abulafia, following Al-Fārābī, designates the Agent Intellect as Malkhut ha-Šamayyim ("the dominion of heaven"). This is an interesting example that shows how a better acquaintance with the philosophical background of both the ecstatic Kabbalist and the scholarly bibliography on the matter under discussion dramatically mitigates the theosophical reading of Abulafia.

307 An issue that is central for Abulafia is the speech that a person may have with the imaginary representation of the Agent Intellect in the form of the aspirant, as found in a variety of texts. See my The Mystical Experiences, 86-95, and Mafteah ha-Hokhmot, 60. This speech may have two meanings: an intellectual one (a communication of ideas without any linguistic components) and an imaginative one (self-revelation and linguistic communication). Interestingly enough, the former is conceived as philosophical, while the second is conceived as Kabbalistic.

308 Idel, "Universalization and Integration," 30. See also Idel, Language, Torah, and Hermeneutics, 106. It should be pointed out that Abulafia does not conceive all types of prophecy as leading to an experience of universalisation. See his Šomer Mișwah, 5-6.

309 Ezekiel 1:26. It should be noted that this verse is the proof-text for the Midrashic dictum about the prophets who compare forms to the entity that forms them, which is presented by Rabbi Nathan by means of a passage quoted from a book by Rabbi Isaac of Acre, as cited by Rabbi Moses of Kiev, to be discussed below in Appendix B note 82. On the concept of "the point," which in Abulafia's writings refers either to the Agent Intellect or to the human soul, see Idel, Language, Torah, and Hermeneutics, 40-41.

310 Nathan ben Sa'adyah Ḥar'ar, Le Porte della Giustizia, 385:

וזהו ענין משה שב כללי אחר היותו נקודה פרטית מרכזית וזהו ענין האדם התחתון שנתעלה ונעשה אדם שעל הכסא בכח

הש'. רוזי

Compare to Abulafia's Commentary on Sefer Yeșirah, 24. Warren Zev Harvey indicated to me the similarity of this view to that of ibn Kaspi, which is found in his commentary on the Guide in 1:14, 30 . Compare this to the manner in which Sagerman (The Serpent Kills, 320, note 207) interprets the term "all" in the context of Moses as suggestive of the sefirah Yesod. See also Sagerman, The Serpent Kills, 166. This is an interesting example of the vicissitudes of the application of Freudian interpreta- 
scription is closer to Neo-Platonically oriented transformations of the particular soul into the universal soul, a phenomenon I propose to call universalisation. ${ }^{311}$

This form of expression, which may or may not represent an experience that is different from others and which is described as involving cleaving to God and a mystical union, already had a history in Jewish mysticism. Rabbi Nathan's Ša 'arei Ședeq is just one link in a longer chain of traditions. Indeed, some lines further on, our author explicitly refers to the "soul of all." 312 In this brand of Kabbalah, Moses's transformation should be understood as being accomplished by means of a name (hašem) which consists of the same consonants as Mošeh, a term that stands for the Tetragrammaton, though its consonants have been permuted. Therefore, by resorting to the Kabbalistic technique based on names used by Abulafia, Moses is imagined as becoming a supernal man.

The transformation from the particular to the general is found elsewhere, in a book written by Rabbi Isaac ben Samuel of Acre, a disciple of Rabbi Nathan, the author of $\check{S}$ ' arei Ședeq. This more famous Kabbalist mentions "the Nought, which encompasses everything" 313 and elsewhere writes that "the soul should cleave to Nought and become universal and comprehensive after being particular because of her palace ${ }^{314}$ when she was imprisoned in it; [she] will become universal, in the secret of the essence of the secret of her place from which she was hewn." 315 Interestingly enough, Rabbi Isaac of Acre is one of the few Kabbalists who uses the expression "universal Kabbalah." 316 Like Rabbi Nathan, he is also concerned with the NeoPlatonic sort of universalisation concerning the soul and much less with the Neo-Aristotelian one concerning the intellect. In any case, the transformation of the intellect is part of a wider scheme that denies changes in the separate supernal intellects, at

tions to medieval texts whose agendas are quite different. For the special relationship between the "distinguished man" and the "unique name" of God, see Hayyei ha-Nefeš, 128.

311 For more on the concept of universalisation in Abulafia and its sources, see Idel, "Universalization and Integration," 28-33, and Appendix E.

312 Nathan ben Sa'adyah Har'ar, Le Porte della Giustizia, 385: נפש הכל.

313 I hope to deal with this view in a separate study.

314 "Her palace" is Heikhalah. The latter is a recurrent image in Rabbi Isaac's writings on the body. See also the quote from an unnamed Kabbalist found in Rabbi Nathan ben Sa'adyah, Ša 'arei Ṣedeq, in Le Porte della Giustizia, 373, and in the Hebrew translation, attributed to Maimonides, of the anonymous Peraqim be-Hașlahah, ed. David Baneth (Jerusalem: Mekize Nirdamim, 1939), 17. Here, the term "comprehensive," in the sense of "embracing or encompassing the lower", reflects Neo-Platonic terminology.

315 Sefer Oșar Hayyim, Ms. Moscow, Günzburg 775, fol. 233b. I have translated the rather exceptional formulation found in this version, which uses "Nought" in lieu of Ein Sof, as is also the case in the version of this passage in Ms. Oxford, Bodleian 1911, fol. 154b. "Nought" is wa-tidbaq nefeš zo be-ayin. 316 See Sefer Oșar Hayyim, Ms. Moscow, Günzburg 775, fol. 93a:קבלה כללית. On this topic, also found in both the school of Rabbi David ben Judah he-Hasid and in Abulafia, I hope to elaborate elsewhere. 
least in the various speculative corpora that nourished the diverse thought of these Kabbalists. ${ }^{317}$

Given the centrality of the process of universalisation in these texts and many others that cannot be adduced within this framework, I propose to see them in the wider context of the concepts of the universal speech and the universal religion, both in the past and in the future. I would read the content of passage [a1], dealing with the distancing from the universal religion, as something negative that is complemented by the universalisation of the intellect. In other words, they are two complementary movements reminiscent of the Neo-Platonic procession and regression. The human intellect, when purified of imaginative contents, turns universal, reaching a form of prophecy or a state that parallels the universal religion. These vertical motions are paramountly transhistorial and individual, not national or historical. The Moses who gave the Torah is not necessarily a historical figure, and nor is the high priest, as we shall see in chapter 24; these are examples of the "perfect man" who became universal.

According to one of Maimonides's views, among all the prophets, only Moses did not use imagination in his prophecy. Abulafia would say that this disappearance of imagination is essentially a cognitive event, not a historical one, as we shall see below in chapter 22. In any case, unlike Maimonides, Abulafia thought that the Messiah would be higher than Moses, ${ }^{318}$ and given that he thought that he was the Messiah, the implications are obvious: he imagines that it would be possible to experience a revelation higher than the Mosaic one. What is quite central in Abulafia's Kabbalistic approach is the exegetical spiritualisation of the Hebrew Bible, of Rabbinic Judaism, and, in some cases, of concepts found in theosophical Kabbalah as if they are esoterically referring to inner processes that have salvific valences, and he offered alternative techniques designed to attain this goal. ${ }^{319}$

The process of noetic universalisation also seems to be the clue for understanding the meaning of the people's new attitude towards one another at the end of paragraph [c] as part of a more general category: the species. In the utopian situation, the individual person-in my opinion, an allegory for the intellect-loses his particular status and approaches all other people as though they are part of a more general and unified category, which as a whole will be in contact with the divine. In the eschaton, individuals belong to their species and nations are no longer mentioned.

The integration of individuals-again, I believe that this is an allegory for the intellect-into a more general entity, which he refers to as the human species, does not include the integration of their religions, which are no longer mentioned, but rather

317 See Mafteah ha-Ra'ayon, 5.

318 In Sitrei Torah, 11-12, Moses is portrayed as attaining the most perfect intellectual achievement possible for a man; see also Mafteah ha-Hokhmot, 105, and Hayyei ha-Nefeš, where he refers to Moses as prophesying without the faculty of imagination. See 157.

319 See Idel, “"The Time of the End,"” 155-86, and Wolfson, "Kenotic Overflow and Temporal Transcendence,” 177. 
involves a process of simplification, which means the spiritualisation of the essence of the individual persons; that is, the purification of the process of cognition from imaginative contents that are based on composed images. This is also a process of depersonalisation, to use Philip Merlan's term; it is a dissolution of individuality. ${ }^{320}$

This dissolution is the main reason why Abulafia here refers twice to the concept of the human species as a whole; the distinguished individual's spiritual or mental development has nothing to do with the specificity or uniqueness of his human existence. $^{321}$ This simplification and depersonalisation, related to an intensification of experience that has a profound intellectual significance, is the peak of Abulafia's Kabbalah and represents a phenomenon that differs from the more widespread cases of religious interiorisation that assume the existence of each individual's complex inner life. Nevertheless, such complexity is obvious in Abulafia's theory of inner struggle and prophecy, which are considered lower forms of his mystical path, but not in the higher ideal of mystical union.

In any case, let me emphasise that Abulafia's view of the human species as consisting solely of those individuals who have succeeded in actualising their intellect differs from modern understandings of humanism, which assume the importance of the compound of body and soul. It seems that we have here a version of the encounter of the one with the One: the more something ascends to the divine, the more unified it is. In this context, it seems that the necessity of language for inter-human communication is rather questionable: if people are conceived as the limbs of a great utopian organism that is constituted by the human species, then no one really speaks to his own limbs as they operate through thought alone. ${ }^{322}$

320 Philip Merlan, Monopsychism, Mysticism, Metaconsciousness: Problems of the Soul in the Neoaristotelian and Neoplatonic Tradition (The Hague: Springer, 1963), 84. On dissolution, see Walter T. Stace, Mysticism and Philosophy (Los Angeles: Tarcher, Inc., 1960), 111-23, especially the reference to Abulafia on 116. According to Stace's criteria, Abulafia is an introverted mystic. I see no reason to assume that by the human turning divine, there is also an implication that the divine thereby becomes human, as Wolfson assumes (Abraham Abulafia, 148) as part of his Christotropic understanding of Abulafia's thought.

321 See the use of the phrase מין האדם in dozen of instances in Abulafia's writings, as well as in "Ševa' Netivot ha-Torah," 4.

322 The metaphor of a human organism that organises more complex particulars occurs in several instances in Abulafia's writings. See also Averroes in van den Bergh, The Incoherence of Incoherence, 253-54. For the resort to the metaphor of the organism in general, see Judith E. Schlanger, Les métaphores de l'organisme (Paris: Vrin, 1971). This a-linguistic, intellectual type of communication is reminiscent of the scholastic question as to how angels communicate. See Theo Kobusch, "The Language of Angels: On the Subjectivity and Intersubjectivity of Pure Spirits," in Angels in Medieval Philosophical Inquiry: Their Function and Significance, eds. Isabel Iribarren and Martin Lenz (Aldershot: Ashgate, 2008): 131-42; Barbara Faes de Mottoni, "Enuntiatores divini silentii: Tommaso d'Aquino e il linguaggio degli angeli," Medioevo 12 (1986): 199-228; Bernd Roling, Locutio Angelica: Die Diskussion der Engelsprache als Antizipation Einer Sprechakttheorie in Mittelalter und Früher Neuzeit (Leiden: Brill, 2008); Bernd Roling, "Angelic Language and Communication," in A Companion to Angels in Medieval Philosophy ed. Tobias Hoffman (Leiden: Brill, 2012): 223-60. 
If this is the case, the perfect language is not to be found in the Jewish nation in the present, given its precarious plight in its exile; in the future, when the pearl returns to the son in accordance with the national narrative, it will become superfluous. Will the sublimation of the spoken languages, or the historical ones, take place by ascending to the intellectual form of activity, in a manner reminiscent of Maimonides's approach to mental prayer? Is such sublimation connected to the effacement of imagination that will be mentioned in one of the passages from $\mathrm{Or}$ ha-Śekhel) ${ }^{323}$ Those processes may take place in the present, at least for the perfect individual.

To formulate the quandary in different terms: if, in the exilic situation, there is hope that the son will receive the pearl, perhaps consisting in the three virtues, as distinct from the status of the servants, he will not receive them in the eschaton while he is still a separate entity, an individual. This reception will only be possible as part of the unification of the entire human species, not as a separate part, not as a particular, not as a separate nation, important as it may be, distinct from the other nations which keep their particular nature even in the new situation. Or, to put it in more epistemological terms, only by becoming universal can the individual be saved.

In my opinion, the cessation of the antagonism between people or nations that is part of the historical narrative is explained as the result of the disappearance of the imaginative power. The species is, naturally, a much more comprehensive category than the nation. Abulafia's specific emphasis on the individual can be discerned if we compare the content of the biblical verses he uses as a proof-text to his own words: while the biblical verse speaks of the nations, at the end of paragraph [c], Abulafia speaks of the individuals: the "members of the species."

Thus, in my opinion, the historical redemption includes a transcendence of the present divisions between religions and nations. Indeed, what seems to be the major distinction with which Abulafia is operating is much less the widespread dichotomy between Jews and Gentiles, as some of the other Kabbalists were assuming, but the dichotomy between elite persons or distinguished individuals and the multitude found in different nations, including in the Jewish nation.

When dealing with the threefold distinction between exegetical techniques, he sees in the first, the "vulgar one," dealing with the plain sense, an approach that

it is appropriate to safeguard [the vulgar sense] together [with two other senses for the sake of] the vulgus, who are the righteous in the nation, [...] that it is appropriate to safeguard the three ways since all three are true, but there are three different degrees and each of them perfects what is appropriate in order to perfect those [individuals] who safeguard it and know it. And there is no doubt that among the Christians, there are some sages who know this secret, and they spoke with me secretly and revealed to me that this is their position, indubitably. And I considered them to be in the category of the pious men of the Gentiles. ${ }^{324}$ And one should not care as to

323 The passages are translated above pp. 148-49.

324 "The pious men of the Gentiles" is a Rabbinic category, which, from a linguistic point of view, is problematic for Abulafia's conceptualisation, since in his books, "pious" stands for a lower category. 
the words of the fools in any nation, since the Torah was not given but to those who possess knowledge. ${ }^{325}$

This dichotomy seems to me to reflect an Averroistic approach, although the distinction involves a threefold rather than a double-truth theory. In the vein of the interpretation of the parable about the mindless son who does not initially receive the pearl, the Torah is here conceived as being given only to those who possess knowledge, a far-reaching statement that assumes that the Torah has only been revealed to the elites, be they Jewish or not. ${ }^{326}$

The first part of the passage is much more harmonistic, while the end is much more exclusive or disjunctive; just one more example of Abulafia's conceptual fluidity. As to the possible identity of the Christian interlocutors that the Kabbalist mentions, let me propose an alternative to the hypothesis suggested by Gershom Scholem, who speaks about contacts with Christian mystics, ${ }^{327}$ and Harvey Hames, who claims that they are "perhaps [...] Franciscan Joachimists." ${ }^{328}$ Although this sugges-

See also Wolfson, “Textual Flesh, Incarnation, and the Imaginal Body," 207, note 76. For the more universalist Rabbinic approach, see Michael Zevi Nehorai, "Righteous Gentiles Have a Share in the World to Come" [Hebrew], Tarbiz 61 (1992): 465-87. For the existence of earlier missionary vectors in Rabbinic Judaism that have been eradicated, see Moshe Lavee, "Converting the Missionary Image of Abraham: Rabbinic Traditions Migrating from the Land of Israel to Babylon," in Abraham, the Nations, and the Hagarites: Jewish, Christian, and Islamic Perspectives on Kinship with Abraham, eds. Martin Goodman, George H. van Kooten, and Jacques T.A.G.M. van Ruiten (Leiden: Brill, 2010): 203-22.

325 Introduction to Mafteah ha-Hokhmot, 48-49:

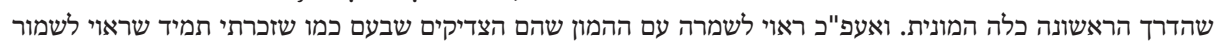

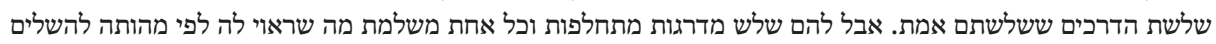

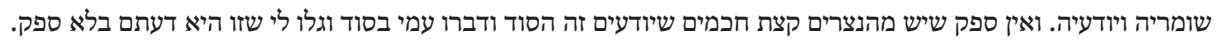
ואז דנתים אני גם כן מכלל חסידי אומות העולם. ואין לחוש על דברי הפתאים בשום ודברו עומה שסוד שלא נתנה תורה אלא לבעלי הדעת.

See Scholem, Major Trends in Jewish Mysticism, 129, 379, note 33. On triple exegetical and anthropological hierarchies, see Idel, Language, Torah, and Hermeneutics, 109-14. The anthropological distinction between the common people (the multitude), the philosophers, and the prophets is a recurring theme in Abulafia's writings; it may reflect an earlier source for the similar position of Rabbi Shem Tov ibn Falaquera in Sefer ha-Ma'alot, 77, as well as ibn Kaspi. See Mesch, Studies in Joseph ibn Caspi, 86. On the ironic phrase "our sages, the fools of the Jews, [...] the majority of the sages of our generation are fools,” see Abulafia's early work Sefer Ge'ulah, 45: [...] ויאיר לבות חכמינו הפתאים היהודים .רוב חכמי דורנו פתאים. Thus, even the sages who fall under the second part of the triple anthropology are conceived to be foolish Jews.

326 See the intellectual interpretation of the Rabbinic statement that the Torah was only given to those who consumed manna in his Hayyei ha-Nefeš, 152.

327 Scholem, Major Trends in Jewish Mysticism, 129. Wolfson, "Textual Flesh, Incarnation, and the Imaginal Body," 197, note 31, correctly questions the accuracy of Scholem's assessment.

328 Hames, Like Angels on Jacob’s Ladder, 43, 127-28, note 59. See, however, his much more confident statement issued on page 2 of the introduction of this text: "Abulafia's works show that he was in constant dialogue with Christianity, or more precisely, with a mode of Christianity highly influenced by the thought of the twelfth-century Calabrian abbot, Joachim of Fiore.” This was indeed 
tion is indeed possible from the historical point of view, this identification is far from being certain. Even less certain is the following statement, which is not supported by any evidence, to the effect that it is possible to explain "why some of the Franciscans in Rome were so eager, less than one year later, to see what would happen when Abulafia met with Nicholas III." 329 Who those Franciscans were and where this statement came from is quite obscure and is perhaps the result of a theoretical imagining of what could have happened in history, something of which Hames is fond.

In my opinion, Abulafia's assumption regarding the topic of a consensus with those anonymous Christian sages mentioned in this passage is, quite evidently, much closer to an Averroistic approach than to the above-mentioned unidentified Christian spiritualists. Abulafia could have been acquainted with Christian circles whose thought was nourished by the Latin translations of the Cordovan commentator while in Italy in the 1260 s or the $1280 \mathrm{~s} .{ }^{330}$ In any case, the formal condemnations of Averroism in Paris in 1270, 1272, and again in 1277 by Bishop Etienne Tempier show that the perception that the Arab philosopher was a heretic had already spread among the Christian intellectuals long before 1289, when the passage quoted above was written, to say nothing of the earlier critique of Albertus Magnus. ${ }^{331}$

Thus, the attempt to claim that there is only one potential Christian context for Abulafia's thought, as Hames claims when pushing the Joachimite-Franciscan one, is problematic, for it is obvious that one must consider several contexts rather than a single one. ${ }^{332}$ The resort to the assumption of one context, as undertaken by so many

the issue to be proven, and it seems that at the end of the book, the author himself acknowledges the fact that no solid proof has been found. It should be mentioned that this hypothesis was adumbrated long ago by Jacob L. Teicher, following a discussion by Yitzhak Baer. See the former's "The Medieval Mind," JJS 6 (1955): 2. See also my "Abraham Abulafia and the Pope: The Meaning and the Metamorphosis of an Abortious Attempt” [Hebrew], AJS Review 7-8 (1982/83): 1-17; reprinted in my Chapters in Ecstatic Kabbalah [Hebrew] (Jerusalem: Akademon, 1990): 51-74, 69-70. Acquainted as I was with this hypothesis from Teicher's study, I formulated my view that Joachimite influences on Abulafia were marginal, if they existed at all; this view of mine served as the motto for his introduction (1). Since no conclusive evidence has been shown to disprove my view, I have not changed it since then. However, as I mention in Messianic Mystics, 56, when such evidence is brought forth, another picture of the development of Jewish eschatology may emerge. Let me point out that Hames's assumption in Like Angels on Jacob's Ladder, 99, that Abulafia had contact with the Franciscans prior to his attempt to meet the pope who could have facilitated the encounter is, for the time being, not corroborated by any historical evidence with which I am acquainted. See also Scholem, Major Trends in Jewish Mysticism, 392, note 97, and Appendix D.

329 Hames, Like Angels on Jacob's Ladder, 96.

330 See also Hames, 133, note 4.

331 See Bernardo Carlos Bazán, “On ‘First Averroism’ and Its Doctrinal Background,” in Of Scholars, Savants, and Their Texts, ed. Ruth Link-Salinger (New York: Peter Lang, 1989): 9-22, and John F. Wippel, "The Condemnation of 1270 and 1277 at Paris," Journal of Medieval and Renaissance Studies 7 (1977): 169-201.

332 Like Angels on Jacob's Ladder, 4. See also Sagerman's use of "Christian context" in The Serpent Kills, 25. Like Wolfson's Jewish "comportment" in the singular, Christians are presented as a unified entity with no variation. These scholars neglect Orthodox Christians, for example: indeed, Abulafia 
historians, is entirely mistaken when dealing with a protean and itinerant figure like Abulafia. I would say that the resort to the singular underestimates the diversified and dynamic situations that Abulafia encountered.

Let me point out that the fact that the above passage exists is worthy of additional reflection. One may doubt indeed whether such a testimony is of any historical value, given the fact that it is not corroborated by external evidence. This is a legitimate question, but I have not seen any scholar who has doubted it. However, in my opinion, what counts more than the historical event, whether it actually took place or not, is the fact that Abulafia wanted to project the image of a person who spoke with Christians even on issues that-Halakhically speaking-were forbidden. This confession allows a better understanding of his self-perception and the manner in which he wanted to be perceived.

In any case, insofar as our knowledge of the direct relations between Jewish and Christian scholars in Italy is concerned, it seems that they had to do with matters of philosophy, and perhaps are related more to interactions with members of the Dominican and Augustinian orders, ${ }^{333}$ although Abulafia was imprisoned in Rome by the Minorites, an extreme group of Franciscans, for two weeks. ${ }^{334}$ It should be pointed out that although the Dominican order was more opposed to Averroism, it was the Franciscan order that campaigned for the condemnation of the Averroists in Paris. If my conjecture as to the identity of those Christians as Averroists is indeed correct, and it is still a conjecture, though I nevertheless see it as a more plausible one on the grounds of its content, we may have a relatively early example of the views that are known as Latin Averroism found among Christian authors. This is, to be sure, an intellectual phenomenon that differs from that known among the Muslims and the Jews; namely, the Christians' reception of the Cordoban thinker as a heretic, a critique that began some years earlier with Albertus Magnus. ${ }^{335}$

In another of Abulafia's statements, he refers to a more universalistic approach when he compares those Jewish Kabbalists who do not examine their beliefs by resorting to philosophical arguments to "the mequbbalim of the other nations." ${ }^{336}$ This

lived in the Byzantine Empire for several years. They also neglect Abulafia's Averroistic context, which reflects an Islamicate intellectual milieu. The reification of the "context" to just one single conceptual framework is a completely non-historical approach, especially for an author as itinerant as Abulafia was.

333 See Joseph B. Sermoneta, "Moses ben Solomon of Salerno and Nicholaus of Giovinnazo on Maimonides's The Guide to the Perplexed" [Hebrew], Iyyun 2 (1970): 212-40. Caterina Rigo claims that he was not a Dominican. See her "Per un'identificazione del 'Sapiente Cristiano' Nicola da Giovinazzo, collaborator di Rabbi Mošeh ben Šlomoh da Salerno,” Archivum fratrum praedicatorum 69 (1999): 61146. On the other hand, Aegidius Romanus was well-known to Italian Jewish authors. See also Appendix D note 214 below.

334 See Abulafia's Commentary on Sefer ha-'Edut, printed in Mașref ha-Śekhel, 58.

335 See Wolfson, "Averroes's Lost Treatise on the Prime Mover," 371-401; Leaman, Averroes and His Philosophy, 163-78.

336 “We-Zot li-Yehudah,” 28. 
means that there is no significant difference between the fools of the various nations, just as there is no real difference between their elites, because they are various groups that belong to the human species. Those statements are unparalleled in all Kabbalistic literature in the thirteenth century and should be seriously taken into consideration when surveying the basic configurations of the different Kabbalists in that period.

I opt, therefore, for a more universalistic, esoteric, and spiritually oriented approach to the parable, in contradistinction to the more particularist and historically oriented understanding of this story and of Abulafia's Kabbalah in general offered by Elliot Wolfson, especially in his Venturing Beyond. ${ }^{337}$ Given the fact that he recently quite vehemently denied my claim, calling it "grossly misleading," since I presented him as adopting a particularist reading of Abulafia's thought, ${ }^{338}$ allow me to quote another of his statements that is pertinent to my depiction of his view:"339 "Even in passages where Abulafia ostensibly embraces the philosophical anthropology of Maimonides, careful scrutiny reveals that he reinterprets the latter in a manner that shows greater affinity with the particularism of the esoteric tradition ${ }^{340}$ than with the universalism of medieval rationalism." ${ }^{341}$ It is fascinating to watch the recurrent resort to the singular: just one "esoteric tradition," just one type of "universalism," just one "medieval rationalism." As pointed out above in chapters 4 to 7, Abulafia was exposed to many different sources rather early in his career, and let me stress, again, that it is historically erroneous to speak about one context.

Let the reader judge what is "grossly misleading": either Wolfson's view and my presentation thereof, or the way he has now depicted it. ${ }^{342}$ The resort to the violent phrase "grossly misleading" is very difficult to understand in scholarship in general, and especially in this case, as Wolfson expressed the very views I had attributed to him only a few years earlier. ${ }^{343}$ In any case, he "grossly misunderstands" his own

337 Venturing Beyond, 60-61, 64-67; also see chapter 21 note 262 above.

338 See his “Textual Flesh, Incarnation, and the Imaginal Body," 200, note 41. See also his claim of ethnic particularity in Abulafia in the same article (204-5), discussed in chapter 12 note 11 above, as well as his “Ontology, Alterity, and Ethics in Kabbalistic Anthropology,” Exemplaria 12 (2000): 135. His claim that he admitted a universalistic reading of Abulafia "especially" in his analysis of one of Abulafia's texts in his Language, Eros, Being, 203-4, is not supported by the discussion found in my copy of his book; instead, he conflates Abulafia's view of language with that of Rabbi Moses de Leon, who was indeed quite the particularistic Kabbalist. Given his selective and sometimes even inverting treatment of Abulafia's understanding of the Rabbinic myth of pollution, as we discussed in chapter 9 above, I hardly can understand his position.

339 See another quote to this effect from the Venturing Beyond, 65, note 203, that was discussed above in chapter 9 note 96.

340 Something that is not so clear to me is which exact "esoteric tradition" in the singular he has in mind. Was there only one esoteric tradition in Judaism? See note 467 above.

341 Venturing Beyond, 65.

342 This is just one more example of the art of inversion. See chapter 9 note 93 above.

343 In fact, this is not a surprising case for a careful reader of his vast opus. Concerning another topic, Wolfson has changed his mind twice in three consecutive years without alerting the reader. 
statements, which in the past I chose not to quote, but it seems that it is sorely necessary to remind him of his own views, which he has never recanted, including in his most recent studies, such as "Deceitful Truth, Truthful Deceit."

Meanwhile, something very positive has happened more recently in Wolfson's understanding of ecstatic Kabbalah, as he now confesses that in fact, "I do not deny the universal dimension of Abulafia's prophetic Kabbalah." ${ }^{344}$ However, only a few pages later, in the very same paper, he writes about Abulafia's "dualist tone" when dealing with his anthropology. ${ }^{345}$ Is his "non-denial" of universalism denied again, or was the non-denial a last-minute insertion that does not fit his basic approach in this same paper?

My assumption is that Abulafia, as analysed above, is more radically universalist than many of the Jewish philosophers, including the Maimonidean camp, not less, as Wolfson claims. His view is a telling example of a scholar's explicit attempt to avoid or at least to belittle the need to take seriously the very books Abulafia studied and admired as potential sources, as well as his own statements. Let me elaborate on its consequence: it ignores all the basic data about both Abulafia's intellectual career and the fabric of his extant writings, replete as they are with philosophical terminology. However, those are not the worst misunderstandings of this Kabbalist's thought.

In fact, what is of even greater importance for understanding Abulafia is the fact that in many cases, linguistic esotericism is philosophically reinterpreted as the highest form of understanding, thus putting the philosophical apparatus ahead of the linguistic one, as we have seen in some of the discussions above, especially when we discussed the median Torah. Union and prophecy were understood as prominently noetic processes. Though linguistic manipulations are capable of cleansing the mind and opening the purified consciousness to new insights, those insights consist in philosophical interpretations of the linguistic units. This is the reason why the philosophical sources are so essential both at the beginning of the path and at its end.

Let me mention in this context the testimony of Rabbi Nathan Har'ar: after he used the technique he studied with Abulafia, which culminated with a mystical experience, speeches emerged from his mouth that he described as "words of wisdom," which should be understood as having speculative valences. ${ }^{346}$ Thus, philosophical concepts do not dissipate in the higher moments of experience, but reappear in the moment of ecstasy as part of an acceleration or intensification of the noetic process-

See Idel, "On the Identity of the Authors of Two Ashkenazi Commentaries on the Poem ha-Aderet weha-Emunah,” 139, note 339.

344 Wolfson, “Textual Flesh, Incarnation, and the Imaginal Body,” 200, note 41. See a somewhat more nuanced view in his "Kenotic Overflow and Temporal Transcendence," 149, note 61.

345 "Textual Flesh, Incarnation, and the Imaginal Body," 215. On the ontic status of the Jews, which is based on an erroneous understanding of Abulafia's view, see Wolfson, Venturing Beyond, 73.

346 Le Porte della Giustizia, 478-79: נתחזק בי כח העיון [...] ראיתיה מדברת חכמות. 
es. ${ }^{347}$ Interestingly enough, the practice of drinking wine in order to solve a philosophical problem attributed to Avicenna in Rabbi Nathan's book illustrates my point. ${ }^{348}$

The basic difference between Wolfson's approach and mine in matters of understanding Abulafia's thought is not just a matter of his rather inverted interpretation of the message of this specific parable; rather, it is grounded in basic methodological matters on how to read this Kabbalist's writings generally. The particularist mode corresponds, roughly speaking, to the national-historical narrative; however, I assume the centrality of a two-tiered form of interpretation in many cases in Abulafia's hermeneutics, with the spiritual and esoteric level being higher. This means, for example, that the son, if described as the Jewish nation as a whole in accordance with the historical narrative, not only does not possess the pearl in the present, but will also not obtain the pearl in accordance with the presented picture of the nature of the end that discusses the collective human organism as a species.

Thus, Wolfson's assumption that the preservation of the "the particular ethnicity that can actualise the potentiality of human beings to become universal by receiving the intellectual overflow of the logos" ${ }^{349}$ deals with a special ethnicity (in fact, a corporeal feature, or what I call a genetic factor) is misleading, since Abulafia's assumption is that the Jews' propensity to contemplation is the result of a special form of social organisation that allows certain individuals specific time for contemplation, though not the entire Jewish nation, many of whose individuals are incapable of higher spiritual achievements. ${ }^{350}$ Thus, it is not a specific ethnic self-assertion that transpires from these treatments, but a form of philosophical religion that one community embraces more than others.

In any case, insofar as the topics of sonship or the Rabbinic passage on the pollution of Adam are concerned, Wolfson's brief discussion leaves out some of the most pertinent and explicit materials on the topic on the one hand and generates exaggerated visions of the nature of Kabbalah on the other. This scholarly neglect of so many salient texts which deal with the very core issue under scrutiny-namely, Abulafia's attitude towards the Gentiles-misinterprets the single source that has been quoted, and that only in part, thereafter generating a general homogeneous picture of Kabbalah as a whole. ${ }^{351}$

This is quite an unfortunate new development-or should I say retrogression-in the study of Kabbalah in general and of Abulafia's thought in particular. What is even

347 On the importance of acceleration in mystical experiences, see Moshe Idel, "Performance, Intensification and Experience in Jewish Mysticism,” Archaeus 13 (2009): 93-134.

348 Le Porte della Giustizia, 55-56.

349 Venturing Beyond, 73.

350 See the passage from Mafteah ha-Šemot, Ms. New York, JTS 843, fols. 52b-53a, and 26, cited above in chapter 9.

351 See Idel, "Sefer Yetzirah and Its Commentaries," 490-91, and 550, note 559. In this text, I outline my proposal for using the expression "the art of invention." 
more surprising is the fact that the quintessential role played by the philosophical aspects of Abulafia's discussions of this topic, which constitute much of what I called the third narrative or register, have been neglected in this context. An entire book devoted to this Kabbalist and Christianity does not distinguish between the two different registers he uses, as if Abulafia was solely concerned with the historical level or with an inter-religious dialogue. ${ }^{352}$ Concerned more with softening or tempering the borderline between the ecstatic Kabbalah and the theosophical-theurgical one, scholars writing recently have neglected the very foundation of Abulafia's thought, which is grounded in the concepts that are characteristic of the Maimonidean movement. ${ }^{353}$

Last but not least: Wolfson's approach is generally more concerned with the esotericism that he finds in the semiotic field of theosophical Kabbalah; that is, it is concerned with an understanding of Kabbalah as dealing with mysteries, with the problem of ineffability, and with questions related to the expression of the mystical experience. I am much more concerned here with forms of political esotericism that are conditioned by the existence of the vulgus. In my opinion, this latter form of esotericism is the main sort in Abulafia's writings, and one should pay attention to its philosophical sources both from the point of view of the principles-namely, the sociological-anthropological distinction-and from the exegetical point of view; namely, the sources of Abulafia's allegorisations.

In this context, some of the occurrences of the terms sod and seter should be taken much more seriously, as we have seen above, especially when they are accompanied by adjectives that are superlatives, such as [sod] muflag, ${ }^{354}$ [sod] gadol, [sod] mekhusseh, or combinations of them, ${ }^{355}$ since they point not only to numerical equivalences-that is, gematrias-but also to topics that the Kabbalist did not want to explicitly disclose but which are part of his esoteric thought. The gist of this type of esotericism is, however, not the Neo-Aristotelian conceptual apparatus per se, as found in many books translated from Arabic, but its relevance for the proper understanding of religious topics, which may contradict the dominant and popular perception of those topics. The wide resort to terms related to secrecy in Abulafia's writings should invite a more thoughtful approach to decoding his thought, with the assumption in

352 This is also the case in his discussion of the son as an intellectual entity. In addition to the passage from Sitrei Torah referenced above in chapter 21 note 322, also see Oșar 'Eden Ganuz, 1:1, 5; 2:7, 267; and 3:9, 347, where the firstborn son is explicitly interpreted as the human intellect, which should be rescued from the material forces. For a similar situation where Wolfson does not take into consideration Abulafia's explicit view that does not fit into his claim of particularism, see our discussions above in chapter 9 about the pollution of the Gentiles, as well as the references in Idel, "On the Secrets of Torah in Abraham Abulafia," 422, note 239; 425, 429.

353 See Sagerman, following Wolfson, The Serpent Kills, 7, note 12.

354 Abulafia is fond of this epithet, which, although it recurs in his writings, is rather absent in early Kabbalistic literature.

355 See Hayyei ha-Nefeš, 114; Sod Yerušalayyim, ed. Raphael Kohen (Jerusalem: Raphael Kohen, 2001), 16; as well as the anonymous Sefer ha-Ṣeruf, 11, where all of these adjectives are found together. 
mind that there is a secret context for some of his discussions that may disguise a more subversive approach in its relationship to traditional concepts.

Another narrative that should be taken much more seriously into consideration is one that progresses from the spoken languages to the universal language and from there to the source that generates that universal language, the cosmic intellect. Thus, the process of descent that is mentioned at the beginning of the passage and which introduces the parable, paragraph [a]-and the image of the pearl in the pit fits this picture-is reversed by the return of the pearl in its brilliance in paragraphs [b] and [c]. At any rate, at least in one case, it is obvious that the combination of letters is not a matter of the Hebrew language alone: it can be done in every language. ${ }^{356}$ This is also the case with the gematrias that Abulafia contrived with words which stem from a variety of languages. ${ }^{357}$

The inclusion of many languages without referring to the possible existence of a problem in doing so in this passage is one of the expressions of Abulafia's more universal approach, and it has no parallel in theory and practice among the Kabbalists active in Spain or Safed. The combination of Abulafia's emphasis on the noetic processes that are universal by their sources and nature and his intense resort to other languages in his linguistic games contributed to the unique character of his Kabbalah in comparison to those developments in other Kabbalistic literature. ${ }^{358}$ This is one of the reasons for Abulafia's impact on both the Jewish Kabbalah and the Christian Kabbalah in the Italian Renaissance.

\section{What is the Pearl?}

Historical religions began with the assumption that the fundamental religious event, the revelation, took place at their very beginning. The institutional revelation is conceived as being in need of interpretation, clarification, and eventually even expansion, but it is hardly ever conceived as replaceable or as already transcended. This is most evident in Maimonides's (exoteric?) approach, where Moses is conceived as the perfect figure and the Torah is consequently conceived as unchangeable. Its esoteric meanings might indeed be lost or obfuscated by the tribulations of the exile, but

356 Šomer Mișwah, 16.

357 See Idel, "Multilingual Gematrias in Abraham Abulafia," and, e.g., Oșar 'Eden Ganuz, 176-77. 358 Compare also to Abulafia's Sitrei Torah, 140, and the secondary literature assembled in Wolfson, "Textual Flesh, Incarnation, and the Imaginal Body," 198, note 35. Let me point out that the combination of the two elements shows that language games are not always in service of a particular extant community, as some post-modern authors think, since Ashkenazi authors who resorted to these linguistic games did not adopt Neo-Aristotelian noetics and vice versa. See Jacques Derrida, Of Grammatology, trans. Gayatri Chakravorty Spivak (Baltimore: Johns Hopkins University Press, 1974). Abulafia's combination was, as much as possible, intended to create a new community of distinguished individuals, not a homogenic genetic one. 
they may nevertheless be restored, though not exchanged, as Muslims claimed, or supplemented, as Christians did.

With Abulafia, however, it seems that the situation is somehow different. Assuming an ideal, perhaps utopian universal religion based on acts of intellection, in good Maimonidean terms, the Torah as a specific revelation to the Israelites and the Jews, which have been formulated in a specific language, is, by its nature, limited. In my opinion, in his Kabbalistic project, Abulafia wanted to demonstrate not the truth of traditional Judaism as it was understood by the Rabbis, especially contemporary ones, but the truth of his own special and diverging message that strove for a universal understanding of Judaism as a natural, intellectual, and thus universal type of religion.

In my opinion, this was the religion he wanted to discuss with the pope. ${ }^{359}$ The critique of Christianity therefore comes together with a dislocation of a strongly generational type of sonship in Judaism traditionally understood in Rabbinic Judaism as the single principle for defining Jewish identity. It is not the historical Judaism that will prevail in the future, Abulafia assumes, but-if at all-a new esoteric, spiritual version, which is dramatically influenced by Greek philosophy and gravitates around the revelation of the divine name, that may or will transcend the existing historical religions. Rabbinic Judaism as conventionally understood, just like the traditional forms of Christianity and Islam, will not be integrated into this utopian universal religion, but will be transcended by it, either in the experience of the individual in the present through their following of Abulafia's technique or through the collective unified human species as a whole in the future, if we accept the veracity of the nationalhistorical narrative in his thought.

The old-new religion, like the pearl, does not emerge in a specific historical moment in the future, but is coexistent with reality and may enter history at an appointed moment. The ethnic Jews indeed have the propensity to accept this spiritual intrusion into history more than others, as they are conceived as having some form of linguistic and thus intellectual preparation, but neither in the past nor in the present have they actually possessed the pearl, which is the sole patrimony of the "real" Jews, the prophets and the mystics. This is the reason why Abulafia is so critical of the Jewish masses and of Rabbis, especially those in his generation, as we have

359 See Idel, “Abraham Abulafia and the Pope.” See now the particularist claim regarding Abulafia's position in Daniel Boyarin, Judaism: The Genealogy of a Modern Notion (New Brunswick, NJ: Rutgers University Press, 2018), 85-87, based solely on a misquotation of the passage from Abulafia's Hebrew text that I cited in that article. However, in the quotation in his book, the critical term for Boyarin's thesis, כלל-which should be translated as "principle"-is mysteriously absent from the original Hebrew text that I cited and elaborated on at length, while the term יהדות is spelt היהדות. Most probably, he read a corrupted version of my article, otherwise unknown to me, and if this is indeed the case, I deeply apologise for inducing him into such a big error. In any case, he was not aware of the existence of concepts such as "universal religion” and "universal Torah" in Abulafia's writing, which we saw in chapters 12 and 14 above. But see a totally different view in Sefer ha-Melammed, p. 32. Abulafia uses phrases such as universal Kabbalah and universal prophecy. See Mafteah ha-Sefirot, p. 56. 
seen in some cases above. ${ }^{360}$ Jews have the potential to receive the ideal Torah, but have not yet received it despite the fact that they have the three degrees: a Torah, a language, and a script.

Moreover, the absence of the pearl in the present (i.e., in the exile), according to the second narrative related to the parable, reflects the status of the most concrete and practical aspects of Rabbinic Judaism: the performance of the commandments, a most crucial requirement in general Jewish religious life. It seems, therefore, quite obvious that although commandments are described as being strictly necessary for the well-being of society and as having a political purpose, this is not necessarily the case for the utopian religion based on the priority of noetic processes. ${ }^{361}$ In other words, commandments are not identified with the pearl, but, perhaps, with the esoteric interpretations a Kabbalist like Abulafia can offer.

The question may be asked: what is the pearl, after all? ${ }^{362}$ My assumption is that just as Hebrew, in Abulafia's thought, is not the specific Hebrew language in its historical manifestations, but the basic principles that govern all languages, like the basic consonants and the principle of the combination of letters, ${ }^{363}$ likewise, religion or Torah is not a specific manifestation in history, but a more abstract or general principle, in the vein of the "universal religion" mentioned in chapter 14 above. Indeed, in many passages, Abulafia refers to the name 'HWY as the hidden name of God, which was concealed from or perhaps unknown even to Moses. Those consonants are also conceived as half-vowels and are described in several of Abulafia's texts, and before him in books on Hebrew grammar, as hidden letters, as they are not pronounced even when they are written in the regular spelling of the words.

These four letters are understood in our context as the letters of occultation: otiyyot ha-ha'alamah or otiyyot ha-seter. ${ }^{364}$ This name is also understood to be hinted

360 See also Abulafia's early book Mafteah ha-Ra'ayon, 23-24, 45; Idel, "On the Secrets of the Torah in Abraham Abulafia," 423-24; Idel, Language, Torah, and Hermeneutics, 74-75, and 184, note 203; and also the passage translated in chapter 20 note 229 above.

361 Compare to the much more positive attitude towards commandments in Gikatilla's early writings, discussed in Hartley Lachter, "Kabbalah, Philosophy and the Jewish-Christian Debate: Reconsidering the Early Works of Joseph Gikatilla," JJTP 16 (2008): 1-58.

362 For the resort to the pearl in a similar parable, see Pines, "The Jewish Christians of the Early Centuries of Christianity according to a New Source," 273-74 note 139; Idel, Studies in Ecstatic Kabbalah, 57, note 20; and Shagrir, "The Parable of the Three Rings," 167-68, and now in her Hebrew book The Parable of the Three Rings, 13-23. See also Roberto Celada Ballanti, La parabola dei tre anelli. Migrazioni e metamorfosi di un racconto tra Oriente e Occidente (Rome: Storia e literatura, 2017). 363 See Idel, Language, Torah, and Hermeneutics, 22-24.

364 See Scholem, The Kabbalah of Sefer ha-Temunah, 175-76; the Abulafian texts found in Hotam ha-Hafțarah; Mașref la-Śekhel, 117; and the discussion found in the untitled treatise in Ms. Firenze, Laurenziana, Plut. II, 48, fol. 70a:

וזהו צורף אותיות אהו"י ששם השם המיוחד בהם והם כנגד כל התורה כלה ואין דבור בלעדיהם והם אותיות הסתר לבדם והם ראש ואמצע וסוף. 
at in the consonants of the two divine names $\mathrm{YHWH}$ and ' $\mathrm{eHeYeH},{ }^{365}$ which are understood as hiding the real nature of the supreme divine name, a rather interesting case of esotericism. In my opinion, the special acoustic nature of these semi-consonants should be seen as the reason for their special status, much more than their numerical value or their written form. Abulafia seems to envision a form of vibration that is specific to those four letters. ${ }^{366}$

What is important is the fact that this specific divine name plays an especially important role in Or ha-Śekhel. ${ }^{367}$ The underlying assumption is that just as God revealed a new name, 'eHeYeH, to Moses in the context of his redemptive mission, so also the Messiah, who in this case is most probably Abulafia himself, will be taught a new name. In a way, this name is the most refined part of language, consisting of a word that is entirely compounded of vowels, the closest possible thing to a sublimation of the linguistic process. In one passage, Abulafia claims that the name that is

"This is the combination of the letters 'HWY, that He put the special name of God in them, and they correspond to the entire Torah and there is no speech without them, and they alone are the letters of occultation and they are the head, the middle, and the end."

This name is hinted at in Rabbi Judah ha-Levi, Kuzari, 4:3; Rabbi Abraham ibn Ezra's commentary on Exodus 3:8, and in his other books such as Sefer ha-Šem, chapter 3, and Sefer ha-Șahut. See also the introduction to Rabbi Abraham ibn Ezra: Yesod Mora' we-sod Torah, 52-54. These figures influenced Abulafia's discussion in Mafteah ha-Ra'ayon, 64, as well as Rabbi Azriel of Gerona, in Gershom Scholem, "New Remnants from Rabbi Azriel of Gerona's Writings" [Hebrew], in A. Klein and S. Gulak Memory Volume (Jerusalem, 1942): 218-19; Ibn Lațif, Șurat ha-'Olam, in Yossi Esudri, "Studies in the Philosophy of Rabbi Isaac ibn Lațif, Profile, Knowledge and Prophecy, and a Critical Edition of Șurat ha'Olam” [Hebrew] (PhD diss., Hebrew University, 2008), 2, 8, 25; and Rabbi Baruch Togarmi, Commentary on Sefer Yeșirah, in Scholem, The Kabbalah of Sefer ha-Temunah, 234. This name also plays a conspicuous role in Gikatilla's Ginnat Egoz, 340, 343-45, but not in his later theosophical writings. This shift is just one of the major developments in his Kabbalistic thought and shows how bizarre the assumption of the hidden name was in the eyes of theosophical Kabbalists. See chapter 17 note 132, chapter 22 note 383, and below chapter 25 note 45. For the grammatical status of these letters, see the anonymous grammar book Sefer ha-Binyan, Ms. New York, JTS 2325, 161. It is possible to see the impact of this view on an anonymous Kabbalistic treatise found in several manuscripts belonging to the circle of Sefer ha-Temunah, Ms. Vatican, 290, fol. 79a. I hope to deal with this text elsewhere. These letters, as discussed in Gikatilla's Ginnat Egoz, had an impact on other Kabbalistic writings like the early fourteenth-century Rabbi Hananel ben Abraham Esquira's Sefer Yesod 'Olam, Ms. Moscow, Günzburg 607, fol. 77a.

365 See Idel, The Mystical Experience, 140-41, and Idel, "Sefer Yetzirah and Its Commentaries," 513, note 270; 522, note 327. See also Wolfson, "Kenotic Overflow and Temporal Transcendence," 180. 366 See Guy L. Beck, Sonic Theology: Hinduism and Sacred Sound (Delhi: Motilal Banarsidass Publ., 1995); André Padoux, Vac: The Concept of the Word in Selected Hindu Tantras, trans. Jacques Gontier (Albany, NY: SUNY Press, 1990); Mark S. G. Dyczkowski, The Doctrine of Vibration: An Analysis of the Doctrines and Practices of Kashmir Shaivism (Albany, NY: SUNY Press, 1987).

367 See Or ha-Śekhel, 47, 48, 70, 77, and 85. See also the passage from the introduction to this book (3), which will be translated in the next chapter, and Oșar 'Eden Ganuz, 3:9, 346-47, where these four letters are described as the elements of "all speech," presumably a parallel to the concept of universal speech discussed above reflecting a phrase stemming from Sefer Yeșirah, 2:8. 
found with the Messiah "naturally" produces speech. ${ }^{368}$ In any case, the mystical technique found in Or ha-Śekhel is based on the combination of the letters of the Hebrew alphabet with the letters of the Tetragrammaton, found in several tables that illustrate the technique, presumably some form of elevating the ordinary letters by their conjunction with the semi-vowels that are components of the Tetragrammaton as well as by pronouncing them together. ${ }^{369}$

This combination of regular consonants with the letters of the Tetragrammaton also occurs in other instances in ecstatic Kabbalah. In an interesting discussion in Or ha-Śekhel, Abulafia emphasises that the letters of the divine name were added to the names of the forefathers and to Saray, ${ }^{370}$ and he invents theophoric names for his students. ${ }^{371}$ Even more so, this practice was also adopted by Rabbi Nathan, who hints at his first name by inserting it among the letters of the Tetragrammaton, YNHTWNH, as well as among the letters of ŠD (Šed, demon), NŠTDN. ${ }^{372}$ The intellectual fusion of the human and the divine is thus represented by a linguistic fusion. In any case, Abulafia conceives the knowledge of the divine name as the time of freedom and redemption, ${ }^{373}$ and in an interesting discussion, he claims that a person who strives to attain prophecy is called by a series of divine names, including the Tetragrammaton, Elohim, Adonai Elohim, the angel of Elohim, etc. ${ }^{374}$ From this context, it seems that these different names are connected to Abulafia's mention of the different degrees of progress in prophecy.

In a way, it is possible that the four letters conceived as a tetragrammaton are the first type of revelation that precedes the universal one, which is composed of the twenty-two ideal sounds, and then come the allophones, assuming some form of growth of the linguistic material that becomes language by means of the combination of letters in a manner reminiscent of Joseph Gikatilla's triangle of the linguistic material in the Torah. ${ }^{375}$ Is the transition from these vowels to the consonants of the other divine names and then to regular words an expansion of speech reflecting a vision of the development of speech in humans, from infants to mature adults? ${ }^{376}$

368 Sefer ha-Melammed, 6-7. The versions of this treatise are sometimes problematic. See also below chapter 26 n. 134.

369 Or ha-Śekhel, 92-93.

370 Or ha-Śekhel, 111.

371 For Abulafia's references to his five students from Messina, including Rabbi Nathan and Rabbi Abraham, using theophoric names, see Idel, Kabbalah in Italy, 81-84; cf. Iš Adam in Mașref ha-Śekhel, 46.

372 See Idel, Le Porte della Giustizia, 47-48. For the righteous being called by the Tetragrammaton in Rabbinic texts, see Idel, Ben, 115-17.

373 Or ha-Śekhel, 110.

374 Mafteah ha-Šemot, 163.

375 See my Absorbing Perfections, 360-61.

376 This observation has nothing to do with Abulafia's interpretation of the infant experiment mentioned above. 
In his opinion, the pearl, which is the symbol of the pure religion in Abulafia's special version of the famous three rings parable, was not to be found in Israel during his time. ${ }^{377}$ It follows that Abulafia did not view the mission of Moses, the lawgiver who was conceived as promulgating the perfect and ultimate Torah in Rabbinic circles and in Maimonides, as entirely successful, or at least not final. There is room for a more advanced form of religion, a superior Judaism. ${ }^{378}$ This is the reason why Abulafia imagined that he could bring a new religious revelation. He describes the yet unrevealed divine name as the purest form of language from the linguistic point of view; the supreme reference to God in a religious framework is the real and unknown name of God.

Indeed, in his commentary on his prophetic book, Sefer ha-Haftarah, written around 1282, we find an important passage for clarifying Abulafia's approach. The first-person speaker in the following passage is God-or the Agent Intellect-who reveals to Abulafia that

"A New Torah ${ }^{379}$ I innovate nowadays amongst the holy nation; it is my people Israel, [which is] My sublime Name that is like a New Torah. And it has not been explained to My nation since the day I hid My face from them. And though it is a hidden name, it is explained." ${ }^{380}$ And then He commanded him ${ }^{381}$ to hide His name no more from those who inquire after it in truth, and He revealed it to him according to its holiness, its crowns and its parts and its systems and its forms. And He announced its pronunciation to him, and has shown its customs $\mathrm{s}^{382}$ and also the influxes of life in him, to every spirit. ${ }^{383}$

377 See Idel, The Mystical Experience, 140. This interpretation was accepted by Hames, Like Angels on Jacob's Ladder, 69.

378 Idel, Studies in Ecstatic Kabbalah, 50-51. See also the comparisons of Moses to Rabbi Simon bar Yochai in the following recent studies: Wolfson, Through a Speculum That Shines, 391; Elliot R. Wolfson “'Sage Is Preferable to Prophet': Revisioning Midrashic Imagination," in Scriptural Exegesis-The Shapes of Culture and the Religious Imagination: Essays in Honour of Michael Fishbane, eds. Deborah A. Green and Laura S. Lieber (Oxford: Oxford University Press, 2009): 186-210; Melila Hellner-Eshed, A River Flows from Eden: The Language of Mystical Experience in the Zohar, trans. Nathan Wolski (Palo Alto: Stanford University Press, 2009), 34-36; and Boaz Huss, “'A Sage Is Preferable Than a Prophet': Rabbi Simon Bar Yochai and Moses in the Zohar” [Hebrew], Kabbalah 4 (1999): 103-39.

379 For the concept of New Torah in Abulafia, see Moshe Idel, "Torah Hadashah"-Messiah and the New Torah in Jewish Mysticism and Modern Scholarship," Kabbalah 21 (2010): 70-78. See also chapter 10 above.

380 Namely, revealed.

381 Namely, to Abulafia, who speaks about himself in the third person when he interprets the meaning of the revelations he received.

382 Gross uses מנהיגיו (“its leaders"); I assume that this is a copyist's error.

383 Peruš Sefer ha-Hafțarah, Ms. Roma, Angelica 38, fol. 37a, printed in Mașref ha-Śekhel, 113: כי תורה חדשה אני מחדש בקרב גוי קדוש הוא עמי ישראל, שמי הנכבד כתורה חדשה הוא והוא לא פור פורש לעמי מיום

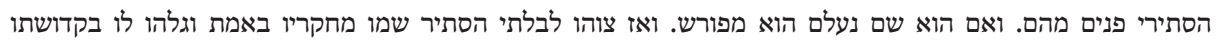

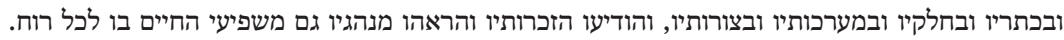

For more on this quote and its implications see Idel, Messianic Mystics, 306-7; Idel, The Mystical Experience, 140-41; and Idel, "Torah Hadashah," 72-73. On the divine name as the quintessence of the esoteric Torah, see the more elaborate discussions of Abulafia's student, Rabbi Joseph Gikatilla, es- 
The Kabbalist is therefore not shy about claiming a final type of revelation. It should be mentioned that in the same book, Abulafia also describes it as Sefer ha-Beśorah, which is the Hebrew equivalent of Evangelion, ${ }^{384}$ and in his commentary on Sefer haHafțarah, Abulafia expects that his book will be read in synagogues after the reading of the Torah, like the portions from the books of the biblical prophets. ${ }^{385}$

Abulafia means that until the revelation that took place around 1280, the hidden name of God-'HWY-was imagined to be unknown by the public, though he himself knew it, and since then, he has been allowed to reveal it and it has come to constitute a new sort of canonical message. This is unquestionably part of the experiences in some months of 1279/80, a year corresponding to the Jewish year 5040, which constituted a turning point in Abulafia's activities, as we shall see in Appendix D.

Let me attempt to analyse the audience for which the revelation is intended. During the previous centuries, the hidden name had been unknown to the nation, but now Abulafia has been sent to reveal it, yet only to those who truly inquire; he has not been sent to reveal it to all the members of the Jewish nation. This distinction seems to me to be quite significant: it leaves most of the Jewish people beyond the frame of the new revelation, and this new audience he concretely envisions was exclusively composed of his own small group of students.

If this distinction between the inquirers and the regular Jews is accepted, we have here a drastic reduction of the nation from a number which normally includes the masses and Rabbis and other Kabbalists as part of an organic unity to a very small elite. This means that Abulafia's Kabbalah, conceived as the quintessence of true Judaism, was supposed to displace the normal Rabbinic type of religion in order to disseminate a practice that was intended only for a few people. To put it in other terms, the ideals of his Kabbalah belong to the axial mode, while the Rabbinic and the theosophical-theurgical Kabbalah belong more to the pre-axial one.

In a way, the hidden nature of the name is reminiscent of the hidden plight of the pearl in the pit, according to the parable that was written in this exact period. This unknown divine name, which is likely the new Torah, is not necessarily a brand new piece of information, but rather a means of fathoming the depth of the biblical text

pecially his famous Ša'arei Orah, which is a text that requires a separate inquiry. It seems that Abulafia approximates the triangular structure of Gikatilla's vision of the words in the Torah with a divine name at the top, then ten divine names, and then seventy cognomens; at the base of the triangle are all the other words in his various writings, especially in Or ha-Śekhel, 72-73. While the hidden name, or in other cases the Tetragrammaton, is at the top of a pyramid (or triangle), Abulafia's combinations of the letters of the divine names that constitute his mystical techniques have a lower status than it; in this way, all the other words of the text of the Hebrew Bible are even lower, each series of words depending on the higher ones. See Idel, Absorbing Perfections, 360-67.

384 See Idel, Messianic Mystics, 108.

385 See his Commentary on Sefer ha-Hafțarah, in Mașref ha-Śekhel, 107:

הנה צוה רזיאל בזה הספר להשביע עם יי' בשמו לקדשו ולקרא ספר זה בכל שבת פעם אחת אחר קריאת התורה בכלל 
by resorting to the Kabbalistic techniques that Abulafia advanced. These techniques consist in finding out the secret, still unrevealed divine name by combining the consonants of two other divine names. These two layers are assumed to coexist in the Bible, but are intended for quite different audiences: the esoteric sense is intended solely for the elite and the plain sense for the masses.

Gaining access to the esoteric layer is, according to Abulafia, tantamount to a form of redemption, which in his terms means a personal and intellectual salvation. It should be mentioned that the revelation of a new name for God to a messianic figure like Abulafia is reminiscent of the revelation of the name 'eHeYeH to Moses, described as previously unknown in Exodus 3:14. ${ }^{386}$ Implicitly, this disclosure of the unknown name constitutes a higher, if not supreme form of revelation in Abulafia's way of thought and plausibly situates him in his self-portrayal as the seal of all the prophets.

In short, among the main contents of Abulafia's Kabbalah that contributed to the earlier forms of this literature, there are exegetical techniques and divine names conceived as representing the secret layers of the Torah, the New Torah, and the new revelation on the one hand and as the means of redemption on the other. The coexistence of the normal, plain sense of the Torah that is understood as maintaining normal social life and the esoteric sense that has, for the few, a salvific dimension in the present, although it is ultimately conceived as a matter for the future, is a situation that I would call synchrony. ${ }^{387}$ This synchrony hosts two diverging approaches concomitantly, which are reflected by the terms that are hidden and revealed. In other words, the two quite different registers are not exclusive, though for this Kabbalist, the present experience, related to the salvific dimension, is much more important.

This seems to me to be the case when Abulafia describes the future state of things. In a way, this is a self-referential statement, as it deals with the revelation of the divine name:

In the future [...] all the three [nations] ${ }^{388}$ will know God by name, as it is said: "For then I shall turn to the people a pure language that they may all call upon the name of the Lord." ${ }^{389}$ The

386 See Idel, The Mystical Experience, 140.

387 See Idel, “Abraham Abulafia: A Kabbalist 'Son of God,"” 62-64. My assumption as to synchrony in Abulafia hardly fits a vision that is comparable to the Joachimites' theory that there are three distinct phases in the development of history, the last one being the most spiritual and related to the Holy Spirit. Nor do his writings display an interest in the ideal of poverty that is so conspicuous among the fraticelli.

388 Namely, the three monotheistic religions. Nota bene: the three nations are understood as one conceptual unit and the Messiah implicitly transcends the Mosaic revelation.

389 Zefania 3:9. This is an important proof-text for Abulafia’s theory. See also his Sefer Šomer Miṣwah, 40. 
great wisdom of the redeemer ${ }^{390}$ shall be the cause of this knowledge. Of him, it was said: ${ }^{391}$ "Behold, my servant shall deal prudently, he shall be exalted and excellent, and shall be very high." In the tradition [qabbalah], it was said: "He shall be more exalted than Moses, and more extolled than Abraham, and higher than the ministering angels-greater than any man. ${ }^{392}$

The assumption is that all religions or nations will know the divine name, a fact that minimises the centrality of the Jewish people in the eschatological scenario. The assumption that the Messiah has a higher status than Moses also has to do with another important topic: the enormous gap between Abulafia's view that the Torah essentially possesses a paramount esoteric layer that is sometimes even envisioned as contradicting the plain sense on the one hand and that espoused by his Rabbinic contemporaries as dealing with laws and parables on the other. This assumption brought him to the conclusion that the Torah in its purity is not yet to be found in the hands of the people of Israel, but will be revealed in its entirety only during the Messianic era; until then, it may only be for the few elites in the present to whom he revealed it.

In Abulafia's parable, it is indicated that the unique pearl, which symbolises the true religion, is not to be identified with any of the present historical religions. Indeed, though the nation of Israel has a natural priority for receiving it, in that they are the "son" of God, they have not yet received it, as the son angered his father and is portrayed as being devoid of knowledge. ${ }^{393}$ I would say that just as the potential intellect has the propensity to receive the actualised intellect but is yet still sunk in matter, desire, or imagination, in principle, the Jews are more capable of receiving the new Torah or the knowledge of the divine name than the servants. This claim presumably allegorically points to the other historical religions according to the historical narrative and to lower human capacities according to the transhistorical one. In my opinion, these lower capacities also include the imaginative faculty. It should be mentioned that the plural form of pearl, margaliyyot, possesses an esoteric meaning on some occasions in Abulafia's writings. ${ }^{394}$ This esoteric meaning reinforces the possibility that Abulafia is referring to an esoteric religion in the parable.

390 . חכמת הגואל. On this phrase, which occurs many years beforehand, though in a different sense, in Abulafia's commentary on Sefer ha-Yašar, see the detailed analysis in Idel, Messianic Mystics, 298301.

391 Isaiah 52:13.

392 Mafteah ha-Šemot, Ms. New York, JTS 843, fol. 68b, ed. Gross (Jerusalem: 2001), 81-82:

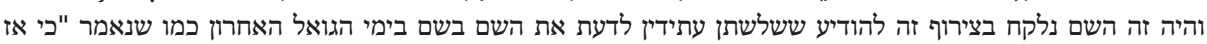

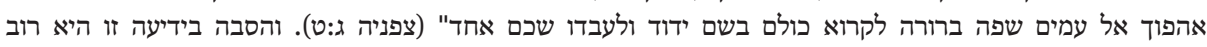

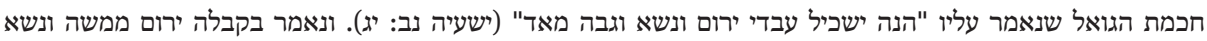

מאברהם וגבה ממלאכי השרת מאד מכל אדם.

For the earlier sources of Abulafia's discussion, see Idel, Studies in Ecstatic Kabbalah, 50-51; Idel, The Mystical Experience, 140-41; and Idel, Ben, 323.

393 See Idel, Language, Torah, and Hermeneutics, 75.

394 See Abulafia, Geț ha-Šemot, 40; Abulafia, Ḥayyei ha-Nefeš, 128; and his Untitled Treatise, Ms. Firenze, Laurenziana, Plut. II. 48, fol. 81a. 
This emphasis on intellectual redemption means that the type of eschaton he describes is not specifically a matter of the remote or immediate future, which is dependent on a historical redemptive figure, but is rather a psychological process that can be achieved by a few individuals even in the present, either alone or in a small circle. The assumption of a "hidden" intellect shows that the potential for present redemption is already found in the past in a manner reminiscent of Averroes's specific theory of the cleaving to the separate intellect and the basic identity of the material and active intellect. It is not a matter of an event that is to occur in the eschatological future alone, but also in the ideal present. This more spiritual reading of philosophy differs from the Straussian emphasis on the esoteric social focus, though in the case of Abulafia's ecstatic religion, they are found together. ${ }^{395}$

In any case, the emphasis in recent scholarship on Abulafia on the role of imagination as an allegedly positive factor in this Kabbalist's gnoseology and as a human faculty to be "integrated" into a higher form of existence or experience is, in my opinion, quite problematic to say the least, especially if one undertakes a serious perusal of the pages of his Or ha-Śekhel ${ }^{396}$ as well as some of his other books. ${ }^{397}$ These scholars' assumption is conditioned by an implicit supposition about the maintenance of some form of identity of the various nations in the historical narrative in the eschaton or of the lower human spiritual capacities in the highest type of utopian experience according to the transhistorical narrative. My assumption is that in Abulafia's

395 For the awareness of the possibility of exploiting the spiritual potentialities of Greek theories of cognition, see the pioneering study by Merlan, Monopsychism, Mysticism, Metaconsciousness; Pierre Hadot, Qu'est-ce que la philosophie antique? (Paris: Gallimard, 1995); Pierre Hadot, Exercices spirituels et philosophie antique (Paris: Institut d'études augustiniennes, 1993); Pierre Hadot, "Exercices spirituels," Annuaire de la $V^{e}$ section de l'École pratique des hautes études 84 (1974): 25-70; Richard T. Wallis, "Nous as Experience," in The Significance of Neoplatonism, ed. R. Baine Harris (Norkfold: SUNY Press, 1976): 122 and 143, note 1; and Terry Lovat and Inna Semetsky, "Practical Mysticism and Deleuze's Ontology of the Virtual," Cosmos and History: The Journal of Natural and Social Philosophy 5, no. 2 (2009): 237. For a similar approach applied to Maimonides, who is understood as a mystic to a certain extent, see Georges Vajda, Introduction à la pensée juive du moyen age (Paris: Vrin, 1947), 143-44; Blumenthal, Philosophic Mysticism; Stern, The Matter and Form of Maimonides' Guide; Joseph B. Sermoneta, "Rabbi Judah and Immanuel of Rome”; Faur, Homo Mysticus; Lorberbaum, Dazzled by Beauty, 15-55, especially 32-33 (in French, "Mystique mythique et mystique rationelle”). See also Bernd Raditke, "How Can Man Reach Mystical Union? Ibn Tufayl and the Divine Spark," in The World of Ibn Tufayl, 165-94.

396 See Abraham Abulafia, 80-85. Wolfson's approach-and, following him, Sagerman's approachassumes the importance of a theory of the integration of the lower faculties, especially imagination, in Abulafia's higher experience, as well as in theosophical Kabbalah in general. For the latter, see his The Serpent Kills, 11, 187, 190-91, 193, 235, 253, 255, 321, etc. However, this assumption is not reflected, in my opinion, in Abulafia's material, which we have presented here, concerning the ideal type of experience; namely, the noetic union of the human intellect with the divinity or with the Agent Intellect. I hope to dedicate a separate study to the status of the faculty of imagination in Abulafia's thought and its sources. See, meanwhile, Faur, Homo Mysticus, 11, and Stern, The Matter and Form of Maimonides' Guide.

397 See the texts discussed in Idel, The Mystical Experience, 99-100. 
eyes, and according to the third narrative, the highest experience is one of universalisation, which also means spiritual simplification, and depersonalisation, which effaces differences; this, I would claim, is also what is at work in the second narrative.

When dealing with the highest religious experience, we would do better to speak about the disintegration of the complex human personality, compounded as it is of higher and lower faculties, through what he calls "untying the knots"398 in several of his discussions. These knots stand for the attachments of the soul or the intellect ${ }^{399}$ to the material world or the faculty of imagination; untying these binds leads to the human aggregate being reduced to the intellectual faculty alone, a process I propose to call intellectual simplification. We shall revert to the issue of untying the knot in chapter 26 below.

The human intellectual faculty is understood to be capable of cleaving to God, an entity described in many cases in Abulafia's writings as "simple," pašuț, in a manner in which the impact of many other medieval sources, including Maimonides, ${ }^{400}$ Avicenna, and perhaps also Averroes, may be discerned. ${ }^{401}$ Indeed, in an enigmatic statement, Abulafia declares that there is a great secret that he cannot reveal to flesh and blood and that this secret has to do with the divine causes: "The simplest among them is also compounded of all, and the most compounded of them is the simplest." 402

\section{Abraham Abulafia: Was He the Possessor of the Pearl?}

It seems that Abulafia purposefully adopted a version of the parable on the true religion that differed in its articulation from the one which was more widespread in Europe. In the above parable, there is only one son, not three; there are not three rings, but only one single "authentic" pearl; and finally, there is no mention of additional artefacts, rings or pearls. However, even more divergent than the details of the parable in comparison to most of the other extant versions is the specific mystical framework, as discussed above, which is more sophisticated than anything I am acquainted with in the interpretations that have been offered of other versions of the parable. The peak of this sophistication is, in my opinion, to be found in the implicit assumption that the real son in the parable is none other than Abraham Abulafia himself, and that the pearl is in the possession of the teller of the parable; namely, that Abulafia alone possesses it.

398 See Idel, The Mystical Experience, 134-37.

399 For the understanding that the soul is in fact the intellectual faculty, see Or ha-Śekhel, 121. 400 Guide 1:60, Pines, 1:146-47.

401 See Barry S. Kogan, Averroes and the Metaphysics of Causation (Albany, NY: SUNY Press, 1985), $238-40$.

402 See Abulafia’s text found anonymously in Ms. Sasoon 290, 235-36. See also Wolfson, "Kenotic Overflow and Temporal Transcendence,” 170, note 150. 
If this identification is correct, here the present and future are colliding in a situation that is, in Abulafia's opinion, moving rapidly towards a more general redemption according to the second narrative, ${ }^{403}$ though he himself may be imagined as already being redeemed because of the revelations he claims to have previously received. In any case, since the hidden divine name had already been revealed some years earlier, now everyone may redeem themselves by using it.

The eschatological content of Abulafia's prophetic books, dealing as they do with revelations he received while he was in Greece around 1279 and in Italy in 1280, and the commentaries he wrote on those books in Messina in 1282, whose original versions have been lost, points to a situation like the father bringing the pearl out of the pit and his giving it to the son. In both cases, the revelation of the previously unknown divine name is an event that plays a central eschatological role. May we assume that the pit is none other than the imaginative casting of the historical religions?

Moreover, Abulafia conceives himself as an intellectual son of God and as a prophet in addition to being a Messiah. ${ }^{404}$ Thus, he imagines that he possesses some of the attributes he ascribes to the son in the parable. It should be emphasised that my proposal to read the parable in an allegorical manner and not only in a historical one is part of a broader understanding of Abulafia's general project that is intended to spiritualise the interpreted text, as mentioned above, which makes it much more plausible. This is obvious, for example, in the case of Abulafia's spiritual interpretation of messianism alongside and against how it was understood in popular Judaism; he intended to trigger a spiritual revivification. ${ }^{405}$ As seen in the case of his understanding of messianism, Abulafia proposes three different meanings of the term "Messiah," and this is also the case for his understanding of the nature of the Jews as those individuals who confess the divine name and the understanding of Israel as being related to both the Agent Intellect and the combination of letters. ${ }^{406}$

All of these issues are major topics in Abulafia's religious worldview, and in these cases, the allegorical interpretations that he offered constituted a fresh, explicit understanding of important subject matters that had only been accepted in their concrete sense by generations of Rabbinic Jews. Abulafia does continue the path of allegorisation that was opened in Judaism in large part by Maimonides's Guide, which was especially concerned with purifying the biblical language from formulations that are problematic from the theological point of view, especially expressions that refer

403 For the emphasis on the second narrative as being related to "universal salvation," see Hames, Like Angels on Jacob's Ladder, 54-70.

404 See Idel, Ben, 310-11, 316, and Idel, “Abraham Abulafia: A Kabbalist 'Son of God.”

405 See Idel, "The Time of the End."

406 See Idel, “Abraham Abulafia: A Kabbalist 'Son of God,” 64-68, 78; Idel, "The Time of the End,” 172; Idel, "On the Secrets of the Torah in Abraham Abulafia," 433-34; Idel, Kabbalah in Italy, 84-88. 
to anthropomorphisms and anthropopathisms. ${ }^{407}$ However, he goes further by combining Maimonides's allegorisations with linguistic mysticism as part of his exegesis of sacred scriptures with an attempt to understand and explain his own experiences through the use of two exegetical methods. He was much less concerned with issues related to cosmology or even with detailed theories of the intellect than the Great Eagle and Averroes were.

407 See Isaac Heinemann, "Die wissenschaftliche Allegoristik des jüdischen Mittelalters," HUCA 23, no. 1 (1950/51): 611-43; Warren Zev Harvey, “On Maimonides' Allegorical Reading of Scripture," in Interpretation and Allegory: Antiquity to the Modern Period, ed. Jon Whitman (Leiden: Brill, 2000): 18188; Samuel M. Stern, "Rationalists and Kabbalists in Medieval Allegory," JJS 6 (1955): 73-86; Sara Klein-Braslavy, Maimonides's Interpretation of the Adam Stories in Genesis; Simon Rawidowicz, "On Interpretation," PAAJR 26 (1957): 97-100; Frank Talmage, "Apples of Gold: The Inner Meaning of Sacred Texts in Medieval Judaism," in Jewish Spirituality from the Bible through the Middle Ages, ed. Arthur Green (New York: Crossroad, 1986): 318-21; Shalom Rosenberg, "Observations on the Interpretation of the Bible and Aggadah in the Guide of the Perplexed" [Hebrew], in Memorial Volume to Ya'aqov Friedman, ed. Shlomo Pines (Jerusalem: Hebrew University, 1974): 215-22; Jean Robelin, Mä̈monide et le langage religieux (Paris: Presses Universitaires de France, 1991); Arthur Hyman, "Maimonides on Religious Language,” in Perspectives in Maimonides: Philosophical and Historical Studies, ed. Joel Kraemer (Oxford: Littman Library of Jewish Civilization, 1991): 175-91; Maurizio Mottolese, Analogy in Midrash and Kabbalah: Interpretive Projections on the Sanctuary and Ritual (Los Angeles: Cherub Press, 2007), 247-67; Marc Saperstein, "The Earliest Commentary on the Midrash Rabbah," in Studies in Medieval Jewish History and Literature, 1:283-306; Marc Saperstein, "R. Isaac ben Yeda'ya: A Forgotten Commentator on the Aggada,"” REJ 138 (1979): 17-45; Saperstein, Decoding the Rabbis; Howard Kreisel, "The Philosophical-Allegorical Exegesis of Scripture in the Middle Ages: Ma'aśeh Nissim by Rabbi Nissim of Marseilles" [Hebrew], in Me'ah She'arim, 297-316; and Hannah Kasher, "The Myth of the 'Angry God' in the Guide of the Perplexed" [Hebrew], in Myth in Judaism, ed. Haviva Pedaya (BeerSheva: Ben-Gurion University Press, 1996): 95-111. 